Waterways Experiment

Station

\title{
Numerical Model Study of Breakwaters at Grand Isle, Louisiana
}

by Mark B. Gravens, Julie Dean Rosati

Approved For Public Release; Distribution Is Unlimited 
The contents of this report are not to be used for advertising, publication, or promotional purposes. Citation of trade names does not constitute an official endorsement or approval of the use of such commercial products. 


\section{Numerical Model Study of Breakwaters at Grand Isle, Louisiana}

by Mark B. Gravens, Julie Dean Rosati

U.S. Army Corps of Engineers

Waterways Experiment Station

3909 Halls Ferry Road

Vicksburg, MS 39180-6199

Final report

Approved for public release; distribution is unlimited

Prepared for U.S. Army Engineer District, New Orleans

Foot of Prytania St.

P.O. Box 60267

New Orleans, LA 70160-0267 


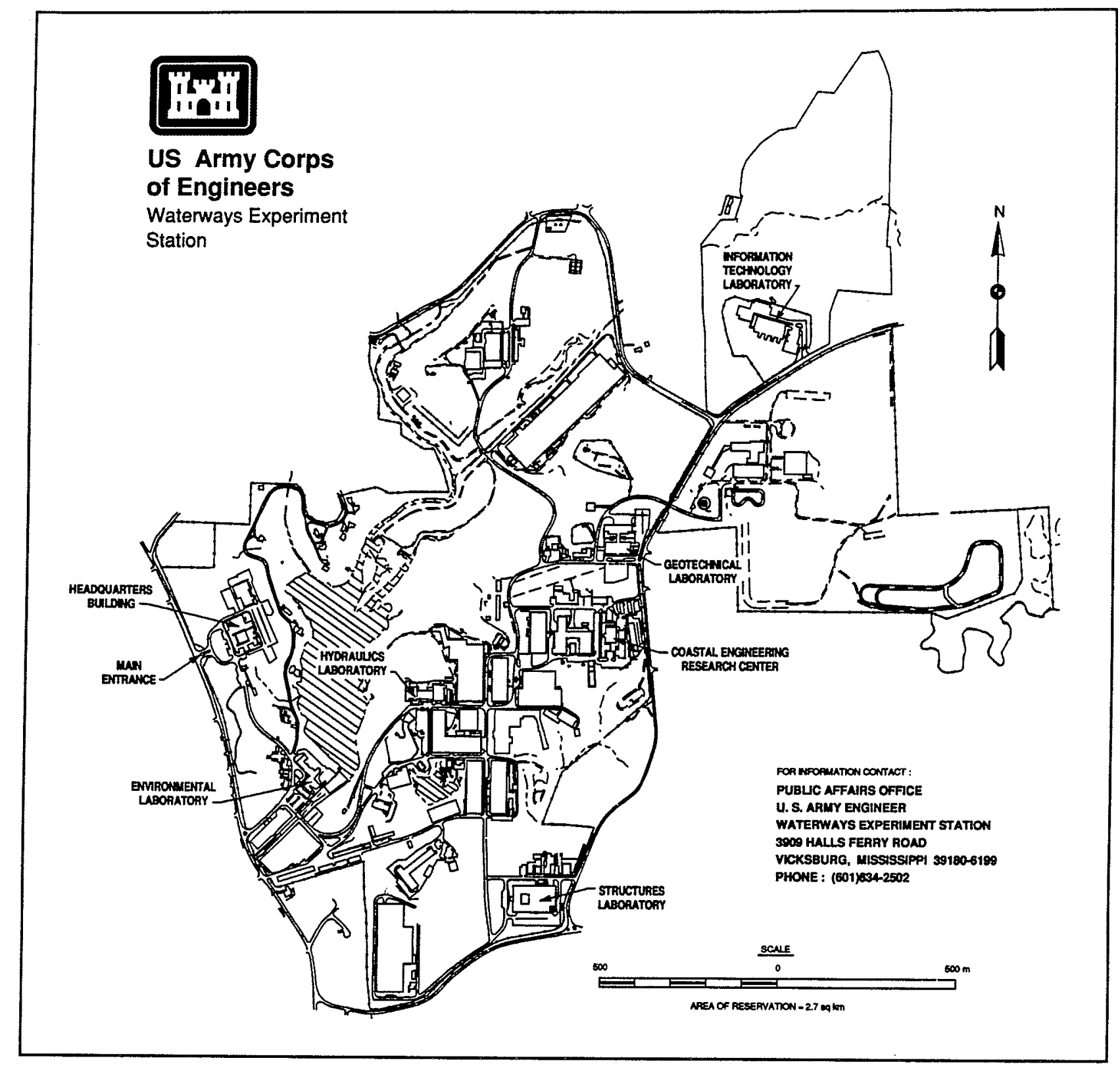

\section{Waterways Experiment Station Cataloging-in-Publication Data}

Gravens, Mark B.

Numerical model study of breakwaters at Grand Isle, Louisiana / by

Mark B. Gravens, Julie Dean Rosati ; prepared for U.S. Army Engineer

District, New Orleans.

81 p. : ill. ; $28 \mathrm{~cm}$. - (Miscellaneous paper ; CERC-94-16)

Includes bibliographic references.

1. Breakwaters - Louisiana - Grand Isle. 2. Ocean circulation -

Mathematical models. 3. Breakwaters - Design and construction -

Evaluation. 4. Beach erosion - Louisiana - Grand Isle. I. Rosati, Julie

Dean. II. United States. Army. Corps of Engineers. New Orleans District.

III. U.S. Army Engineer Waterways Experiment Station. IV. Coastal

Engineering Research Center (U.S.) V. Title. VI. Series: Miscellaneous paper (U.S. Army Engineer Waterways Experiment Station);

CERC-94-16.

TA7 W34m no.CERC-94-16 


\section{Contents}

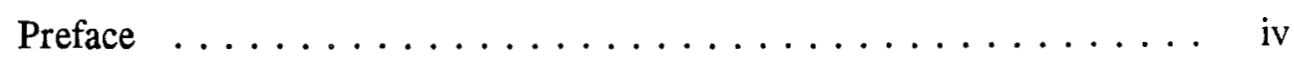

Conversion Factors, Non-SI to SI Units of Measurement $\ldots \ldots \ldots \ldots$ v

1 -Introduction $\ldots \ldots \ldots \ldots \ldots \ldots \ldots \ldots \ldots \ldots \ldots \ldots$

Scope of Work . . . . . . . . . . . . . . 1

Organization of this Report $\ldots \ldots \ldots \ldots \ldots \ldots \ldots \ldots$

Historical and Existing Conditions $\ldots \ldots \ldots \ldots \ldots \ldots$

2-Wave Refraction Analysis $\ldots \ldots \ldots \ldots \ldots \ldots \ldots$

Wave Hindcast $\ldots \ldots \ldots \ldots \ldots \ldots \ldots \ldots \ldots \ldots$

Nearshore Wave Transformation Simulation $\ldots \ldots \ldots \ldots \ldots 12$

3-Long-term Shoreline Change $\ldots \ldots \ldots \ldots \ldots \ldots \ldots .17$

Introduction . . . . . . . . . . . . . . . 17

Shoreline Change Model GENESIS $\ldots \ldots \ldots \ldots \ldots \ldots \ldots$

Model Calibration and Verification ............... 26

Evaluation of Alternative Breakwater Configurations . . . . . . 34

4-Empirical Analysis of Breakwater Design . . . . . . . . . . 61

Overview ........................ 61

Louisiana Breakwater Projects . . . . . . . . . . . . . . . 61

Empirical Predictions of D1 and Louisiana Breakwater Project

Response . . . . . . . . . . . . . . . 65

Comparison with Projects in Similar Environments $\ldots \ldots \ldots \ldots 67$

5-Summary and Recommendations $\ldots \ldots \ldots \ldots \ldots \ldots \ldots$

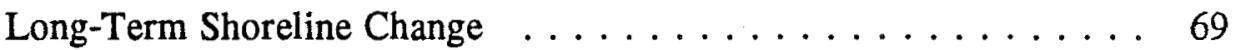

Empirical Analysis of Breakwater Design . . . . . . . . . . 70

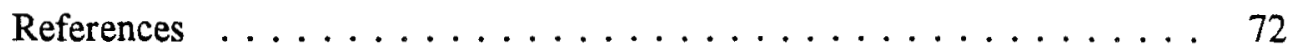




\section{Preface}

The numerical model study reported herein was requested by the U.S. Army Engineer District, New Orleans (LMN), as part of the comprehensive Grand Isle, Louisiana and Vicinity, Hurricane Protection Project. This investigation was conducted by personnel of the U.S. Army Engineer Waterways Experiment Station (WES) Coastal Engineering Research Center (CERC), during the period November 1992 to December 1993. Mr. Jay Combe was the LMN Technical Monitor for this study.

This report presents the results of a numerical shoreline response investigation of a proposed segmented detached breakwater project offshore of Grand Isle, Louisiana. The functional shore protection characteristics of the recommended breakwater design alternative are further evaluated using empirical methods together with comparison to a recently constructed breakwater project between Holly Beach and Ocean View Beach in Cameron Parish, Louisiana. The investigation involved three interrelated technical tasks: (a) nearshore wave transformation, (b) numerical modeling of shoreline response, and (c) comparison of proposed breakwater design with empirical functional design guidance and similar projects. Mr. Mark B. Gravens, Coastal Processes Branch (CPB), Research Division (RD), CERC, was Principal Investigator for this project, conducted the numerical analysis tasks, and authored the sections of the report pertinent to those areas. Ms. Julie Dean Rosati, CPB, performed the functional design analysis and comparison with the Cameron Parish breakwater project and authored the section of the report that deals with those areas.

This study was conducted under the administrative supervision of Dr. James R. Houston, Director, CERC; Mr. Charles C. Calhoun, Jr., Assistant Director, CERC; Mr. H. Lee Butler, Chief, RD, CERC; and Mr. Bruce A. Ebersole, Chief, CPB, CERC.

At the time of publication of this report, Director of WES was Dr. Robert W. Whalin. Commander was COL Bruce K. Howard, EN. 


\section{Conversion Factors, Non-SI to SI Units of Measurement}

Non-SI units of measurement used in this report can be converted to SI units as follows:

\begin{tabular}{|l|l|l|}
\hline Multiply & By & To Obtain \\
\hline cubic yards & 0.7646 & cubic meters \\
\hline feet & 0.3048 & meters \\
\hline miles (U.S. statute) & 1.6093 & kilometers \\
\hline pounds (moss) & 0.4535924 & kilograms \\
\hline \hline
\end{tabular}




\section{Introduction}

The U.S. Army Engineer Waterways Experiment Station (CEWES), Coastal Engineering Research Center (CERC), was requested to provide technical assistance to the U.S. Army Engineer District, New Orleans (LMN), in an engineering study of coastal processes related to the influence of a series of segmented detached breakwaters on future shoreline evolution along the Gulf of Mexico coast of Grand Isle, Louisiana. The study was funded through two DD Form 448 "Military Interdepartmental Purchase Request" dated 10 November 1992 and 3 June 1993.

\section{Scope of Work}

The purpose of the study was to interpret data to assist in the evaluation and implementation of LMN's shore protection plan involving the construction of segmented detached breakwaters offshore of Grand Isle. The influence of nine different breakwater configurations on future shoreline evolution was initially investigated. Subsequent to this analysis, shoreline response to three additional configurations was simulated, for a total of twelve detached breakwater system configurations evaluated.

The technical portions of this study were accomplished through three interrelated tasks. The individual tasks are:

a. Task 1: Nearshore wave transformation study.

b. Task 2: Numerical modeling of shoreline response.

c. Task 3: Comparison of proposed breakwater design with empirical functional design guidance and similar projects.

The procedures and methodologies used to perform these tasks together with the final results are presented in this report.

The nearshore wave transformation study (Task 1) included performing a spectral transformation of the 20 -year-long record of wave information, 
obtained at WIS Gulf of Mexico Hindcast Station 21, from the hindcast station water depth of approximately $300 \mathrm{ft}^{1}$ to a water depth of $40 \mathrm{ft}$. Next, the 20 -year-long record of wave information was statistically analyzed and 22 representative classes of offshore wave period-direction conditions were identified. These 22 classes of incident wave conditions were then numerically transformed across a digitized nearshore bathymetry extending from the 40-ft contour to the Grand Isle shoreline and from Caminada Pass to Barataria Pass alongshore. Results of the task provided reference nearshore wave information required for input to the shoreline evolution model, wave refraction and shoaling coefficients, together with incident wave angles along a nearshore reference line located just seaward of predominant wave breaking (approximately following the $14 \mathrm{ft}$ contour line).

Task 2, numerical modeling of long-term shoreline response, involved the application of the shoreline change numerical model GENESIS, in which longshore sand transport and the accompanying shoreline change are primarily driven by the nearshore wave information produced in Task 1. The GENESIS model was calibrated and verified for Grand Isle using a statistically representative time series of offshore wave conditions, a database of nearshore wave information, and historical shoreline positions obtained from aerial photographs. The calibrated model was then used to estimate shoreline response to the implementation of the twelve different segmented detached breakwater configurations. After determining equilibrium beach responses to the breakwaters, the model was again employed to estimate beach fill maintenance quantities necessary to maintain the shoreline downdrift of the breakwater project.

Task 3 involved comparison of the shoreline response predicted for the breakwater design that provided protection to the project area while minimizing adverse effects on adjacent beaches using GENESIS with that predicted by empirical functional design guidance, and the performance of similar detached breakwater projects. This task was performed as a check on the results of the numerical shoreline response modeling and utilizes procedures for estimating the functional performance of breakwaters on shoreline change. Currently, empirical methods represent the only available tools for estimating shoreline response to detached breakwaters in the absence of using a numerical shoreline change simulation model such as GENESIS. Traditional methods for designing the configuration of a series of detached breakwaters include use of empirical methods together with experiences gained from similar projects. If resources are available, physical models can be used to intercompare various detached breakwater designs. Oftentimes the construction of prototype test structures is recommended to obtain an understanding of the influence of breakwaters at a specific site prior to implementation of a complete breakwater project. Fortunately, a similarly

\footnotetext{
1 A table of factors for converting non-SI units of measurement to SI units is presented on page $v$.
} 
configured breakwater project was recently constructed in Cameron Parish in the western part of Louisiana and provides a model for designing a breakwater project at Grand Isle. This task reviewed the observed morphological response at the Cameron Parish project and made comparisons to the proposed project at Grand Isle.

\section{Organization of this Report}

This report is divided into 5 Chapters. Chapter 1 describes the purpose of the study, summarizes the scope of the investigation, and gives an introductory orientation to the study area and the observed coastal processes along the Grand Isle shoreline. Chapters 2 through 4 present the methodologies and procedures employed together with the final results of the 3 individual study tasks. Chapter 5 provides a summary of the findings of the entire study and recommends the segmented detached breakwater and beach fill configuration estimated to provide sufficient protection to the project beach while minimizing adverse impacts on adjacent beaches.

\section{Historical and Existing Conditions}

This section reviews previous work to provide a summary of independent assessments of the predominant coastal processes and data pertinent to the study. Important sources of supplementary information are identified, and an orientation to the study area is given.

\section{Orientation to the study area}

Grand Isle is located on the Gulf of Mexico in Jefferson Parish, Louisiana (Figure 1), and is about 60 miles south of New Orleans and 45 miles northwest of the Southwest Pass of the Mississippi River. Grand Isle is part of the Bayou Lafourche barrier system which forms the seaward geologic framework of the eastern Terrebonne and western Barataria basins in Terrebonne, Lafourche, and Jefferson parishes (Penland et al. 1992). This system consists of Timbalier Island, East Timbalier Island, the CaminadaMoreau Headland, Caillou Island, and Grand Isle. Grand Isle is a laterallymigrating flanking barrier island built by recurved spit processes.

Flanking barrier islands typically are formed through a series of processes that includes recurved spit building, longshore spit extension, subsequent hurricane impact and breaching, and island formation. The morphology of Grand Isle reflects the geomorphic imprint of the recurved spit process. Penland et al. 1992 in their study of shoreline change between 1887 and 1978 in this region, state that the history of the Bayou Lafourche barrier system illustrates erosion of the central headland (Caminada-Moreau Headland) with concurrent development and lateral migration of the flanking barrier islands. 


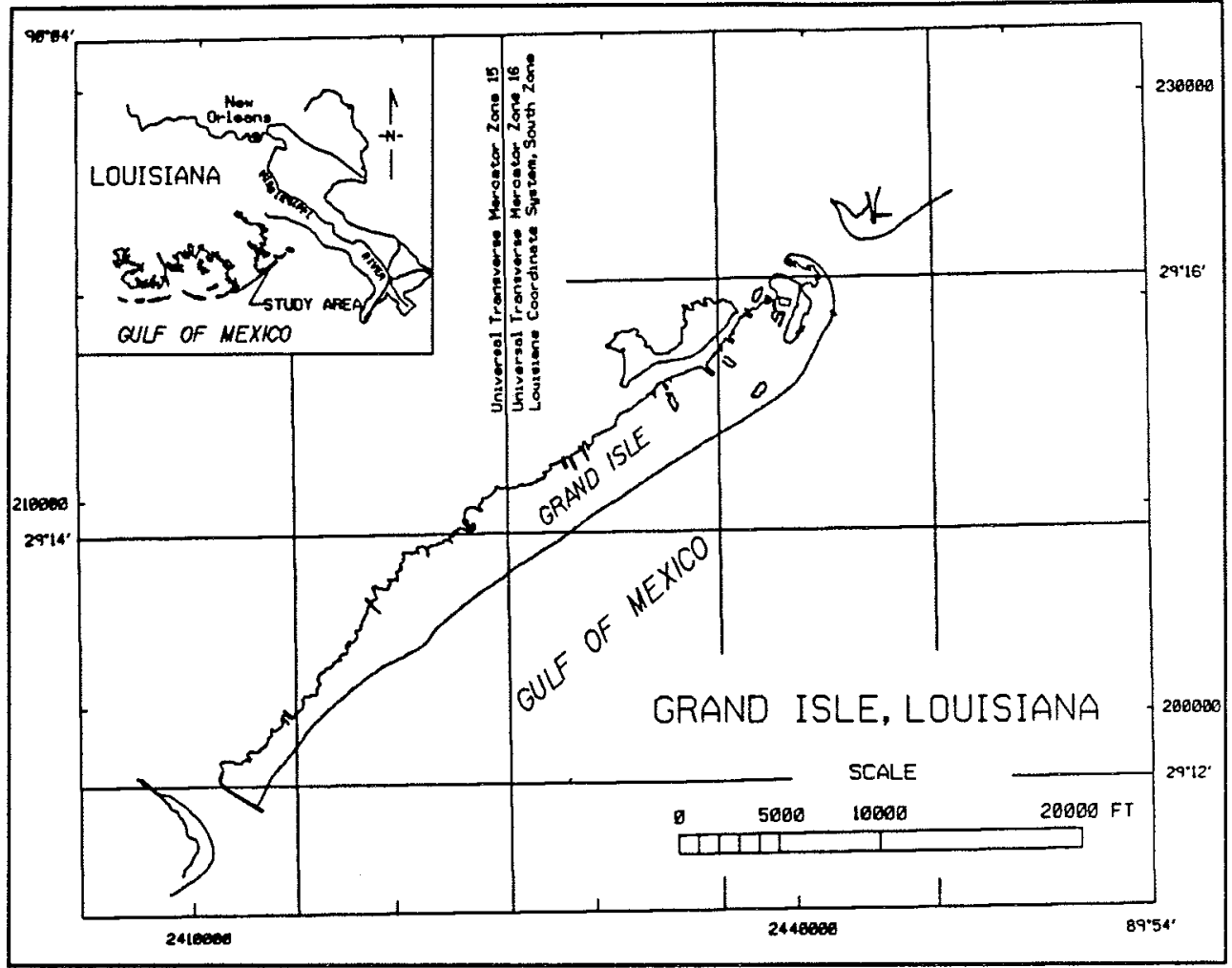

Figure 1. Grand Isle vicinity map

Grand Isle is a classic drumstick-shaped barrier island with a narrow western end that widens to the east and becomes bulbous on the eastern end (McBride et al. 1992). Grand Isle is the only barrier island in Louisiana that is commercially and residentially developed (Meyer-Arendt 1987) and is therefore one of the most important barrier islands off the coast of Louisiana from an economic and political standpoint.

Grand Isle is in general, low-lying with center island elevations ranging between 3 and $5 \mathrm{ft}$ above National Geodetic Vertical Datum (NGVD). The island is approximately 7.5 miles long, 0.75 miles wide, and is oriented in a northeast to southwest direction. To the east is Barataria Pass, the deepest tidal inlet along the Louisiana coastline, and further to the east is Grand Terre Island. To the west is Caminada Pass and the Cadinada-Moreau headland. The only connection between the island and the mainland is the Louisiana Highway 1 bridge.

The long-term evolution of Grand Isle is characterized by both shoreline advance and retreat along the gulfward shoreline. For the island as a whole, the shoreline retreated at a rate of approximately $3 \mathrm{ft} /$ year between 1887 and 1934 (McBride et al. 1992). For the periods 1934 to 1956, 1956 to 1978, and 1978 to 1988 , the average shoreline change was either stable or slightly advancing gulfward. Shoreline change rates for these periods have been estimated (McBride et al. 1992) at $0 \mathrm{ft} /$ year, $8 \mathrm{ft} /$ year, and $17 \mathrm{ft} /$ year, 
respectively. Examining shoreline change along the island for this 101-year period shows that the shoreline has experienced retreat along its western end, remained relatively stationary at its midsection, and accreted on its eastern end. These trends indicate that Grand Isle is slowly rotating clockwise around a stable midpoint.

The gulfward shoreline of Grand Isle has historically exhibited rapid movement in response to natural and human forces. The unconsolidated beach sediments composing the Grand Isle shoreline respond almost instantly to winter storms and hurricanes (U.S. Army Corps of Engineers 1979) and more gradually to normal wave and current processes and relative sea level fluctuations. Human activities that have influenced shoreline change along Grand Isle include the construction of groins, jetties, beach fills, dunes, and nearshore dredging. Since 1954, in excess of 2 million $\mathrm{yd}^{3}$ of material have been placed on the beach in efforts to restore it and to stabilize problem areas. These beach fills have contributed significantly to the overall shoreline advance discussed previously.

More recently, the western end of the island appears to have been stabilized, at least to some extent, by the construction of a $2,600 \mathrm{ft}$ revetment and jetty system around the western end of the island. Construction of this jetty system was completed in July 1972, and was performed as an emergency effort by the Louisiana Department of Public Works to halt critical erosion occurring in this region of the island. Between March 1968 and May 1971 approximately 35 acres of land was eroded in this region (U.S. Army Corps of Engineers 1979). Recent landward retreat of the shoreline along Grand Isle appears to be dominated primarily by storm events, particularly hurricanes, which impact the exposed gulfward shoreline frequently. These events cause widespread flooding and damage by the penetration of storm surges inland across the island. In the past the island has flooded from both the gulf and bay sides depending on the track of the particular storm. Large waves associated with these hurricanes remove large quantities of sand from the beach face and deposit it offshore or carry the material over the dune and deposit it landward of Highway 1.

\section{Previous studies}

Long-term historical shoreline change between 1887 and 1988 along Grand Isle has been documented by Williams et al. 1992. Their study investigated bayside shoreline change, barrier island width changes, and island area changes in addition to gulfside shoreline change. The study includes a geomorphic description of the island including its formation, and evolution, together with a historical account of development on the island. This document contains similar information for the entire Louisiana coastal shoreline. 
The most comprehensive study of Grand Isle is the 1979 U.S. Army Corps of Engineers report on Grand Isle. This report contains extensive information on coastal erosion, coastal processes, and sand resources, and designs for the Corps of Engineers beach erosion and hurricane protection project which was built in 1984 . Combe and Soileau (1987) reported on construction details and the successful performance of this project during and after the unusual 1985 hurricane season in which Hurricanes Danny, Elena, and Juan impacted the island.

A report related to this investigation of proposed breakwaters at Grand Isle was prepared by engineering firm HNTB under contract for the Louisiana Department of Natural Resources, Coastal Restoration Division (1993). This report reviews Louisiana State Senate Concurrent Resolution Number 83, which urges the Wetlands Conservation and Restoration Authority, the Department of Transportation and Development, and the U.S. Army Corps of Engineers to examine the feasibility and advisability of placing breakwater protection along the coast of Grand Isle, Louisiana. The report provides a good summary of coastal projects constructed at Grand Isle between 1951 and 1991, reviews the performance of the breakwater project at Holly Beach, Louisiana, and proposes a conceptual segmented detached breakwater project design and layout for Grand Isle. 


\section{Wave Refraction Analysis}

This chapter describes procedures and results of the wave data preparation and nearshore wave refraction task of the study. This task consisted of three steps and resulted in the preparation of wave information that was subsequently employed in the numerical shoreline evolution simulations presented in Chapter 3. The first step involved the transformation of hindcast estimates of the offshore wave climate to the Grand Isle project area. In the second step, the time history of wave information at the Grand Isle project area was statistically analyzed and 22 categories of potential wave approach and wave period were identified. The results of the statistical analysis were also used to select a 4-year-long representative time history of wave conditions from the 20-year-long hindcast database. The third step involved the use of a numerical wave refraction model to obtain representative nearshore wave conditions in shallow water at fixed points alongshore.

\section{Wave Hindcast}

No long-term wave measurements are available for the vicinity of the Grand Isle project. Therefore, the required wave information was generated by means of the Wave Information Study (WIS) hindcast technique. The WIS provides a 20-year hindcast for the U.S. Gulf of Mexico coast for the years 1956 through 1975. The Gulf of Mexico hindcast wave information (Hubertz and Brooks, 1989) includes a 20-year time history of wave height, wave direction, and wave period at 3-hr intervals for both sea and swell at 50 stations along the Gulf of Mexico coasts of Florida, Alabama, Mississippi, Louisiana, and Texas. Hindcast Station 21 located offshore of Grand Isle at $28.5 \mathrm{deg}$ north latitude and $90.0 \mathrm{deg}$ west longitude was selected for use in this study.

Phase III transformation. Wave information at WIS Station 21 is representative of wave conditions in $300 \mathrm{ft}$ of water at this geographic location, however, since the location is gulfward of the Mississippi River delta which blocks wave energy approaching from the east, these wave conditions 
are not representative of the waves that impact the Grand Isle project area. Consequently, to obtain estimates of wave conditions representative of those that impact the Grand Isle shoreline, a transformation which included the sheltering effects of the Mississippi River delta, had to be performed on the Station 21 time series. The WIS Phase III transformation technique (Jensen 1983) was used for this transformation. The technique involves a spectral wave transformation procedure that assumes straight and parallel bottom contours between the input station and the user-specified nearshore station. This technique also allows the user to specify sheltering of wave energy from the shoreline in 10-deg increments. The application of this procedure to WIS Station 21 for the Grand Isle project included the following specifications: a) the local shoreline orientation was $52 \mathrm{deg}$ (measured clockwise from north), b) the nearshore water depth to which the transformation was to be made was specified at $42 \mathrm{ft}$ corresponding to the average depth along the offshore boundary of the nearshore bathymetry grid, and c) wave energy sheltering was specified between the shoreline and $70 \mathrm{deg}$ on the eastern side (between 52 and 122 deg azimuth), to account for the sheltering effect of the Mississippi River delta on the local wave climate at Grand Isle. The effect of this transformation on the angular distribution of the incident wave climate is shown in Table 1. Reviewing the data shown in Table 1 , it is seen that 47.2 percent of the waves at WIS Station 21 come from angle bands east of the near shore-normal angle band centered about the compass direction of southeast, whereas, only 15.9 percent come from the western angle bands. This distribution of the incident waves indicates that without sheltering, the net longshore sand transport would be directed from east to west which is incorrect for the Grand Isle project area (U.S. Army Corps of Engineers,

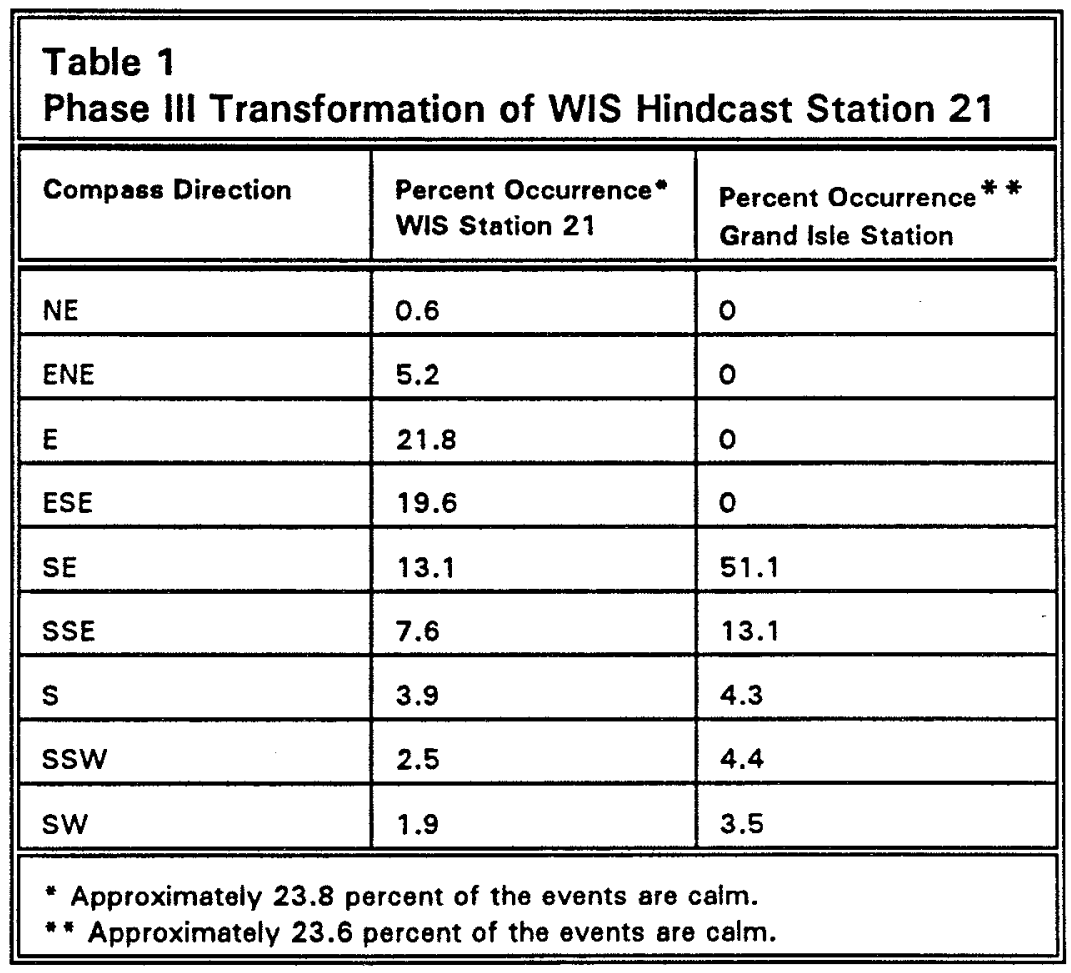


1979), but is the accepted net transport direction along the coast in Cameron Parish in western Louisiana (Hanson et al.1989). After the Phase III transformation with sheltering however, the angular distribution of the incident waves indicates that the net longshore sand transport is directed from west to east with approximately 25.3 percent of the waves arriving from west of shore-normal and effectively no waves arriving from east of shore-normal.

Characteristics of the wave hindcast data set. The next step in the wave data preparation involved computing statistics of the time history of wave information at the Grand Isle Phase III hindcast Station. This analysis involved segregating the time series into 6 wave period bands and 9 angle bands centered about the primary compass directions (e.g. NE, ENE, E, etc.). Then computing for each angle band; the number of events, the average wave angle, the average wave height, and the period bands present in the angle band. Likewise, for each period band; the number of events, the average wave period, the average wave height, and the angle bands present, were computed. The results of these calculations are shown in Tables 2 and 3. Note from Tables 2 and 3, that the incident wave climate at Grand Isle can be characterized by considering a total of 22 angle band / period band combinations. Detailed nearshore wave refraction simulations were performed for each of these 22 categories of incident wave conditions in order to compile a nearshore wave transformation database. Also in Table 2, note that the largest waves approach Grand Isle from the south-southeast angle band and that the majority of the waves approach the island from the near shore-normal southeast angle band. The weighted average incident wave condition has a height of $1.5 \mathrm{ft}$, an angle of $6.5 \mathrm{deg}$ west of shore-normal, and a period of 5.6 sec.

Selection of representative wave conditions. The shoreline change model (described in Chapter 3 ) requires input wave conditions which are used to compute longshore sand transport rates and shoreline change. Because the calibration (1985 - 1990) and verification (1990 - 1992) time periods are not encompassed by the hindcast, and because the model will be used to predict future shoreline changes, a time history of representative wave conditions is required. Since the purpose of the shoreline change model is to estimate shoreline evolution over several years, the representative time series should reflect as near as possible the characteristics of the entire 20 -year database. The procedure employed to identify those years most representative of the 20year database is outlined below.

First, the 20-year-long hindcast time history was separated into 201 -yearlong time series. Statistics similar to those shown in Table 2, and potential longshore sand transport rates were computed for each of the 1-year-long time series. Using the statistics of average significant wave height and frequency of occurrence in each of the 6 angle bands along with potential longshore sand transport rates for each year, the average and standard deviation of 16 characteristics of the incident wave climate was computed for the 20-year database. The 16 characteristics are comprised of the average significant 


\begin{tabular}{|c|c|c|c|c|}
\hline \multicolumn{5}{|c|}{$\begin{array}{l}\text { Table } 2 \\
\text { Grand Isle Phase III Hindcast Station } \\
\text { Classification of Wave Events by Angle Band }\end{array}$} \\
\hline $\begin{array}{l}\text { Center Angle Relative } \\
\text { to Compass Direction }\end{array}$ & Number of Events & $\begin{array}{l}\text { Average } \\
\text { Wave Angle } \\
\text { (w.r.t. } \\
\text { shore- } \\
\text { normal) }\end{array}$ & $\begin{array}{l}\text { Average Wave } \\
\text { Height (ft) }\end{array}$ & Period Bands \\
\hline NE & 0 & - & - & - \\
\hline ENE & 0 & . & - & - \\
\hline$E$ & 0 & - & - & - \\
\hline ESE & 10 & 18.3 & 0.33 & 2 \\
\hline SE & 59,730 & 7.3 & 1.3 & $1,2,3,4,5,6$ \\
\hline SSE & 15,245 & -12.7 & 2.1 & $1,2,3,4,5$ \\
\hline s & 5,047 & -37.1 & 1.8 & $1,2,3,4$ \\
\hline ssw & 5,167 & -60.8 & 1.3 & $1,2,3,4$ \\
\hline sw & 4,106 & .79 .5 & 0.79 & 1,2 \\
\hline
\end{tabular}

\begin{tabular}{|c|c|c|c|c|}
\hline \multicolumn{5}{|c|}{$\begin{array}{l}\text { Table } 3 \\
\text { Grand Isle Phase III Hindcast Station } \\
\text { Classification of Wave Events by Period Band }\end{array}$} \\
\hline Period Range (sec) & Number of Events & $\begin{array}{l}\text { Average } \\
\text { Period (sec) }\end{array}$ & $\begin{array}{l}\text { Average Wave } \\
\text { Height (ft) }\end{array}$ & Angle Bands \\
\hline $0.0<T<5.0$ & 20,162 & 3.5 & 1.2 & $5,6,7,8,9$ \\
\hline $5.0 \leq T<7.0$ & 46,269 & 5.6 & 1.5 & $4,5,6,7,8,9$ \\
\hline $7.0 \leq T<9.0$ & 21,252 & 7.3 & 1.7 & $5,6,7,8$ \\
\hline $9.0 \leq T<11.0$ & 1,544 & 9.2 & 1.8 & $5,6,7,8$ \\
\hline $11.0 \leq T<13.0$ & 75 & 11.1 & 0.89 & 5,6 \\
\hline $13.0 \leq T<15.0$ & 3 & 14.0 & 0.56 & 5 \\
\hline
\end{tabular}

wave height and percent occurrence in 6 angle bands, and left-directed, rightdirected, net, and gross potential longshore sand transport rates. Next, the values of the 16 characteristics for each of the 1-year-long time series were compared to the 20-year average and standard deviation. If the value of the characteristic was within plus or minus one standard deviation of the 20 -year 
average, the year was considered representative of the 20-year database for that characteristic. Through this procedure the years 1958, 1965, 1971 and 1972 were selected as representative of the hindcast database, with between 12 and 13 characteristics considered representative in each of the years. Table 4 summarizes this analysis the shaded cells denote categories that are outside the representative tolerance of plus or minus one standard deviation of the 20-year average.

\begin{tabular}{|c|c|c|c|c|c|c|c|c|c|c|c|c|c|c|}
\hline \multirow{3}{*}{$\begin{array}{c}\begin{array}{l}\text { Table } 4 \\
\text { Selection }\end{array} \\
\text { Angle Band } \\
\text { Year }\end{array}$} & ne & Cos & at & 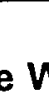 & ive & on & or & fo & Gro & Is & L & & & \\
\hline & \multicolumn{2}{|c|}{5} & \multicolumn{2}{|c|}{6} & \multicolumn{2}{|c|}{7} & \multicolumn{2}{|c|}{8} & \multicolumn{2}{|c|}{$\mathbf{9}$} & \multicolumn{4}{|c|}{ Potential Transport Rate } \\
\hline & $\#$ & H & $\#$ & H & $\#$ & H & $\#$ & H & $*$ & $\mathbf{H}$ & Left & Right & Net & Gross \\
\hline 1956 & 2591 & 1.3 & 1013 & 2.1 & 315 & 1.7 & 351 & 1.3 & 212 & 0.8 & 243 & 84 & 189 & 297 \\
\hline 1957 & 2669 & 1.4 & 939 & 29 & 270 & 1.9 & 421 & 1.3 & s/ & 0.8 & 285 & 59 & 226 & 344 \\
\hline 1958 & 3160 & 1.4 & 638 & 2.1 & 281 & 1.8 & 234 & 1.4 & 152 & 0.7 & 177 & 89 & 88 & 266 \\
\hline 1959 & 3068 & 1.4 & 788 & 2.0 & 212 & 13 & 243 & 1.2 & 211 & 0.9 & 150 & 65 & 85 & 215 \\
\hline 1960 & 3149 & 1.3 & 560 & 19 & 212 & 16 & 258 & 1 & 226 & 0.8 & 129 & 65 & 64 & 194 \\
\hline 1961 & 3015 & 1.3 & 776 & 34 & 660 & 1.8 & 139 & 1.2 & 126 & 0.6 & 218 & 76 & 142 & 294 \\
\hline 1962 & 2896 & 1.2 & 835 & 2.0 & 199 & 15 & 220 & 1 & 248 & 0.7 & 149 & 59 & 90 & 208 \\
\hline 1963 & 3125 & 1.2 & 590 & 2.0 & 297 & 1.8 & 222 & 1.2 & 185 & 0.7 & 145 & 72 & 73 & 217 \\
\hline 1964 & 3216 & 1.3 & 735 & 23 & 269 & 20 & 212 & 1.3 & 151 & 0.9 & 243 & 77 & 166 & 320 \\
\hline 1965 & 3310 & 1.3 & 752 & 2.1 & 272 & 1.9 & 231 & 1.2 & 208 & 0.8 & 195 & 78 & 117 & 273 \\
\hline 1966 & 2825 & 1.3 & 709 & 10 & 263 & 1.6 & 234 & 1.3 & 232 & 0.8 & $\mathrm{lll}$ & 68 & 63 & 199 \\
\hline 1967 & 2071 & 1.2 & 932 & 2.1 & 355 & 1.6 & 36 & 1.4 & 190 & 0.8 & 251 & so & 201 & 301 \\
\hline 1968 & 2560 & 1.2 & 907 & 2.0 & 255 & 1.8 & 233 & 1.2 & 216 & 0.8 & 183 & 48 & 135 & 231 \\
\hline 1969 & 2687 & 1.3 & 448 & 2.0 & 300 & 1.8 & 381 & 1.3 & 232 & 10 & 158 & 81 & 77 & 239 \\
\hline 1970 & 2944 & 1.3 & 781 & 2.1 & 245 & 1.8 & 294 & 1.2 & 250 & 10 & 163 & 64 & 99 & 227 \\
\hline 1971 & 2968 & 1.3 & 935 & 2.2 & 167 & 1.8 & 250 & 1.2 & 193 & 0.8 & 199 & 68 & 131 & 267 \\
\hline 1972 & 2887 & 1.4 & 730 & 2.1 & 282 & 1.7 & 324 & 1.4 & 248 & 0.8 & 182 & 88 & 94 & 270 \\
\hline 1973 & 2993 & 16 & 667 & 24 & 343 & 1.8 & 247 & 1.3 & 261 & 0.8 & 259 & 80 & 179 & 339 \\
\hline 1974 & 3179 & 15 & 805 & 23 & 227 & 21 & 154 & 1.4 & 149 & 0.8 & $2 s 2$ & 98 & 154 & 350 \\
\hline 1975 & 3497 & 1.4 & 705 & 2.2 & 123 & 1.9 & 163 & 1.4 & 16s & 0.8 & 156 & 114 & 42 & 270 \\
\hline \multicolumn{15}{|c|}{ 20-year Average \& Standard Deviation } \\
\hline AVERAGE & 2987 & 1.3 & 762 & 2.1 & 252 & 1.8 & 258 & 1.3 & 205 & 0.8 & 193 & 73 & 121 & 266 \\
\hline S.D. & 257 & 0.1 & 139 & 0.1 & 59 & 0.1 & 73 & 0.1 & 39 & 0.1 & 47 & 16 & 50 & 48 \\
\hline \multicolumn{15}{|c|}{ "Representative" Tolerance } \\
\hline$A V G+S . D$ & 3244 & 1.4 & 901 & 2.2 & 311 & 1.9 & 331 & 1.4 & 244 & 0.9 & 240 & 89 & 171 & 314 \\
\hline$A V G-S . D$ & 2730 & 1.2 & 623 & 2.0 & 193 & 1.7 & 185 & 1.2 & 166 & 0.7 & 146 & 57 & 71 & 218 \\
\hline
\end{tabular}




\section{Nearshore Wave Transformation Simulation}

Wave transformation model. An estimation of wave transformation from the nominal $42 \mathrm{ft}$ depth to the nominal $14 \mathrm{ft}$ depth along the Grand Isle shoreline was made by application of the Regional Coastal Processes Wave Propagation Model, RCPWAVE (Ebersole et al. 1986). RCPWAVE was specifically designed for use in projects with large spatial extent, such as in the present case. This model is superior to classical wave ray refraction procedures in that energy propagation along wave crests due to irregular bathymetry is accounted for in addition to energy propagation in the direction of ray travel. The model is also more efficient than traditional wave ray models since the governing equations are solved directly on a user-specified depth (bathymetry) grid in the horizontal plane (by an iterative finite difference solution scheme) rather than by ray shooting and interpolation to the grid.

Basic assumptions used in RCPWAVE are:

a. Mild bottom slopes.

b. Linear, monochromatic, and irrotational waves.

c. Negligible wave reflection.

d. Negligible energy losses due to bottom friction or wave breaking outside of the surf zone.

These assumptions are common to most numerical models used for engineering applications. Results from the model are expected to be sufficiently accurate to be used in the estimation of longshore sand transport rates and shoreline change.

Model grid and boundary conditions. The RCPWAVE model bathymetry grid used in this project is rectangular, with its alongshore axis taking a 52deg azimuth orientation. The grid contained 520 cells across-shore and 396 cells alongshore for a total mesh of 205,920 cells describing the nearshore bathymetry offshore of the Grand Isle project reach. Figure 2 provides a contour plot of the bathymetry grid used in the nearshore wave transformation simulations. The cell spacing in the alongshore direction is $100 \mathrm{ft}$ and is $50 \mathrm{ft}$ in the cross-shore direction. This cell spacing was selected to maximize the resolution of any irregularities in the longshore breaking wave field induced by unusual bottom features such as the nearshore borrow pit indicated in Figure 2. The bathymetry grid extends beyond Grand Isle on either side to about the middle of Caminada Pass and Barataria Pass on the west and east, respectively. Across-shore, the grid extends from the shoreline to about the $42-\mathrm{ft}$ contour. The shoreline change model will use wave transformation results from alongshore coordinates 34 to 353 at the 14-ft contour line for the Grand Isle reach. Nearshore bathymetry data from LMN bathymetric surveys 


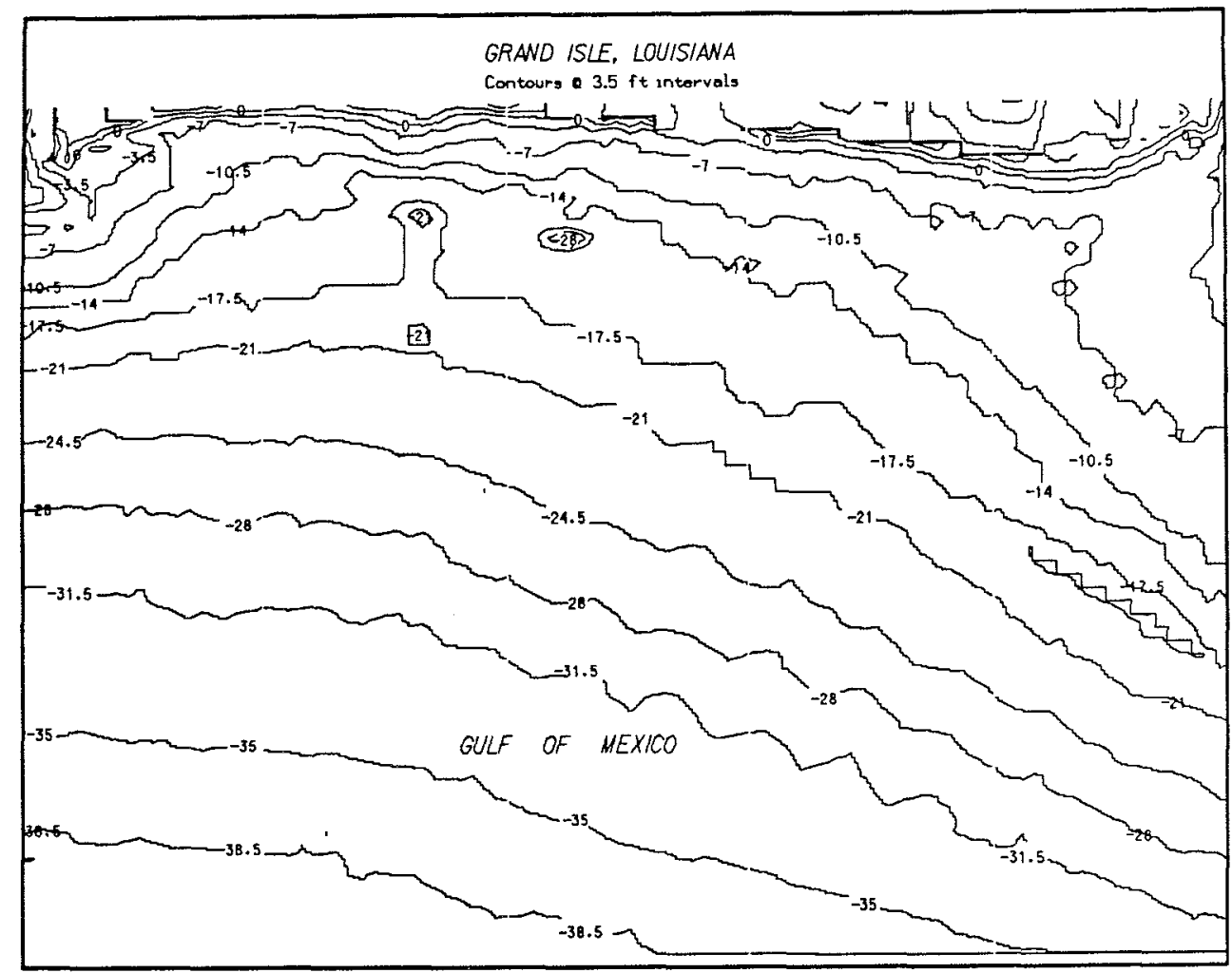

Figure 2. Contour plot of Grand Isle nearshore bathymetry grid

of 1990 and 1992 were used together with deeper water bathymetery data obtained from the hydrographic database compiled by the National Oceanic and Atmospheric Administration (NOAA), National Geophysical Data Center (NGDC), to generate the nearshore bathymetry grid.

Nearshore Wave Transformation Simulations. Wave transformation simulations were performed for each of 22 angle band / period band combinations identified previously in Tables 2 and 3. Simulations of wave conditions occurring in angle band 9 resulted in numerical instability due to their extremely oblique offshore incident wave angle (waves tended to refract offshore), therefore waves in this angle band were shifted into angle band 8 . This incident angle shift effected only about 4.6 percent of the wave events in the 20-year database. For illustrative purposes the results of the nearshore wave transformation simulations for the three most frequently occurring angle band / period band combinations are shown in Figures 3 and 4. In Figure 3, computed wave height transformation coefficients along the nominal $14 \mathrm{ft}$ contour line for angle band 5 period bands 2, 3, and 1 are plotted. Likewise, Figure 4 shows the nearshore incident wave angle along the 14- $\mathrm{ft}$ contour line. These three angle band / period band combinations represent approximately 65 percent of the wave events in the 20-year database. In the figures, alongshore coordinate 1 corresponds to Caminada Pass at the western end of the island and alongshore coordinate 396 corresponds to Barataria Pass at the eastern end of the island. In Figure 3 it is seen that nearshore wave heights are basically 


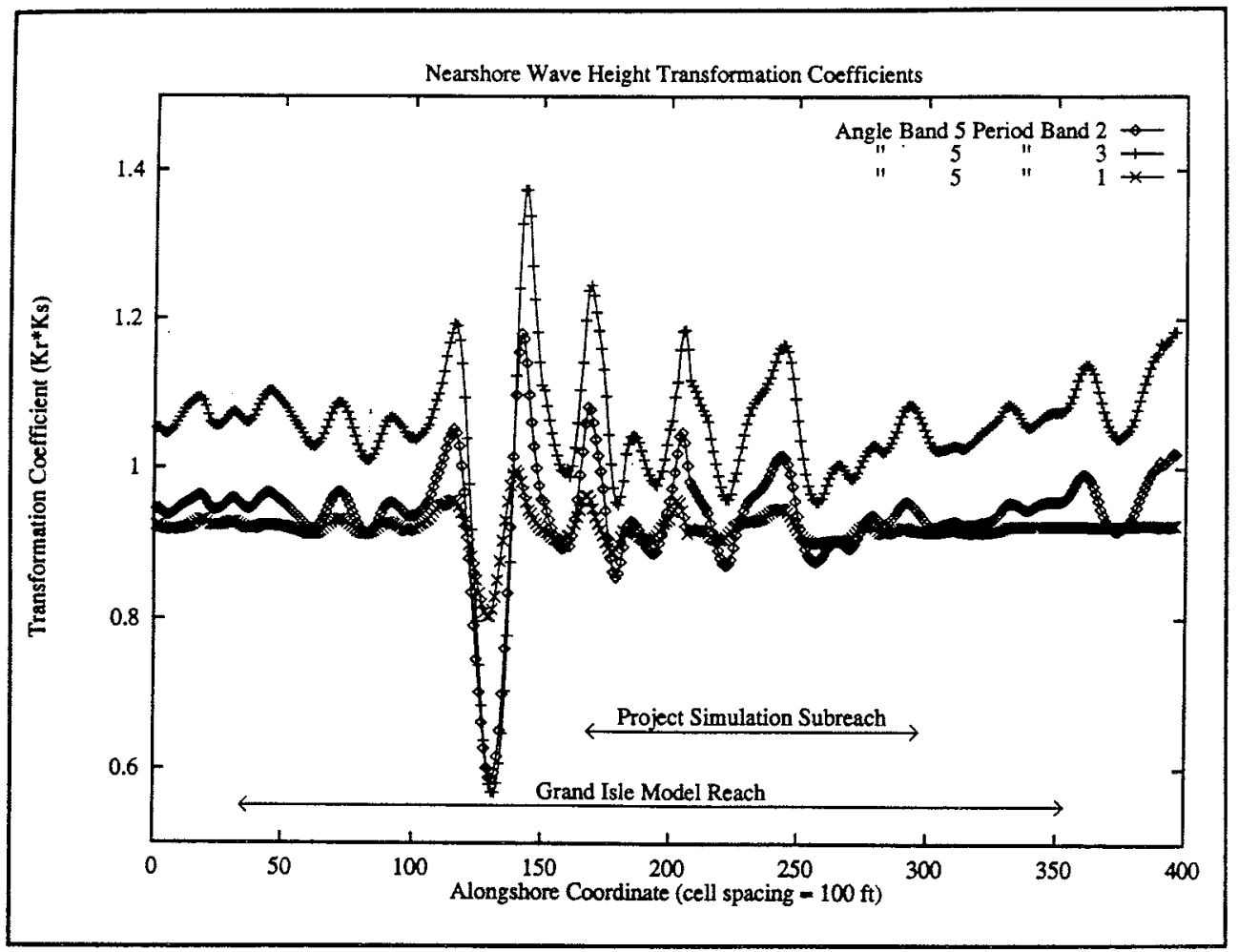

Figure 3. Nearshore wave height transformation coefficients

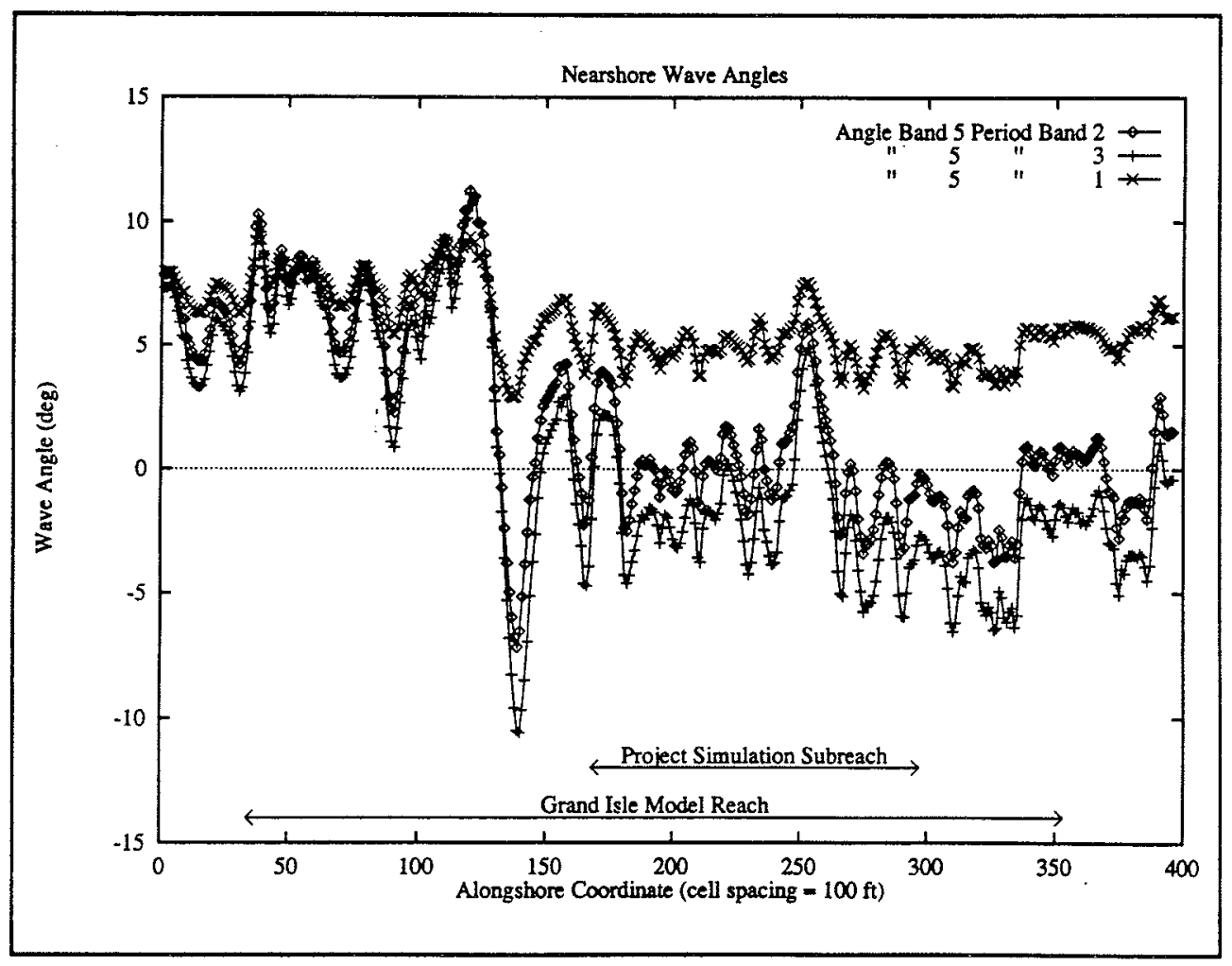

Figure 4. Nearshore wave angles 
uniform between alongshore coordinates 1 and 100 and tend to increase between coordinates 250 and 396. Between cells 100 and 250 rhythmic variations in the nearshore wave height are estimated, the most significant of which occurs between alongshore coordinates 100 and 160 where the height transformation coefficient varies from a low of 0.6 to a high of about 1.4. From alongshore coordinates 160 to 250 the variations in the nearshore wave height are reduced with a maximum variation of approximately 0.2 . In Figure 4 it is seen that nearshore wave angles, tend to become more negative moving from west to east indicating that the magnitude of east bound longshore sand transport rates will increase from west to east along the island. In fact, for longer wave periods (period bands 2 and 3 ) in this nearly shore-normal angle band the nearshore wave angles are positive at the western end of the island and are generally negative near the center of the island indicating that the net longshore sand transport will be directed to the west near the western end of the island and then reverse in direction and become east bound somewhere around the western third of the island. Of primary interest is the large alongshore variations in the transformed wave height and nearshore wave angle between coordinates 100 and 160 . This region corresponds to the location of the borrow pit (centered about grid cell 130) that was excavated for the 1984 Grand Isle beach nourishment. Figures 5 and 6 show the nearshore wave height transformation coefficients and wave angles for this region. Note by comparing Figures 5 and 6 that at grid cell 130 the wave height transformation coefficient is at its minimum and the corresponding wave angle is nearly shore-normal $(0 \mathrm{deg})$. To the west of cell 130 (lower coordinate values) the wave height transformation coefficient increases to approximately 1.2 near alongshore coordinate 120 and the wave angles become positive. To the east of cell 130 the wave height transformation coefficient increases to approximately 1.4 near alongshore coordinate 140 and the wave angles become negative. Direct interpretation of these results with regard to longshore sand transport processes using the energy flux method (Shore Protection Manual (SPM), 1984) would lead one to conclude that sand would be transported away from the lee of the borrow pit and that the shoreline would erode directly behind the borrow pit and accrete further away as wave heights decrease (around cells 100 and 160). As will be seen in Chapter 3, this interpreted result is opposite of the observed result. The reason for this misinterpretation is a pitfall of the energy flux method which does not directly take into account nearshore currents but rather assumes that the longshore current will be directed by the incident wave angle. However, in this case the large gradients in alongshore wave height are apparently significant enough to generate nearshore currents (directed from areas of large wave height to areas of low wave height) that overwhelm longshore currents generated by waves breaking at oblique angles to the shoreline. In reality however, the nearshore currents caused by the alongshore gradients in wave height modify subsequent wave transformation in the lee of the borrow pit such that the breaking wave angles are reversed from those shown in Figure 6 and complement the circulation caused by the alongshore gradients in wave height. This process became a major factor in the numerical simulation of shoreline change at Grand Isle and is further discussed in Chapter 3. 


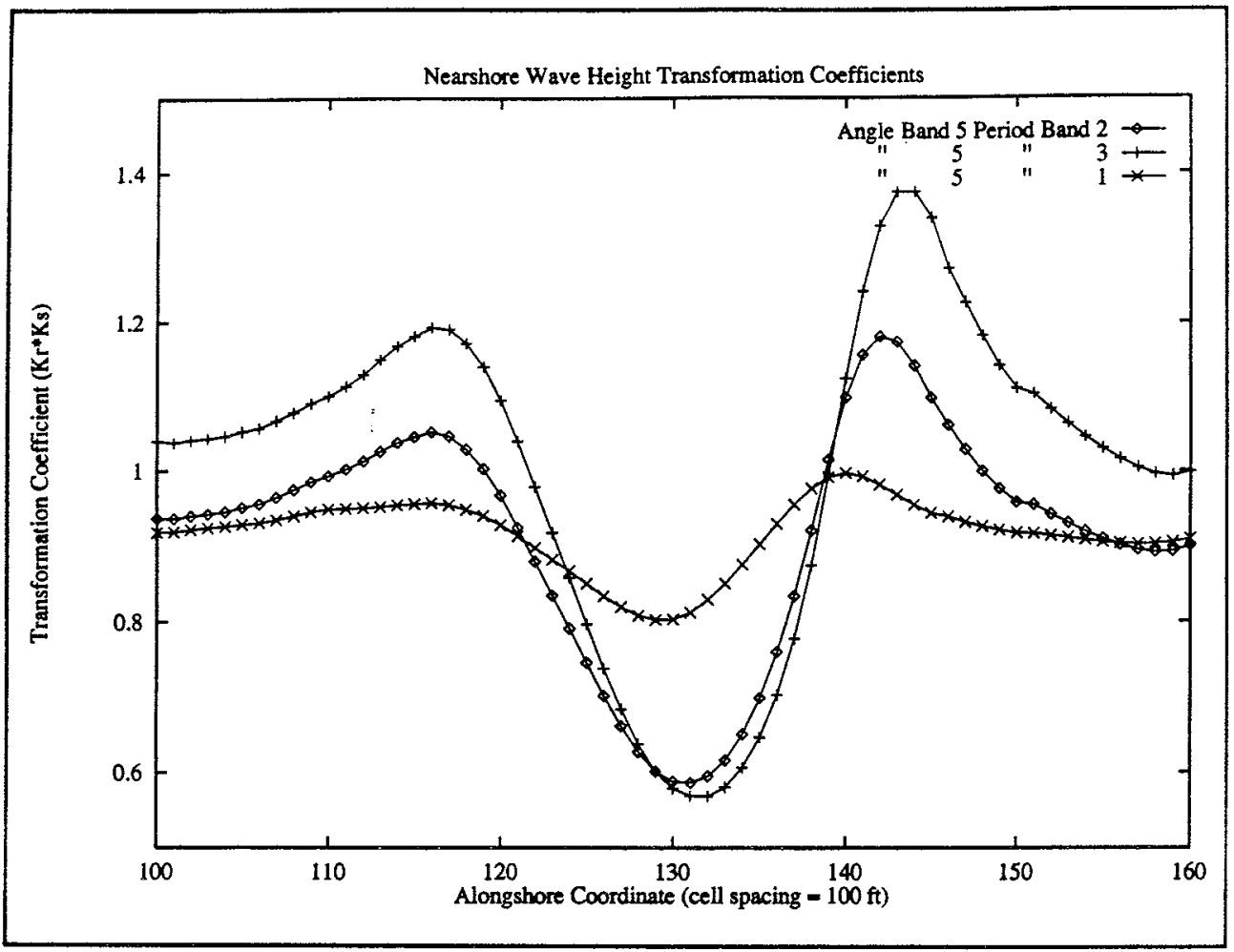

Figure 5. Nearshore wave height transformation coefficients near borrow pit

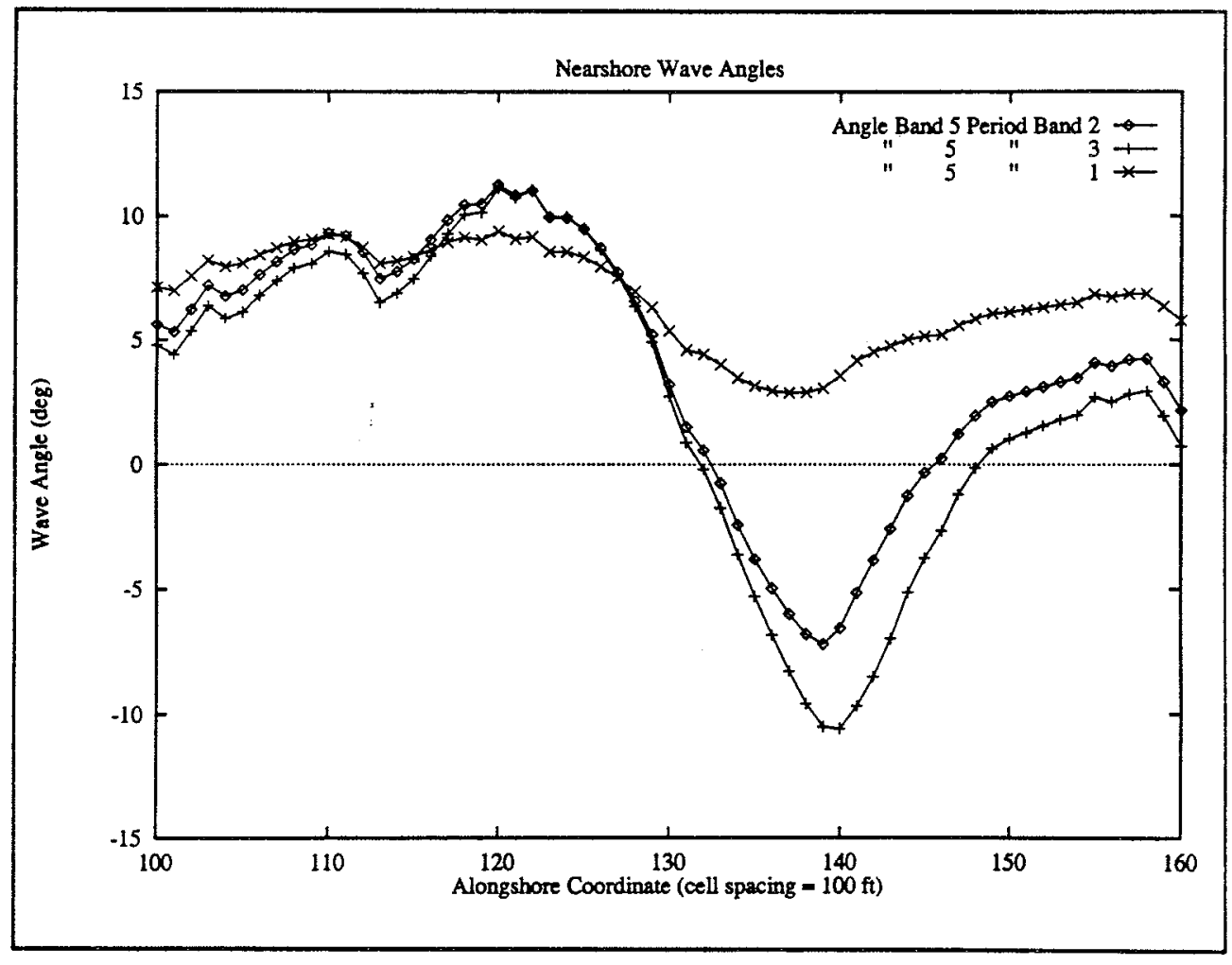

Figure 6. Nearshore wave angles near borrow pit 


\section{Long-Term Shoreline Change}

\section{Introduction}

A primary task of this study was to numerically simulate shoreline change along the gulfward shoreline of Grand Isle. The shoreline change model GENESIS (Hanson 1987, Hanson and Kraus 1989) was utilized for assessment of the longshore sand transport processes and long-term shoreline change along the project reach.

On an open coast such as the present project area, shoreline change occurring over several years or decades is believed to be controlled by the transport of sand alongshore. The dominant process producing this alongshore movement of sand is typically the energy dissipation associated with waves breaking at oblique angles to the shoreline. Other important processes influencing shoreline change along Grand Isle are tidal currents and inlet processes, which at the ends of Grand Isle can be significant and may in fact control shoreline evolution in these areas as will be seen. Consequently, the boundaries of the model reach were selected at relatively stable shoreline locations some distance away from the ends of the island. Prior to the development of numerical models of shoreline evolution, sediment budget analysis techniques were applied in studies of this type. The basic sediment budget analysis still commonly used in coastal engineering and geology is an arithmetic balance of beach volume changes with inputs and outflows of sediment at the landward, seaward, and lateral boundaries of the region considered. The shoreline change model GENESIS is a sophisticated implementation of the sediment budget analysis method, in which the change in beach volume is calculated at finely spaced intervals (specifically, at $25-\mathrm{ft}$ intervals in this study) along the project reach as a function of time-varying wave conditions.

Shoreline change along Grand Isle can be characterized by two dominant processes, one being a long-term evolution which is manifested as a clockwise rotation of the island about a relatively stable midpoint with shoreline retreat to the west and shoreline accretion to the east. The other dominant process 
causing major shoreline change at Grand Isle is severe erosion events caused by hurricanes and tropical storms. Grand Isle in general is low, with elevations ranging between 3 and $5 \mathrm{ft}$ mean sea level (msl). Consequently, even relatively mild storm events can cause major flooding and major events can completely inundate the island resulting in sheet flow of storm water over the island. During major storm events, sand is carried from the beach and deposited in upland areas as well as offshore. Lesser storm events generally erode material from the beach and deposit it offshore.

The purpose of this task was to estimate the influence of a series of segmented detached breakwaters on shoreline evolution within and adjacent to the project reach. Shoreline response to the system of breakwaters was expected to be controlled primarily by long-term processes as influenced by normal wave activity, excluding extreme or storm conditions. Hence, application of a numerical shoreline change model was expected to be an efficient means for quantifying the long-term effects of the proposed detached breakwater project on shoreline evolution.

This chapter is structured in three sections. The first section is an introduction to the shoreline change model, which includes a brief summary of the basic model assumptions and a discussion of the modeled structures. Because the target of this study is the prediction of the evolution of the shoreline adjacent to and in the lee of various proposed detached breakwater configurations, a basic understanding of the model's algorithmic structure is necessary. The model's structure includes the concept of wave energy windows, procedures for computing wave diffraction coefficients, wave transmission at detached breakwaters, and procedures for handling multiple sources of wave diffraction. The second section provides a discussion of calibration and verification of GENESIS for the project reach. The final section presents results of several model simulations of proposed breakwater project configurations, together with relevant discussion.

\section{Shoreline Change Model GENESIS}

\section{Background}

The numerical model GENESIS is a one-contour line beach evolution model of the type first introduced by Pelnard-Considere (1956). The acronym GENESIS stands for GENEralized model for SImulating Shoreline change. GENESIS was developed by Hanson (1987) in a cooperative research project with CERC and is a generalized system of numerical models and computer subroutines which allows simulation of long-term shoreline change under a wide variety of user-specified conditions. Report 1 (Hanson and Kraus 1989) of the GENESIS series is a technical reference and planner's guide for use of the model. Report 2 (Gravens, Kraus, and Hanson 1991) provides a workbook and further guidance to users related to the assembly and processing of input data sets, and interpretation of model results. 
GENESIS calculates the longshore sand transport rate and resulting plan shape of the modeled coast at short time intervals over of the course of a simulation period. The effects of coastal structures such as seawalls, groins, detached breakwaters, and beach fills on the longshore sand transport rate are incorporated in the model by the use of appropriate boundary conditions and constraints. Wave diffraction at detached breakwaters and long groins is represented around and behind the structures in the calculation of shoreline change.

GENESIS accepts two types of wave inputs depending on the available data and degree of computation effort required. A single offshore wave condition can be input, and the wave model within GENESIS will calculate the breaking wave conditions along the modeled reach. The wave model in GENESIS is based on linear wave theory and the assumption of a uniformly sloping bottom with parallel contours. Wave refraction and shoaling are iteratively calculated using Snell's Law, and the principle of wave energy conservation is used to satisfy a breaking criterion. Diffraction is included in the calculation of breaking waves for grid cells located in the lee of diffractive structures. Alternatively, a more sophisticated wave transformation model (such as RCPWAVE) which describes wave propagation over a digitized offshore bathymetry can be used to perform the required wave transformations from offshore to (pre-breaking) shallow water. In this case, GENESIS retrieves the nearshore wave characteristics (output from RCPWAVE in the form of a height transformation coefficient $\left(\mathrm{K}_{\mathrm{r}} \mathrm{K}_{\mathrm{r}}\right)$ and nearshore incident wave angle $\theta_{\text {ref }}$ ) from a user-defined database and performs local refraction, diffraction, and shoaling calculations to obtain a breaking wave height and angle with respect to the shoreline. In either case, once a breaking wave field along the modeled reach is available, longshore sand transport rates can be calculated and the shoreline position updated.

\section{Shoreline model theory}

The goal of shoreline change modeling is to describe long-term evolution of shoreline position, in which the beach profile is assumed to maintain an arbitrary equilibrium shape. This implies that bottom contours are parallel and that the entire profile is translated an equal distance either seaward or landward for an accreting or eroding shoreline, respectively. Under this assumption, it is necessary to consider the movement of only one contour line, conveniently taken to be the shoreline. In the present study, mean high water (mhw) shoreline positions were digitized from aerial photographs of the gulfward shoreline of Grand Isle for the years 1985, 1990, and 1992. The January 26, 1985 and June 25, 1990 shorelines were used in the GENESIS calibration simulations, whereas the June 25, 1990 and August 30, 1992 shorelines were used in the GENESIS verification simulations.

In the model, longshore sand transport occurs uniformly over the active beach profile, defined as the vertical distance between the average berm height $(5 \mathrm{ft}$ mhw for Grand Isle) and the depth of closure ( $-15 \mathrm{ft}$ mhw for Grand 
Isle). Longshore sand transport is assumed negligible at depths greater than the depth of closure. Therefore, a change in shoreline position $\Delta y$ can be related to the change in cross-sectional area $\Delta \mathrm{A}$ according to Equation 1:

$$
\Delta \mathrm{A}=\Delta \mathrm{yD}
$$

where

$$
\begin{aligned}
\Delta \mathrm{A}= & \text { change in cross-sectional beach area }\left(\mathrm{ft}^{2}\right) \\
\Delta \mathrm{y}= & \text { change in shoreline position }(\mathrm{ft}) \\
\mathrm{D}= & \text { active profile height }(\mathrm{ft}) \text { (average berm height plus depth of } \\
& \text { closure) }
\end{aligned}
$$

By considering a control volume of sand and formulating a mass balance during an infinitesimal interval of time, the following differential equation is obtained:

$$
\frac{\partial Q}{\partial x}+\frac{\partial A}{\partial t}=0
$$

where

$$
\begin{aligned}
& \mathrm{Q}=\text { longshore sand transport rate }\left(\mathrm{ft}^{3} / \mathrm{sec}\right) \\
& \mathrm{A}=\text { cross-sectional area of beach }\left(\mathrm{ft}^{2}\right) \\
& \mathrm{X}=\text { alongshore space coordinate }(\mathrm{ft}) \\
& \mathrm{t}=\text { time }(\mathrm{sec})
\end{aligned}
$$

Equation 2 requires that a variation in the longshore sand transport rate be balanced by changes in the shoreline position. Therefore, at a given time step, $\Delta \mathrm{y}$ is equal to $\left(\mathrm{Q}_{\mathrm{in}}-\mathrm{Q}_{\text {out }}\right) /(\mathrm{D} \Delta \mathrm{x})$.

In order to solve Equation 2, it is necessary to specify an expression for the longshore sand transport rate. The predictive formula for $Q$ used in GENESIS is,

$$
\mathrm{Q}=\frac{\mathrm{H}_{\mathrm{b}}^{2} \mathrm{Cg}_{\mathrm{b}}}{16(\mathrm{~S}-1)(1-\mathrm{a})}\left[\mathrm{K}_{1} \sin \left(2 \alpha_{\mathrm{bs}}\right)-\mathrm{K}_{2} 2 \frac{\mathrm{dH}_{\mathrm{b}}}{\mathrm{dx}} \cot (\beta) \cos \left(\alpha_{\mathrm{ba}}\right)\right]
$$

where

$$
\begin{aligned}
\mathrm{H}_{\mathrm{b}} & =\text { breaking wave height }(\mathrm{ft}) \\
\mathrm{Cg}_{\mathrm{b}} & =\text { wave group velocity at breaking }(\mathrm{ft} / \mathrm{sec}) \\
\mathrm{S} & =\text { ratio of sediment (quartz) density to water density }(\mathrm{S}=2.65) \\
\mathrm{a} & =\text { sediment porosity }(\mathrm{a}=0.4) \\
\alpha_{\mathrm{bs}} & =\text { breaking wave angle with respect to the shoreline } \\
\cot (\beta) & =\text { inverse beach slope }
\end{aligned}
$$

The quantities $K_{1}$ and $K_{2}$ are empirical coefficients and are treated as calibration parameters. 
The first term in Equation 3 corresponds to the "CERC formula" described in the SPM (1984, Chapter 4) and provides an estimate of the sand transport produced by obliquely incident breaking waves. The second term estimates sand transport produced by a longshore current resulting from a gradient in the breaking wave height alongshore. The first term is typically dominant on an open coast away from diffracting structures, however, the second term provides a significant correction if diffraction enters into the problem (Ozasa and Brampton 1980, Kraus 1983, Kraus and Harikai 1983). Also, in the calibration of GENESIS for Grand Isle, it was determined that a substantial longshore gradient in wave heights due to wave transformation over a nearshore borrow pit resulted in a nearshore circulation and associated shoreline evolution that could only be described by the second term in Equation 3, as discussed in a subsequent section.

The SPM recommends a value of $K_{1}=0.77$ using the root-mean-square wave height in Equation 3, and the coefficient $\mathrm{K}_{2}$ has been empirically found to lie in the range $0.5 \mathrm{~K}_{1} \leq \mathrm{K}_{2} \leq 1.0 \mathrm{~K}_{1}$.

Lateral boundary conditions are required in the solution prescribed in Equation 2. Typical boundary conditions are limited sand transport, such as at a long groin, and uniform transport, such as at a stable beach. Other boundary conditions may be formulated as required.

\section{Representation of structures}

Effects of groins and detached breakwaters on long-term shoreline evolution were modeled within the Grand Isle project reach. The algorithms that handle the simulation of these structures within GENESIS and an overview of the influence of the these structures on longshore sand transport processes is discussed in this section.

Groins. The positions and lengths of the groins were obtained from the June 1990 aerial photographs. The two groins located at the ends of the town of Grand Isle breakwater and groin system were simulated in the model. A total of 14 groins were constructed by the Louisiana Department of Highways in 1951-1952. These groins were not simulated in the model since they do not appear to be significantly influencing shoreline change except when the shoreline is in a highly eroded state, and even then their influence is believed to be minimal. In fact, in the 1985 and 1992 aerial photographs these groins cannot be detected, and are apparently completely buried. In the June 1990 aerial photographs, which show the Grand Isle shoreline in a highly eroded state, groins can be detected east of the breakwater and groin system constructed by the town of Grand Isle. Because these groins influence shoreline change only at times when the shoreline is in a highly eroded state and these conditions were not predicted in the project simulations, their exclusion from the model is appropriate. 
Bypassing at groins. If only longshore sand transport is considered, in principle and in the model, a high crested groin extending well beyond the surf zone will completely block the longshore movement of sand. In practice, most groins are of such length that the surf zone often extends beyond the groin tip (as is the case at Grand Isle). Consequently, sand is transported past the groin. Rip currents and complex circulation patterns within groin compartments also act to remold the shoreline position and to move sand around a groin. During high tides and severe wave conditions, sand may be bypassed over the crest or landward of the groin. Furthermore, if a groin contains voids or is of insufficient elevation, sand moving alongshore can pass through and/or over the groin. Inspection of the groins at the town of Grand Isle breakwater and groin system revealed evidence of sand moving past the groins through both bypassing and transmission. In GENESIS, transport of sand alongshore seaward of the groin tip is called bypassing and sand transported over, through, or landward of the groin is called transmission.

Bypassing and transmission of sand alongshore at groins within the project reach is represented in the model through use of empirical algorithms.

Transmission of sand past a groin in GENESIS is represented by specifying a "permeability" factor which may range from 0 (no sand transmission) to 1 (complete sand transmission, no groin). The predicted quantity of sand which moves across a groin by transmission is calculated as a fraction of the potential longshore sand transport rate (the transport rate calculated as if no groin were present) (Hanson and Kraus 1980, Gravens and Kraus 1989). No data sets are available to directly estimate groin permeability. Consequently, assigning a permeability factor to a particular groin becomes, in effect, part of the calibration and verification process.

Bypassing of groins in GENESIS is determined at each time step based on the depth of longshore sand transport pertaining to the wave conditions which exist at the particular time step. For the purpose of determining if groin bypassing will occur, an expression given by Hallermeier $(1979,1983)$ is used,

$$
\mathrm{D}_{\mathrm{LT}}=2.28 \mathrm{H}-10.9 \frac{\mathrm{H}^{2}}{\mathrm{~L}}
$$

in which $\mathrm{D}_{\mathrm{Lr}}$ is the depth of littoral transport for incident wave conditions, $\mathrm{H}$ is the significant wave height in deep water and $L$ is the deep-water wave length. For calculating the distribution of the longshore sand transport rate and shoreline change, the depth of closure was held constant at $15 \mathrm{ft} \mathrm{mhw}$. The "bypassing factor," is calculated assuming a rectangular distribution of the longshore sand transport rate as follows,

$$
\mathrm{BYP}=\left\{\begin{array}{c}
1-\frac{\mathrm{D}_{\mathrm{g}}}{\mathrm{D}_{\mathrm{LT}}}, \mathrm{D}_{\mathrm{LT}}>\mathrm{D}_{\mathrm{g}} \\
0, \mathrm{D}_{\mathrm{LT}} \leq \mathrm{D}_{\mathrm{g}}
\end{array}\right\}
$$


in which $\mathrm{D}_{\mathrm{g}}$ is the depth at the seaward end of the groin. Note that a rectangular distribution of the transport rate provides a reasonable approximation to available field data sets (Kraus and Dean 1987).

A theoretically complete analysis of sand transport past a groin either by transmission or bypassing would require knowledge of the cross-shore and vertical distributions of the longshore sand transport rate as well as the horizontal circulation and transport patterns. Although knowledge of the latter is beyond the present state of the art, the permeability factor allows the modeler to adjust the model to best represent longshore sand transport processes and subsequent shoreline change near groins. For the former, there is not enough field data to estimate the vertical distribution of the longshore sand transport rate. Theoretical expressions exist to predict the cross-shore distribution of the longshore transport rate; however, all pertain to idealized conditions and none have been verified. In light of these circumstances, the assumptions above produce reasonable results.

Breakwaters. As stated earlier the purpose of this study was to estimate the influence of a series of segmented detached breakwaters on shoreline evolution adjacent to and in the lee of the proposed breakwaters. Breakwaters function by reducing the wave energy that is ultimately expended on the shoreline. This reduction of wave energy is realized by the breakwaters ability to intercept incident waves prior to breaking and producing a nearcircular diffracting wave pattern emanating from each tip of the breakwater. This distortion of the wave field is a significant factor controlling the response of the shoreline in the lee of the breakwater. Sand typically accumulates in the diffraction shadow (that area not directly impacted by incident waves) of the breakwater, being transported from both sides by the oblique wave angles in the circular wave pattern and decreasing wave heights alongshore with penetration into the shadow region. Accurate and efficient calculation of waves transforming under combined diffraction, refraction, and shoaling to breaking is required to obtain realistic predictions of the shoreline change in such situations.

In areas where the waves diffract, Equation 6 is used to calculate the height of the breaking waves that have been transformed by diffraction, refraction, and shoaling,

$$
\mathrm{H}_{\mathrm{b}}=\mathrm{K}_{\mathrm{D}} \mathrm{H}_{\mathrm{b}}^{\prime}
$$

in which

$$
\mathrm{K}_{\mathrm{D}}=\text { diffraction coefficient }
$$

$\mathrm{H}_{\mathrm{b}}=$ breaking wave height at the same cell without diffraction (ft)

Contour modification. The beach plan shape changes as a result of spatial differences in longshore sand transport. The change in the beach shape, in turn, alters the refraction of the waves. This interaction between the beach and waves is represented in GENESIS by using a coordinate system 
rotated to align with the local contours (which change in time) at each calculation point in taking waves from a reference depth to the point of breaking.

Wave energy windows. The concept of wave energy windows is central to GENESIS and determines its algorithmic structure. Wave energy windows provide a powerful means of describing breaking wave conditions and the associated sand transport alongshore for a wide variety of configurations of coastal structures. Energy windows and transport domains are constructs internal to GENESIS and are automatically defined according to model inputs. An energy window is defined as a beach area open to incident waves as viewed from that particular stretch of beach. Operationally, an energy window is defined by two boundaries regarded as limiting the penetration of wave energy to the target beach. Windows are separated by diffracting groins and detached breakwaters. Incident wave energy must enter through one of these windows to reach a location in the nearshore area. It is possible (and common) for a given location to be open to waves from more than one window.

Sand transport calculation domains. In GENESIS, shore-connected structures (jetties, groins, and breakwaters attached to groins) are assumed not to transmit wave energy, so that waves entering on one side of such a structure cannot propagate to the other side. Based on the concept of wave energy windows and non-wave transmissibility of shore-connected structures, the shoreline is divided into what are called "sand transport calculation domains." These domains consist of segments of the coast which are bounded on each side by either a diffracting shore-connected structure or a model boundary. GENESIS solves the shoreline change equation independently for each sand transport domain, except for conditions such as sand passing around or through groins, which allow exchange of sand across the boundaries of the calculation domains.

Wave transmission at detached breakwaters. The design of detached breakwaters for shore protection requires consideration of many factors, including structure length, distance offshore, crest height, core composition, and gap between structures in the case of segmented breakwaters. Wave transmission, a term describing the movement of a wave over and through a structure, occurs in most practical applications. Designing for wave transmission is economical and it is often advantageous from the perspective of beach change control to build low and/or porous structures to allow wave energy penetration.

To describe wave transmission in the modeling system, a transmission coefficient value $\mathrm{K}_{\mathrm{T}}$ must be provided or estimated for each detached breakwater. The transmission coefficient, defined as the ratio of the height of the incident wave directly shoreward of the breakwater to the height directly seaward of the breakwater, has the range $0 \leq \mathrm{K}_{\mathrm{T}} \leq 1$. A value of $\mathrm{K}_{\mathrm{T}}$ equal to 0 implies no transmission and $\mathrm{K}_{\mathrm{T}}=1$ implies complete transmission. All 
breakwaters simulated in this study were assigned a transmission coefficient of 0.5 . This relatively high transmission coefficient was estimated based on the breakwater design which specifies a crest height of $4 \mathrm{ft}$ NGVD, a crest width of $10 \mathrm{ft}$, and that the breakwaters are to be constructed of 2,400 to $6,000 \mathrm{lb}$ armor stone only (no core).

The derivation of the phenomenological wave transmission algorithm in GENESIS was developed on the basis of three criteria:

a. $\quad$ As $\mathrm{K}_{\mathrm{T}}$ approaches zero, the calculated wave diffraction should equal that given by standard diffraction theory for an impermeable, infinitely high breakwater.

b. If two adjacent energy windows have the same $K_{T}$, no diffraction should occur (wave height uniform at the boundary).

c. On the boundary between energy windows with different $\mathrm{K}_{\mathrm{T}}$ values, wave energy should be conveyed from the window with higher waves into the window with smaller waves. The wave energy transferred should be proportional to the ratio between the two transmission coefficients.

The preceding criteria lead to the following expression for modifying the diffraction coefficient $K_{D}$ for non-transmissive breakwaters to obtain a diffraction coefficient $\mathrm{K}_{\mathrm{DT}}$ for transmissive breakwaters,

$$
K_{D T}=\left\{\begin{array}{lr}
K_{D}+R_{K T}\left(1-K_{D}\right) & \text { inside shadow zone } \\
K_{D}-R_{K T}\left(K_{D}-0.5\right) & \text { on border } \\
K_{D}\left(1-R_{K T}\right) & \text { outside shadow zone }
\end{array}\right.
$$

in which $R_{K T}$ is the ratio of the smaller valued transmission coefficient to the larger valued transmission coefficient for two adjacent breakwaters. The terminology "shadow zone" refers to the region shadowed from wave energy by the breakwater with associated value of $K_{\mathrm{DT}}$.

Multiple diffraction. If an energy window is bounded by two sources of wave diffraction, one on the left $(L)$ and one on the right $(R)$, each will have an associated diffraction coefficient, $\mathrm{K}_{\mathrm{DL}}$ and $\mathrm{K}_{\mathrm{DR}}$, respectively. The internal wave transformation model calculates a combined diffraction coefficient $K_{D}$ for the window as:

$$
\mathrm{K}_{\mathrm{D}}=\mathrm{K}_{\mathrm{DL}} \mathrm{K}_{\mathrm{DR}}
$$

The properties of Equation 8 are such that: (a) as $\mathrm{K}_{\mathrm{DL}}$ and $\mathrm{K}_{\mathrm{DR}}$ each approach unity, the total diffraction coefficient approaches unity (situation at a large gap between breakwaters), and (b) the total diffraction coefficient approaches zero as either $\mathrm{K}_{\mathrm{DL}}$ or $\mathrm{K}_{\mathrm{DR}}$ approach zero, (situation deep inside a wave shadow 
zone). If an energy window is open (no diffraction source) on one side, the diffraction coefficient for that side is set equal to 1.0 .

\section{Model Calibration and Verification}

\section{Introduction}

The standard calibration procedure for GENESIS is to determine the magnitude of the transport parameters $\mathrm{K}_{1}$ and $\mathrm{K}_{2}$ by reproducing known shoreline change that occurred at the project between two surveys. If sufficient data are available, the calibrated model is then used to simulate known shoreline change over a time interval not spanned by the calibration simulation. The purpose of a two-part calibration and verification is to verify that the calibration constants assigned in the calibration and held constant in the verification are independent of the time interval. Since long-term directional measured wave data are not available for the project site, a representative 4-year-long time history of hindcast wave conditions was selected, as discussed in Chapter 2. This representative time history of wave information provided the required wave input to drive the model during calibration and verification.

The shoreline change model was calibrated for the time period January 26 , 1985 to June 25, 1990. The verification simulation was performed for the time period 25 June 1990 to 30 August 1992. The digitized shoreline positions used for these simulations are shown in Figure 7. For reference, the origin is located 4,500 $\mathrm{ft}$ southwest of the terminal groin at Barataria Pass and the reach extends a total of $31,900 \mathrm{ft}$ alongshore. Figure 8 shows the measured shoreline positions within the project simulation subreach, the area of primary interest.

Before detailing the model calibration and verification, shoreline changes that occurred during the two periods of interest are discussed. The following shoreline changes are noted for the calibration period, moving from the solid line (depicting the January 1985 shoreline position) to the chain dash line (depicting the June 1990 shoreline position). During this period a pronounced salient formed in the lee of the borrow pit (located approximately $22,000 \mathrm{ft}$ from the origin) excavated for the beach fill which was completed just prior to taking the aerial photographs that were used to determine the 1985 shoreline position. Within the project simulation subreach the 1985 beach nourishment is evidenced by the seaward location of the shoreline in this area. General shoreline erosion is the noted trend of shoreline change for the calibration period. East of the project subreach, accretion of the shoreline is noted. West of the salient, erosion is the observed trend of shoreline change. During the verification period (moving from the chain dash line to the dashed line) erosion is the trend of shoreline change east of the project simulation subreach, minor shoreline accretion is observed within the project simulation subreach, and accretion is the trend of shoreline change west of the salient. 


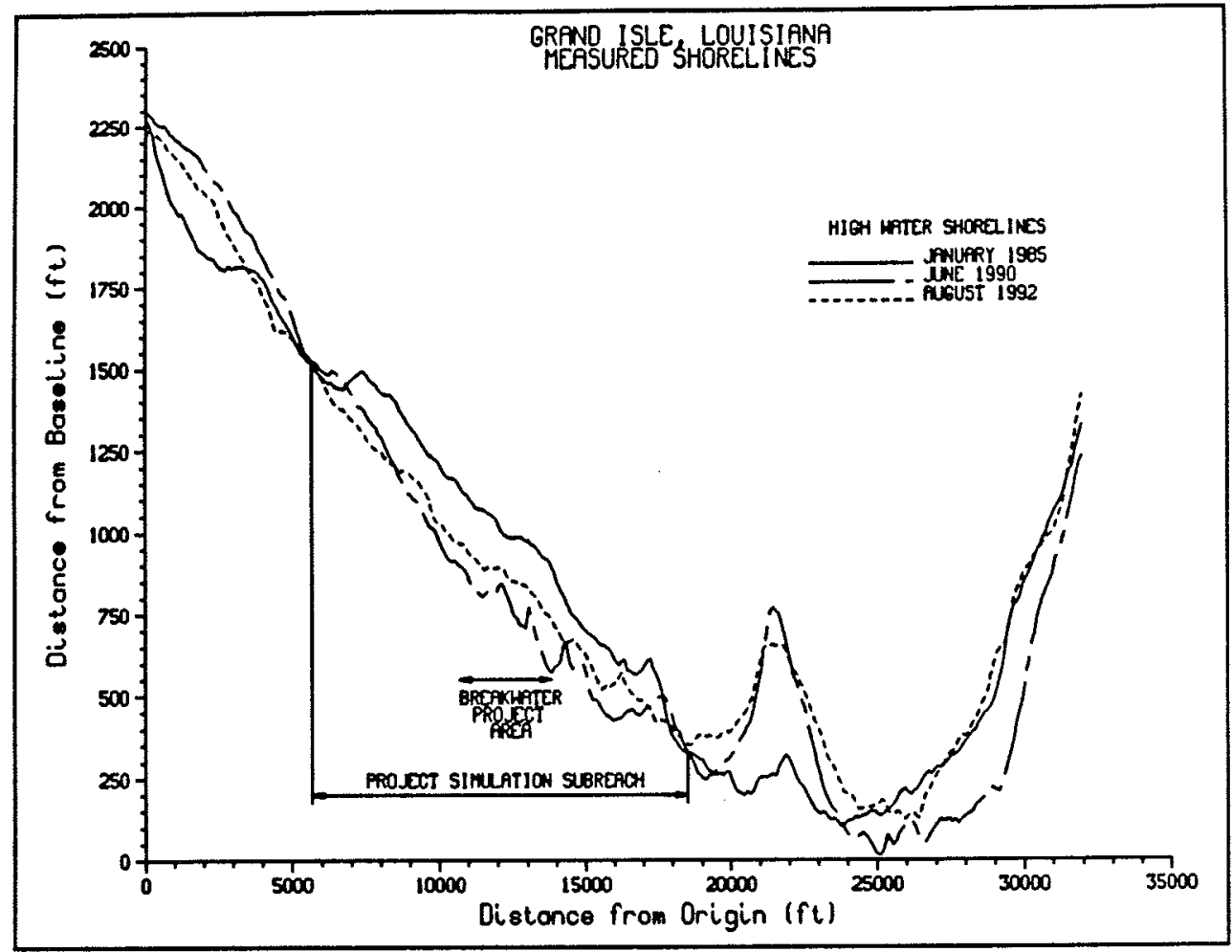

Figure 7. Measured shoreline positions

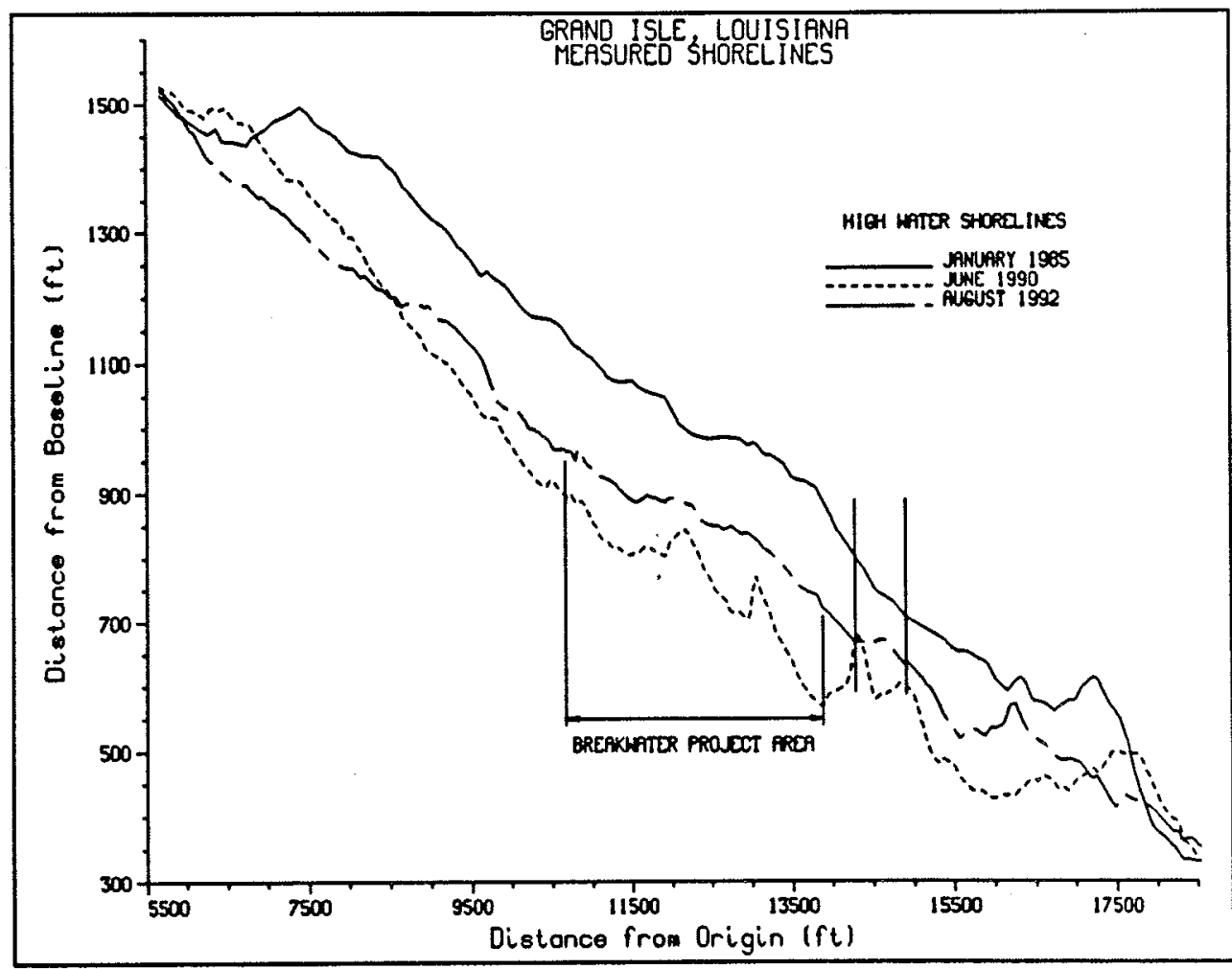

Figure 8. Measured shoreline positions within the project simulation subreach 
Also of interest is the fact that the salient does not continue to accrete but rather begins to disperse. With respect to numerically modeling shoreline change during these two time periods using a representative time series of wave conditions to drive the model, it is acknowledged that apparent reversals in shoreline change trends, particularly west of the salient, will very likely not be well reproduced with the model.

\section{GENESIS calibration}

Calibration simulations were performed for both the entire Grand Isle simulation reach as well as the project subreach. The reason for using a project simulation subreach was to enable resolution of the relatively short length of some of the proposed breakwater segments (the shortest of which were only $100 \mathrm{ft}$ ). In the calibration of the Grand Isle reach, 100-ft grid cells were specified in the model setup requiring a total of 320 calculation cells. The lateral boundary conditions were specified as pinned implying stable shoreline positions at the ends of the modeled reach. For the project simulation subreach, 25 -ft grid cells were used resulting in a total of 515 calculation cells, again pinned beach lateral boundary conditions were specified. A comparison of the final calibration simulation results for both the Grand Isle reach and the project simulation subreach are shown in Figure 9. Figures 10 and 11 show the final calibration results and the average annual longshore sand transport rates, respectively, for the project simulation

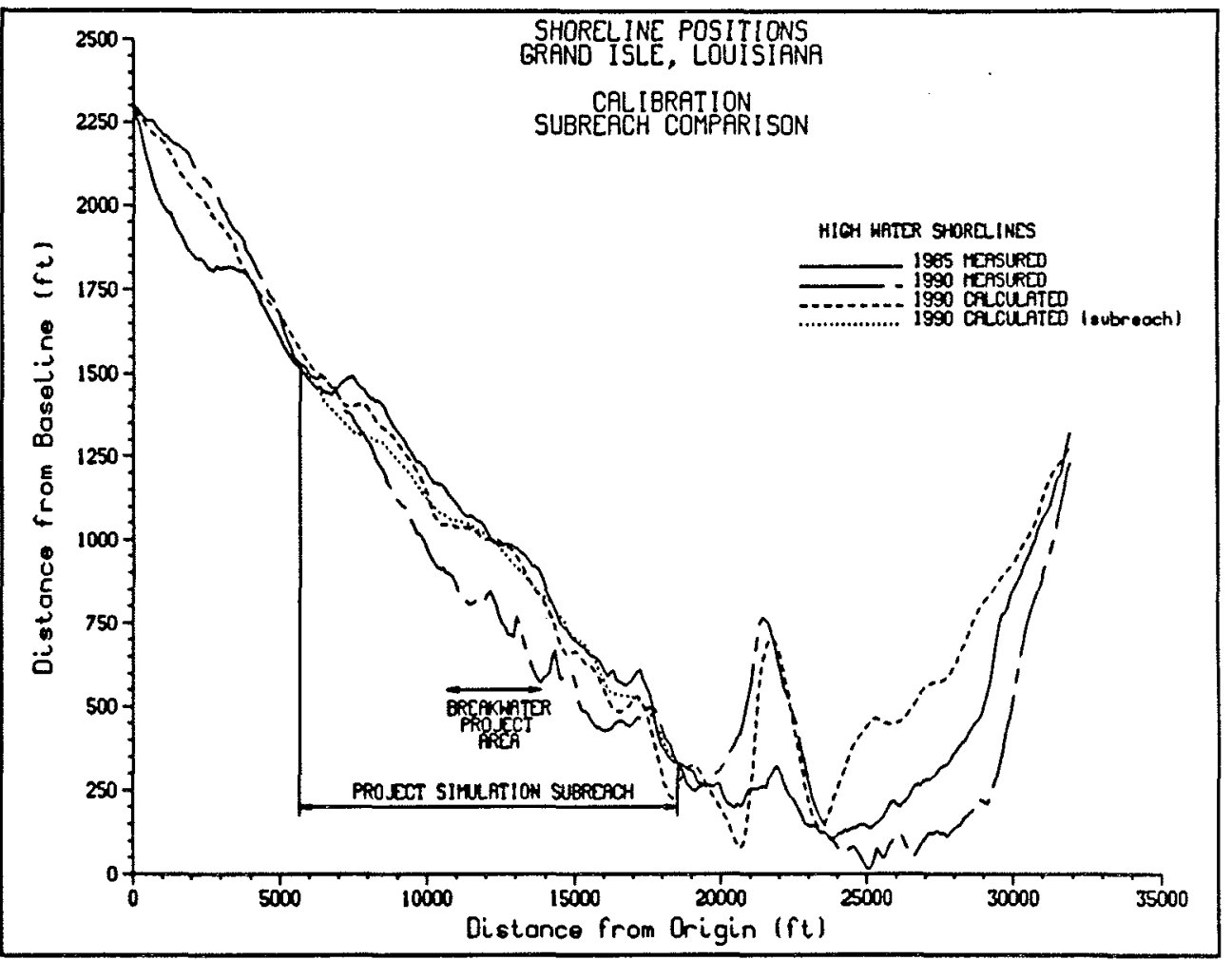

Figure 9. GENESIS calibration (Grand Isle and project subreach) 


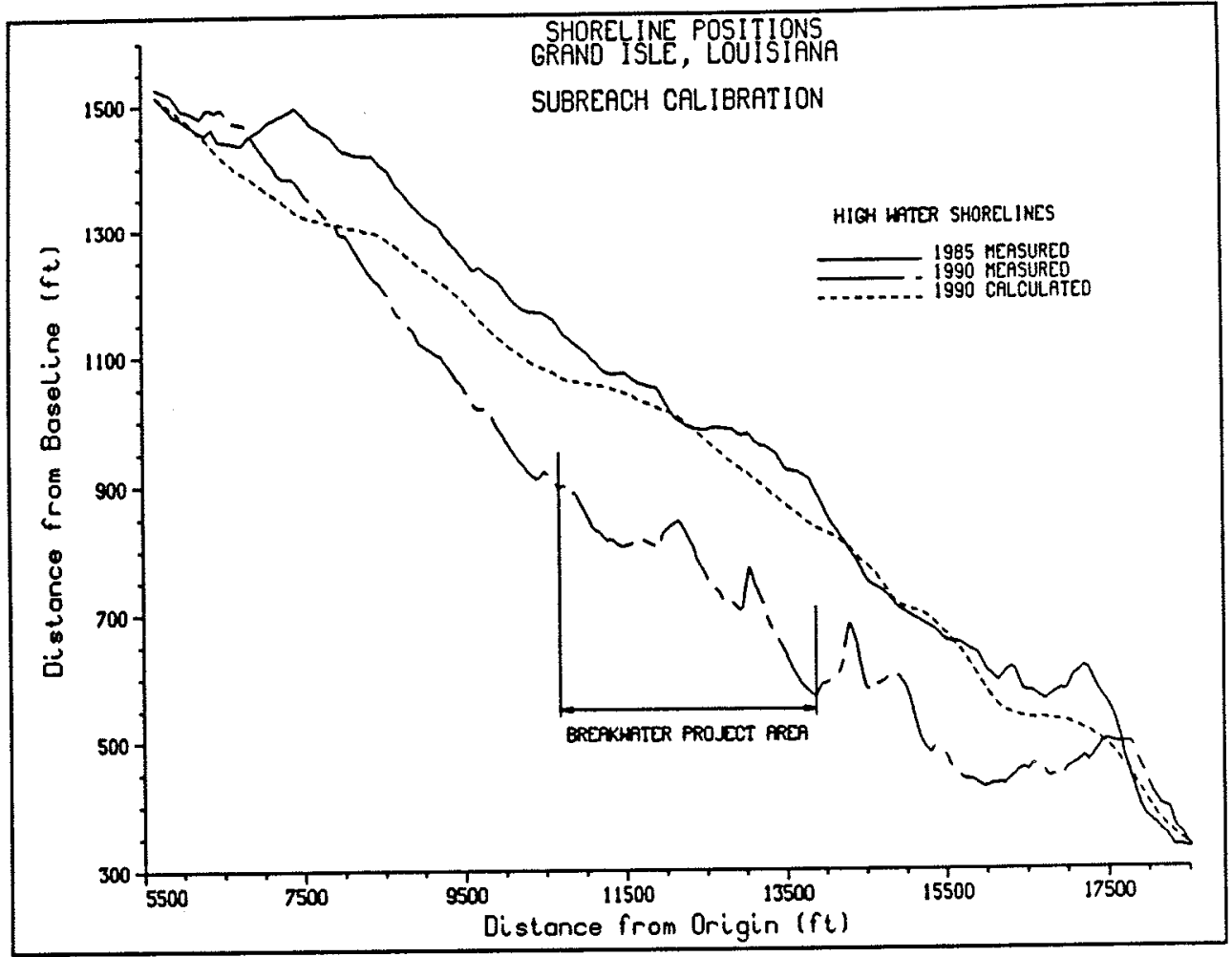

Figure 10. GENESIS calibration (project simulation subreach)

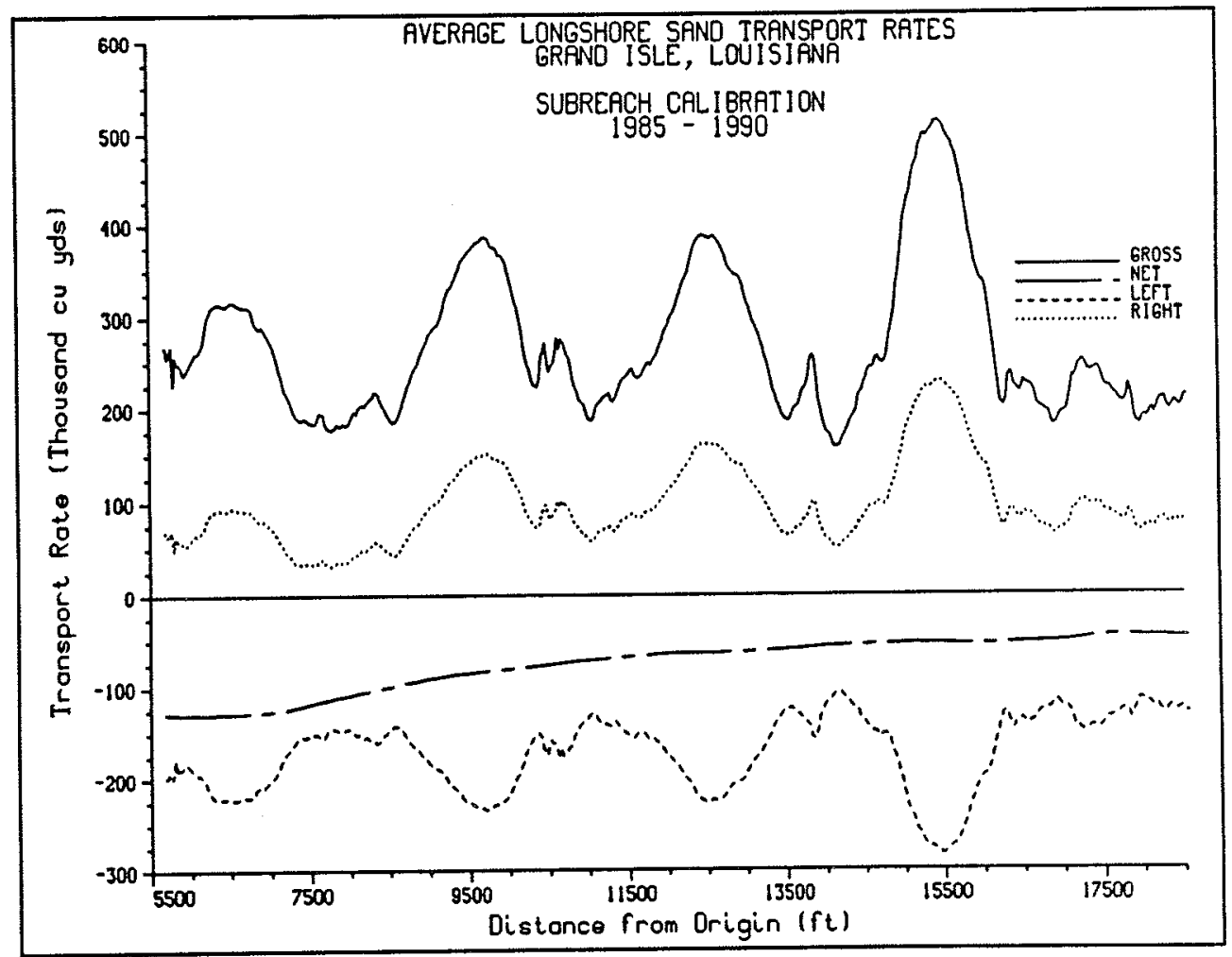

Figure 11. Average annual longshore transport rates (calibration) 
subreach. Numerous trial calibration simulations were made to achieve the results shown in Figures $9-11$ and an overall assessment of the quality of the calibration is less than ideal. The relatively poor comparison between the calculated and measured 1990 shoreline positions is believed to be primarily due to the fact that shoreline change during the calibration period was heavily influenced by the passing of three hurricane events which were not represented in the wave time series used to drive the shoreline change model. These hurricanes included storm surges and severe wave conditions which eroded sand from the beach face and presumably deposited it in offshore regions of the profile. Furthermore, it is believed that the dominant transport that occurs during storms is one of cross-shore sand transport which is not included in the GENESIS model. Consequently, even if concurrent wave data were available it is unlikely that the calibration would substantially improve. This does not, however, preclude use of the model to evaluate future shoreline change at Grand Isle as influenced by the proposed detached breakwater project, but requires that the longshore sand transport regime depicted in Figure 11 be accepted as representative of the longshore transport occurring along the project reach. Figure 11 shows that the net longshore transport is negative indicating transport from the southwest to the northeast along the project reach. The estimated rate of sand transport increases from approximately $50,000 \mathrm{yd}^{3} /$ year just east of the salient to approximately $125,000 \mathrm{yd}^{3} /$ year approximately $10,125 \mathrm{ft}$ southwest of the terminal groin at Barataria Pass. This description of the net longshore sand transport rate compares well with the description of longshore sand transport processes provided in the Grand Isle and vicinity, General Design Memorandum (U.S. Army Corps of Engineers 1979).

The values assigned (through the calibration process) to the calibration parameters $K_{1}$ and $K_{2}$ were 0.8 and 2.4 , respectively. Note that the value of $\mathrm{K}_{2}$ is well outside of the normal range for this parameter $\left(0.5 \mathrm{~K}_{1} \leq \mathrm{K}_{2} \leq 1.0\right.$ $\mathrm{K}_{1}$ ). This large value of $\mathrm{K}_{2}$ was required to simulate the formation of the salient in the lee of the dredged borrow pit. The process occurring at this location is hypothesized as one caused by a large scale horizontal circulation pattern induced by wave transformation over the borrow pit. As waves move over the borrow pit they are refracted away from the hole to shallower water adjacent to the hole (i.e., wave crests diverge away from the borrow pit). The result of this transformation is a substantial decrease in wave energy directly landward of the borrow pit in conjunction with an increase in wave energy to the sides of the borrow pit. This gradient in wave energy, relatively calm water or a low energy surf zone with high energy surf zones on both sides of the pit, sets up a circulation that carries material suspended in the high energy zones toward the low energy surf zone where the material is deposited and builds the salient. Horikawa et. al. 1977, concluded (from physical and mathematical modeling experiments) that the major effect on shoreline change due to dredged holes in the nearshore zone is the formation of a salient behind the hole together with erosion of adjacent shorelines. Within GENESIS, a salient does not develop behind the dredged hole for normal values of the $\mathrm{K}_{2}$ parameter because landward of the borrow pit wave 
angles diverge away from the borrow pit, and it is the breaking wave angle that determines the direction of sand transport using Equation 3.

Consequently, the second term in Equation 3 (the alongshore wave height gradient term) had to be increased to the point where it dominated the direction of littoral transport in order to enable the model to simulate the formation of the salient in the lee of the dredged borrow pit. This large value of $\mathrm{K}_{2}$ was found to cause the numerical solution to become unstable during simulations that included detached breakwaters, thus the value of $K_{2}$ had to be reduced in the breakwater design alternative simulations. The sensitivity of the model solutions to the value of $\mathrm{K}_{2}$ was investigated in the verification simulations as discussed in the next section.

\section{GENESIS verification}

Verification simulations were performed for the approximate two year period between June 1990 and August 1992. Again simulations were performed for both the Grand Isle reach and the project subreach. In this phase of preparing the model for evaluating the proposed detached breakwater configurations, the calibration parameters $K_{1}$ and $K_{2}$ were held to the values determined during the calibration simulations. Permeability factors for the two groins bounding the town of Grand Isle breakwater project were varied to achieve the observed shoreline change. The four breakwaters between the groins were not modeled due to their short length (approximately $75 \mathrm{ft}$ ) which could not be adequately resolved using a $25-\mathrm{ft}$ grid cell spacing, and because a low tide tombolo had formed behind them during the verification period. The GENESIS model cannot be used to simulate shoreline change in the vicinity of breakwaters once a tombolo has formed. The intention here was to capture the influence (presumed to be a moderate interruption of the longshore sand transport rate) of the town of Grand Isle breakwater project as a whole, but not necessarily in detail. Consequently, only the two groins bounding the project were actually modeled with GENESIS.

Figure 12 shows the results of the final verification simulation of the Grand Isle reach together with the verification results of the project simulation subreach. It is evident that the comparison between the calculated and measured shoreline positions is quite good and also that the same solution is effectively obtained whether the whole Grand Isle reach is modeled or just the project simulation subreach is modeled. These simulations do not include the effects of the additional material placed on the beach during the 1990 Grand Isle beach rehabilitation project. Figure 13 shows the results of the final verification simulation for the project simulation subreach and includes effect of the placement of approximately $500,000 \mathrm{yd}^{3}$ of beach fill within the reach. The corresponding average annual longshore sand transport rates are given in Figure 14. It is seen in Figure 14 that the inclusion of the beach fill volumes associated with the 1990 Grand Isle rehabilitation project improves the already satisfactory results within the project subreach. 


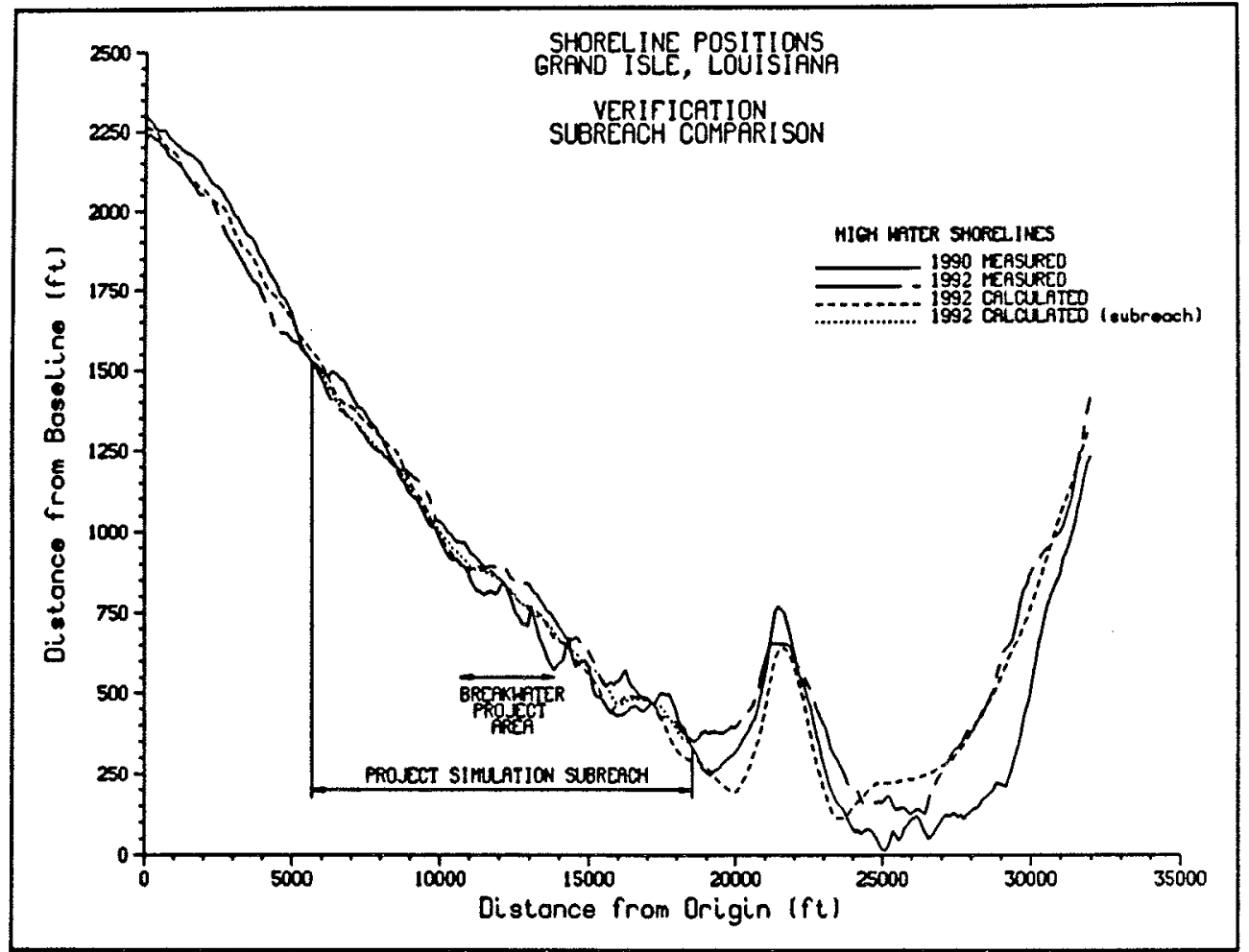

Figure 12. GENESIS verification (Grand Isle and project subreach)

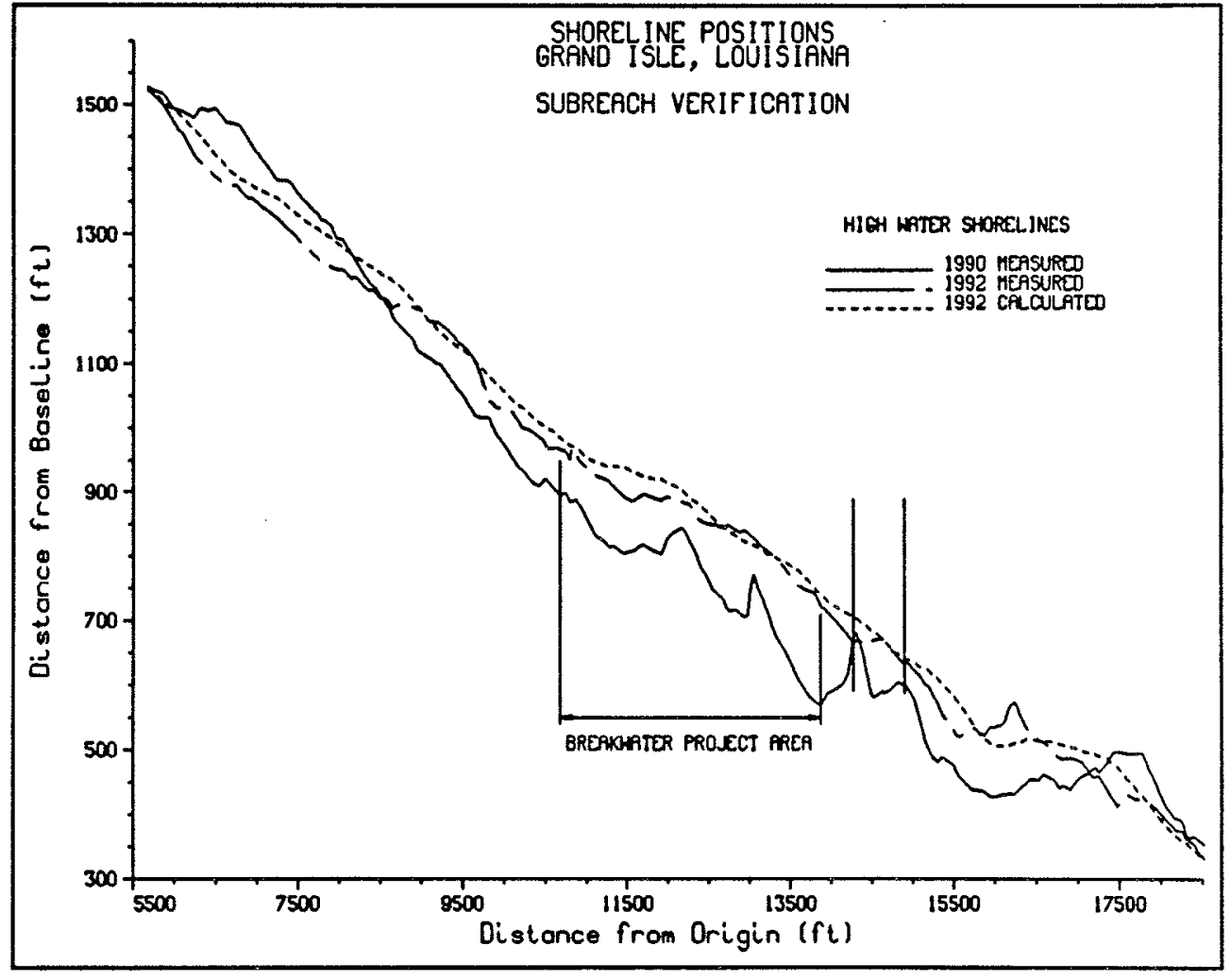

Figure 13. GENESIS verification (Project subreach with $500,000 \mathrm{yd}^{3}$ beach fill) 


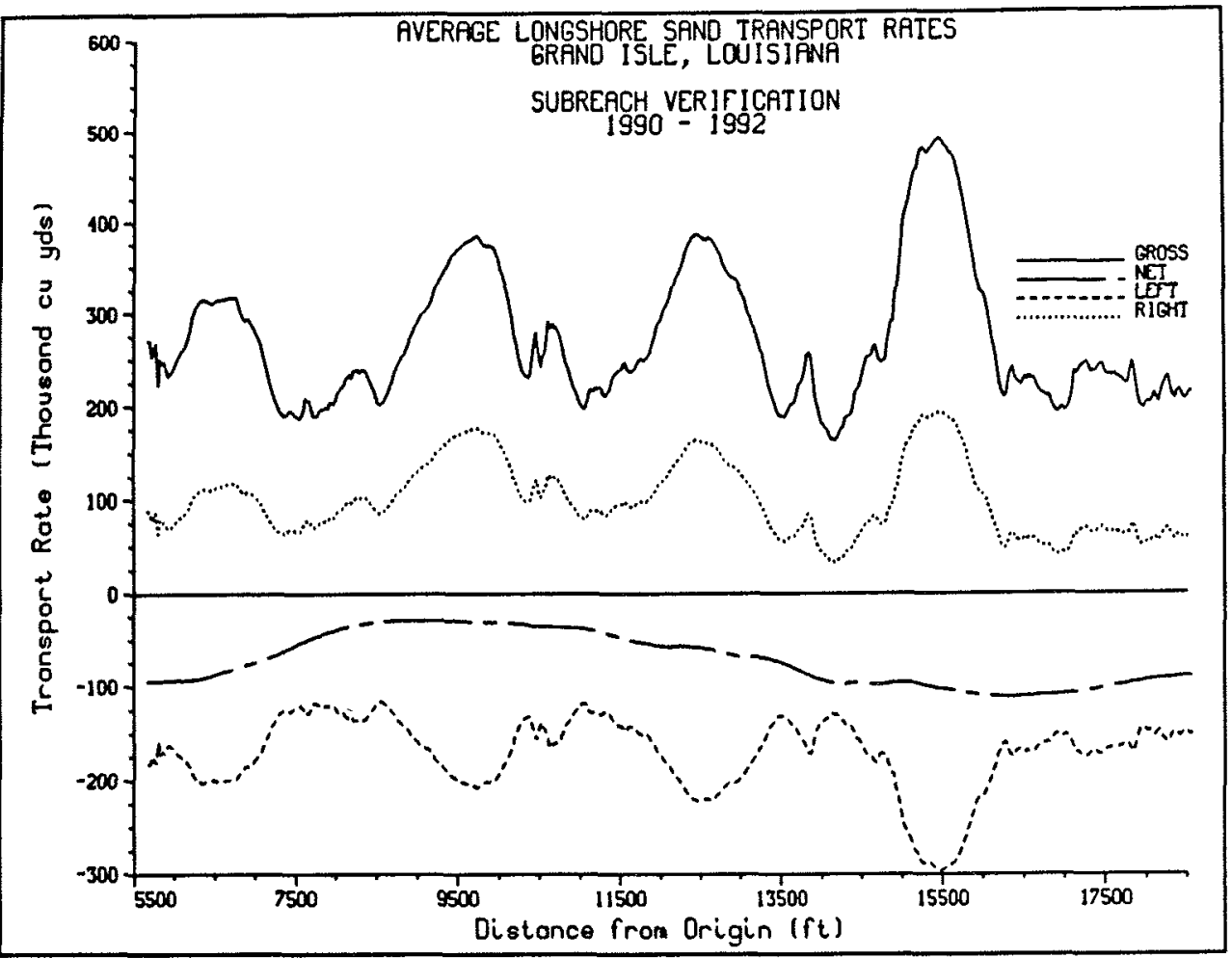

Figure 14. Average longshore sand transport rates (verification)

At this point in the study numerical simulations of various proposed detached breakwater configurations were initiated. In these simulations severe numerical instability problems were encountered, and it was determined that the instability was caused by the unusually large value of $\mathrm{K}_{2}$. After more tests it was determined that instability would not be a problem if the value assigned to $\mathrm{K}_{2}$ was within the normal range of $0.5 \mathrm{~K}_{1} \leq \mathrm{K}_{2} \leq 1.0 \mathrm{~K}_{1}$. Before continuing the breakwater project evaluation simulations, several more verification simulations were performed to investigate the effect of reducing the value of $K_{2}$. The purpose of these simulations was to gain a better understanding of the sensitivity of model predictions to the value of $\mathrm{K}_{2}$ and to determine if significant wave height gradients exist along other parts of the Grand Isle shoreline particularly within the project simulation subreach.

Figure 15 shows the results of these sensitivity simulations where the value of $\mathrm{K}_{2}$ was varied from $0.5 \mathrm{~K}_{1}$ to $3 \mathrm{~K}_{1}$. As seen in Figure 15 , the predicted shoreline position away from the salient, is almost identical regardless of the value of $\mathrm{K}_{2}$. This result indicates that significant alongshore gradients in wave height are present only in the vicinity of the salient and that model predictions in areas where alongshore gradients do not exist or are small are basically independent of the value of $\mathrm{K}_{2}$. With this understanding, it was decided to proceed with the evaluation of proposed breakwater configurations using $\mathrm{K}_{2}$ equal to 0.4 and 0.8 (bounding the normal range as related to the value of $K_{1}$ ) meaning that each of the proposed breakwater configurations would be simulated twice, once with $\mathrm{K}_{2}$ assigned a value of 0.4 and again with $\mathrm{K}_{2}$ assigned a value of 0.8 . The intention is to provide a range of solutions 


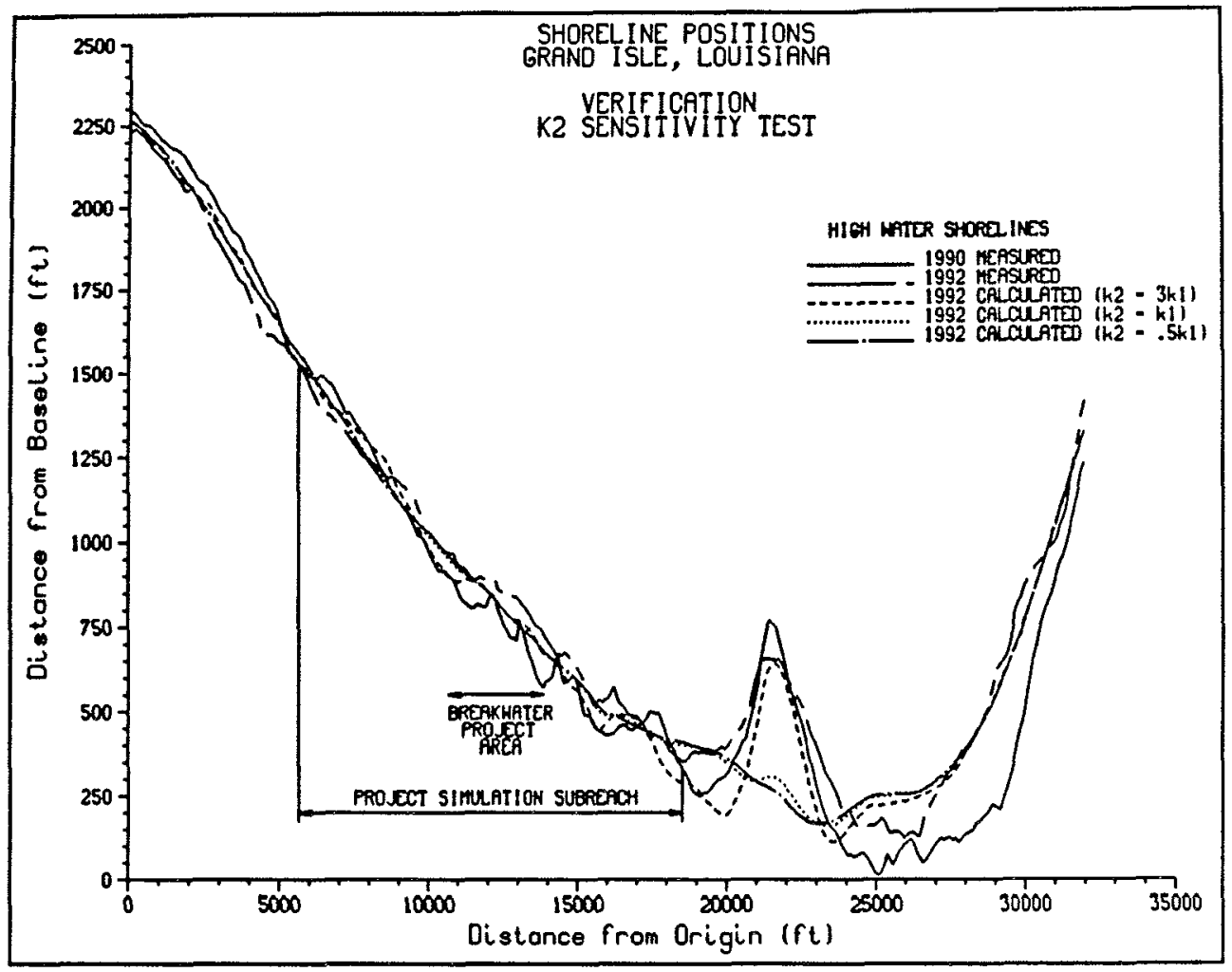

Figure 15. $K_{2}$ sensitivity test simulations

because of the uncertainty associated with the value of $K_{2}$. The following insight concerning shoreline evolution along Grand Isle was obtained from this exercise. The observed shoreline evolution in the vicinity of the dredged borrow pit together with the description of the processes that caused the evolution to occur indicates that shoreline change along Grand Isle may be very sensitive to longshore gradients in breaking waves and other factors that induce systematic nearshore circulation patterns.

\section{Evaluation of Alternative Breakwater Configurations}

\section{Introduction}

A total of 12 different segmented breakwater configurations (developed by LMN) were simulated using the calibrated and verified GENESIS model. Design parameters that were held constant for all breakwater configurations are the distance from the mhw shoreline to the breakwaters which was set to $600 \mathrm{ft}$, the water depth at the breakwater tips which was set to $6 \mathrm{ft}$, and the transmission coefficient assigned to each breakwater which was set to 0.5 . Design parameters that varied were segment lengths which varied between 100 and $300 \mathrm{ft}$, gap spacings which varied between 100 and $400 \mathrm{ft}$, and the total 
number of breakwater segments which varied between 5 and 14 segments. Table 5 summarizes the configuration of the 9 original breakwater design alternatives. The columns labeled LsE and LsW refer to the length of the eastern most breakwater segment and the western most breakwater segment, respectively. Values in these columns are provided only if the lengths of these segments differ from the other breakwater segments. Likewise, the columns labeled $\mathrm{LgE}$ and $\mathrm{LgW}$ refer to the width of the gap between the eastern most breakwater segment and the adjacent breakwater and width of the gap between the western most breakwater and the adjacent breakwater, respectively. Note from Table 5, that breakwater design configurations A, B, and $\mathrm{C}$ each have seven 200 -ft-long breakwater segments and differ only in the gap width between the breakwater structures. Breakwater design configurations $\mathrm{D}$ and $\mathrm{E}$ are variants of configuration $\mathrm{C}$ where the outer most gap widths are increased from $250 \mathrm{ft}$ (configuration $\mathrm{C}$ ) to $400 \mathrm{ft}$ (configuration

\begin{tabular}{|c|c|c|c|c|c|c|c|}
\hline \multicolumn{8}{|c|}{$\begin{array}{l}\text { Table } 5 \\
\text { Grand Isle Proposed Breakwater Configurations* }\end{array}$} \\
\hline \multirow{2}{*}{$\begin{array}{l}\text { Breakwater } \\
\text { Design } \\
\text { Configuration }\end{array}$} & \multirow{2}{*}{$\begin{array}{l}\text { Number of } \\
\text { Segments }\end{array}$} & \multicolumn{3}{|c|}{ Segment Length $(t t)^{* *}$} & \multicolumn{3}{|c|}{ Gap Width $(f t)^{* * *}$} \\
\hline & & LsE & Ls & LsW & $\operatorname{Lg} E$ & $\mathrm{Lg}$ & LgW \\
\hline$A$ & 7 & - & $\begin{array}{l}200 \\
\text { (7) }\end{array}$ & - & - & $\begin{array}{l}150 \\
(6)\end{array}$ & - \\
\hline B & 7 & - & $\begin{array}{l}200 \\
(7)\end{array}$ & - & - & $\begin{array}{l}200 \\
(6)\end{array}$ & - \\
\hline$c$ & 7 & - & $\begin{array}{l}200 \\
\text { (7) }\end{array}$ & - & - & $\begin{array}{l}250 \\
(6)\end{array}$ & - \\
\hline D & 7 & - & $\begin{array}{l}200 \\
(7)\end{array}$ & - & $400(1)$ & $\begin{array}{l}250 \\
(4)\end{array}$ & $\begin{array}{l}400 \\
\text { (1) }\end{array}$ \\
\hline E & 7 & - & $\begin{array}{l}200 \\
(7)\end{array}$ & - & $300(1)$ & $\begin{array}{l}250 \\
(4)\end{array}$ & $\begin{array}{l}300 \\
\text { (1) }\end{array}$ \\
\hline $\mathbf{F}$ & 6 & $200(1)$ & $\begin{array}{l}250 \\
14)\end{array}$ & $\begin{array}{l}200 \\
(1)\end{array}$ & $300(1)$ & $\begin{array}{l}250 \\
(3)\end{array}$ & $\begin{array}{l}300 \\
(1)\end{array}$ \\
\hline G & 5 & $250(1)$ & $\begin{array}{l}300 \\
(3)\end{array}$ & $\begin{array}{l}250 \\
(1)\end{array}$ & - & $\begin{array}{l}300 \\
(4)\end{array}$ & - \\
\hline$H$ & 14 & - & $\begin{array}{l}100 \\
(14)\end{array}$ & - & - & $\begin{array}{l}100 \\
(13)\end{array}$ & - \\
\hline 1 & 14 & - & $\begin{array}{l}100 \\
(14)\end{array}$ & - & $200(1)$ & $\begin{array}{l}100 \\
(11)\end{array}$ & $\begin{array}{l}200 \\
\text { (1) }\end{array}$ \\
\hline \multicolumn{8}{|c|}{$\begin{array}{l}\text { All configurations represent structures in } 6 \mathrm{ft} \text { of water, oriented parallel to trend of } \\
\text { shoreline, located approximately } 600 \mathrm{ft} \text { offshore from the mhw shoreline, and centered } \\
\text { approximately } 2,000 \mathrm{ft} \text { east of the Town of Grand Isle breakwater and groin project. } \\
\text { " If all segment lengths are equal, only } L \text { is given; the number of segments of each } \\
\text { length is given in parenthesis. } \\
\text { * If all gap distances are equal, only } L_{0} \text { is given; the number of gaps with the listed } \\
\text { distance is given in parenthesis. }\end{array}$} \\
\hline
\end{tabular}


D) and $300 \mathrm{ft}$ (configuration E). Design configurations $\mathrm{F}$ and $\mathrm{G}$ examine the use of fewer, but, longer breakwater segments with approximately the same gap widths (configuration $F$ ) and with longer gap widths (configuration $G$ ). Breakwater design configurations $\mathrm{H}$ and $\mathrm{I}$ examine the use of smaller breakwater segments with smaller gap widths. It may also be noted that the cumulative length of breakwater structure $(1,400 \mathrm{ft})$ is constant for all of the proposed configurations.

\section{2-year-duration simulations}

Initially, a series of 2-year-duration shoreline change forecast simulations were performed for each of the proposed breakwater design configurations listed in Table 5. To extract the project impacts and to provide a baseline for comparison, a similar 2-year-duration shoreline change forecast simulation was performed for the "without-project" condition. The results of these simulations are summarized in the following paragraphs. The August 1992 shoreline position was used as the initial shoreline position for these and all other shoreline change forecast simulations.

Figure 16 shows the forecast shoreline position for the without-project condition. Denoted in this figure by the solid line is the initial shoreline position (taken as the August 1992 mhw shoreline position), the seaward-most and landward-most shoreline positions are shown as the dotted lines, and the

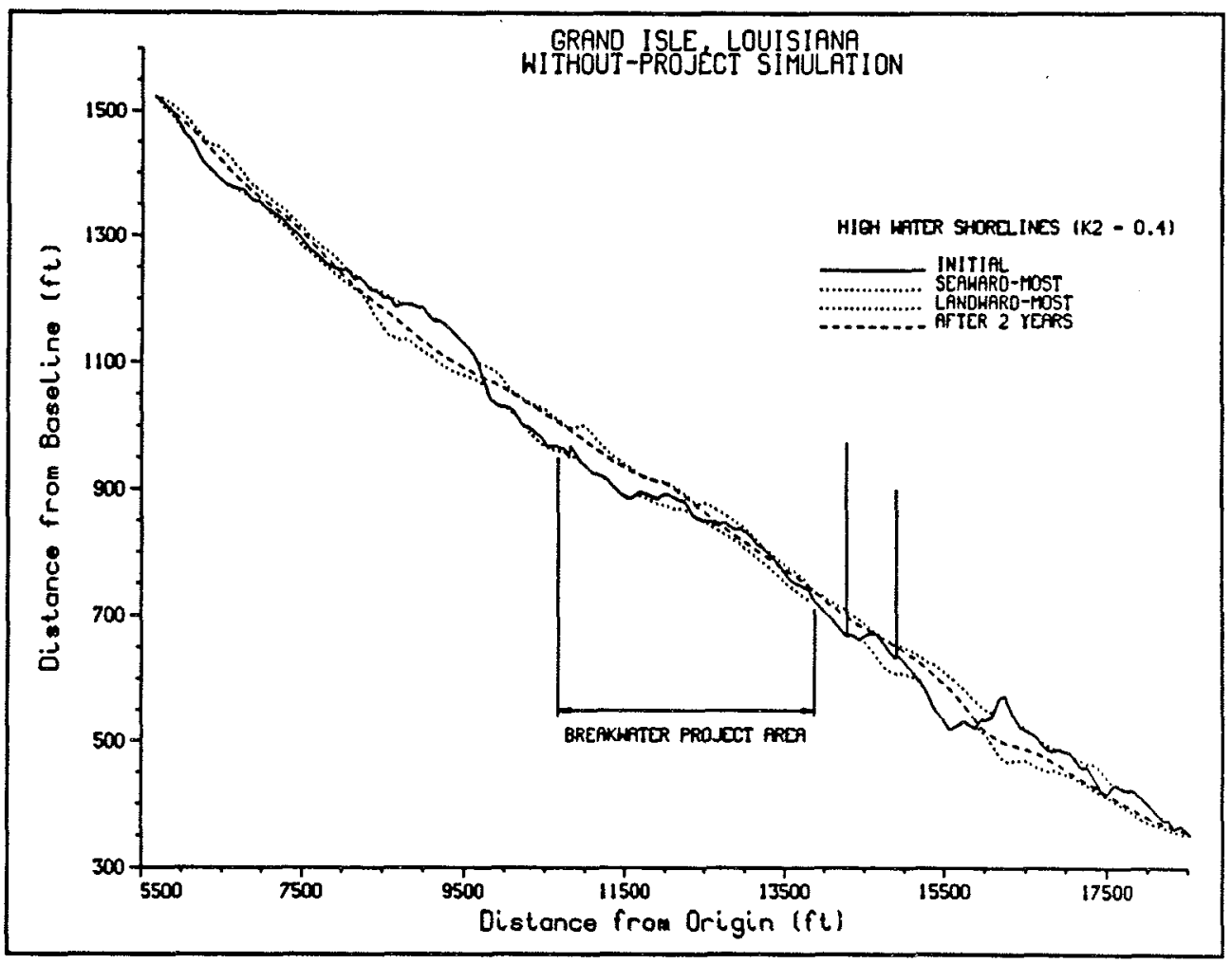

Figure 16. Without-Project shoreline change forecast (2-year simulation) 
final calculated shoreline position is plotted with a dashed line. The results of the project simulations are provided (in an identical format) in Figures 17 through 25. The seaward-most and landward-most shoreline positions, depicted as the dotted lines, in Figures 16 through 25 represent the seawardmost and landward-most position that occurred at each grid cell during the simulation and represents the total excursion of the shoreline for that given cell over the simulation period.

In Figure 16, it is seen that for the without-project condition the model predicts that the shoreline will generally tend to smooth-out but remain basically stable. The apparent stability of the shoreline within the project subreach leads one to question the need for a system of breakwaters in the first place, however, shoreline changes since the 1992 survey indicate that focused shoreline erosion is occurring in a region located approximately $2,000 \mathrm{ft}$ northeast of the town of Grand Isle breakwater and groin project. This region of focused shoreline erosion was observed during a site inspection conducted in January 1993, and was evidenced by substantial dune scarping and the loss of a dune crossover structure.

The predicted shoreline change for the various proposed breakwater design configurations (Figures 17 - 25) show that a system of segmented detached breakwaters constructed offshore will have a significant impact on future shoreline change along the gulfward shoreline of Grand Isle. This impact can, in general, be characterized as one of significant shoreline accretion directly in the lee of the breakwaters coupled with shoreline erosion downdrift (to the east) and moderate shoreline accretion updrift (to the west) of the project.

Other general observations that can be made are:

a. When the width of the gap between the breakwater segments is less than or equal to approximately $200 \mathrm{ft}$ (design configurations $\mathrm{A}, \mathrm{B}, \mathrm{H}$, and I), the accretion of the shoreline behind the system of breakwater evolves as a unit with little sinuosity. In these cases it appears that the system of breakwaters function basically as a single unit and the individual breakwater effects are masked by the total system. This results from the gap being so narrow that significant wave energy does not penetrate through the gap and impinge on the shoreline.

b. When the width of the gap between the breakwater exceeds $200 \mathrm{ft}$ (design configurations C, D, E, F, and G), the shoreline behind the system of breakwaters evolves more as individual salients behind each of the breakwater segments.

c. When the gap width exceeds approximately $250 \mathrm{ft}$ (design configuration $G$ ), some shoreline erosion is observed landward of the gaps.

d. Some downdrift erosion is apparent in all of the with project simulations. This should be expected since breakwaters function to 


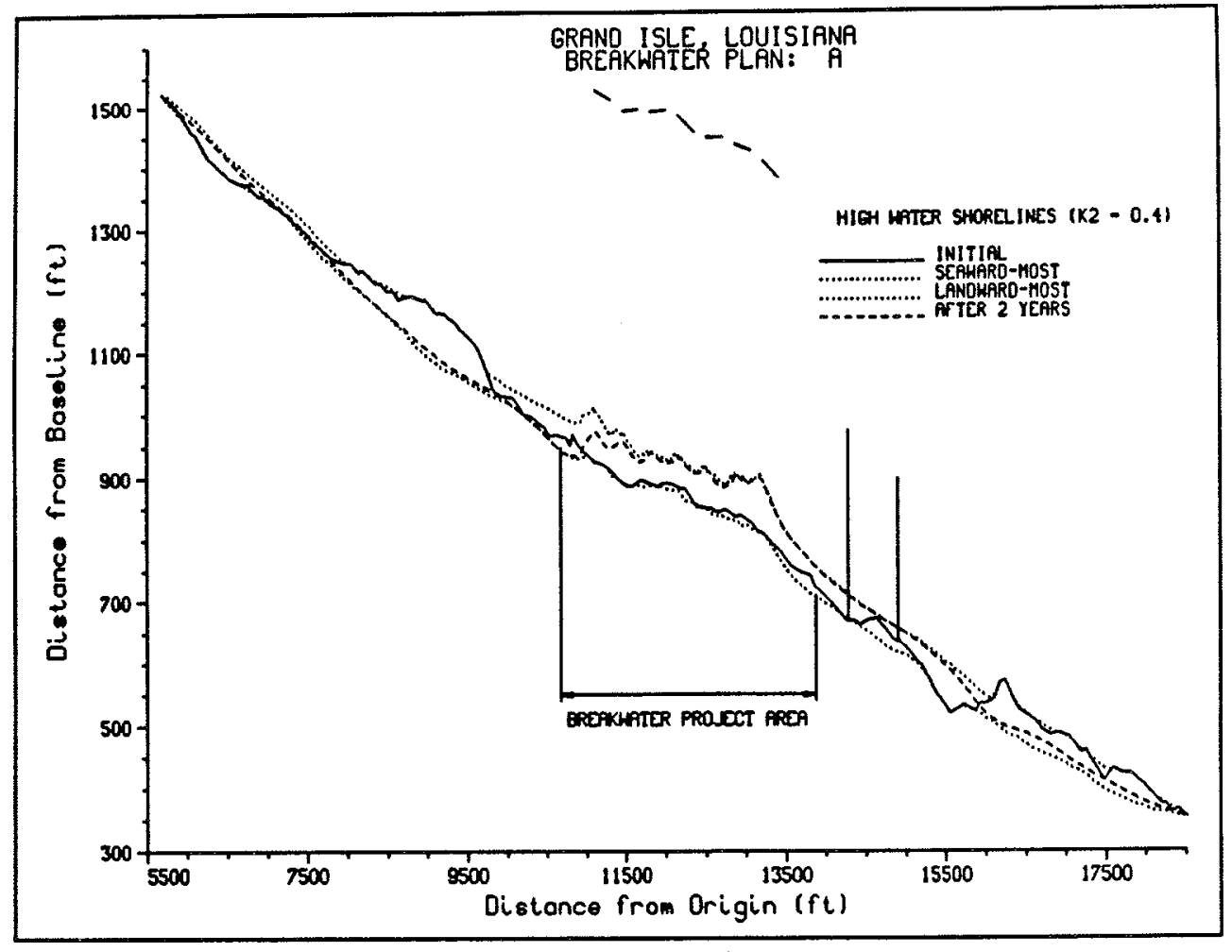

Figure 17. Breakwater design configuration A (2-year simulation)

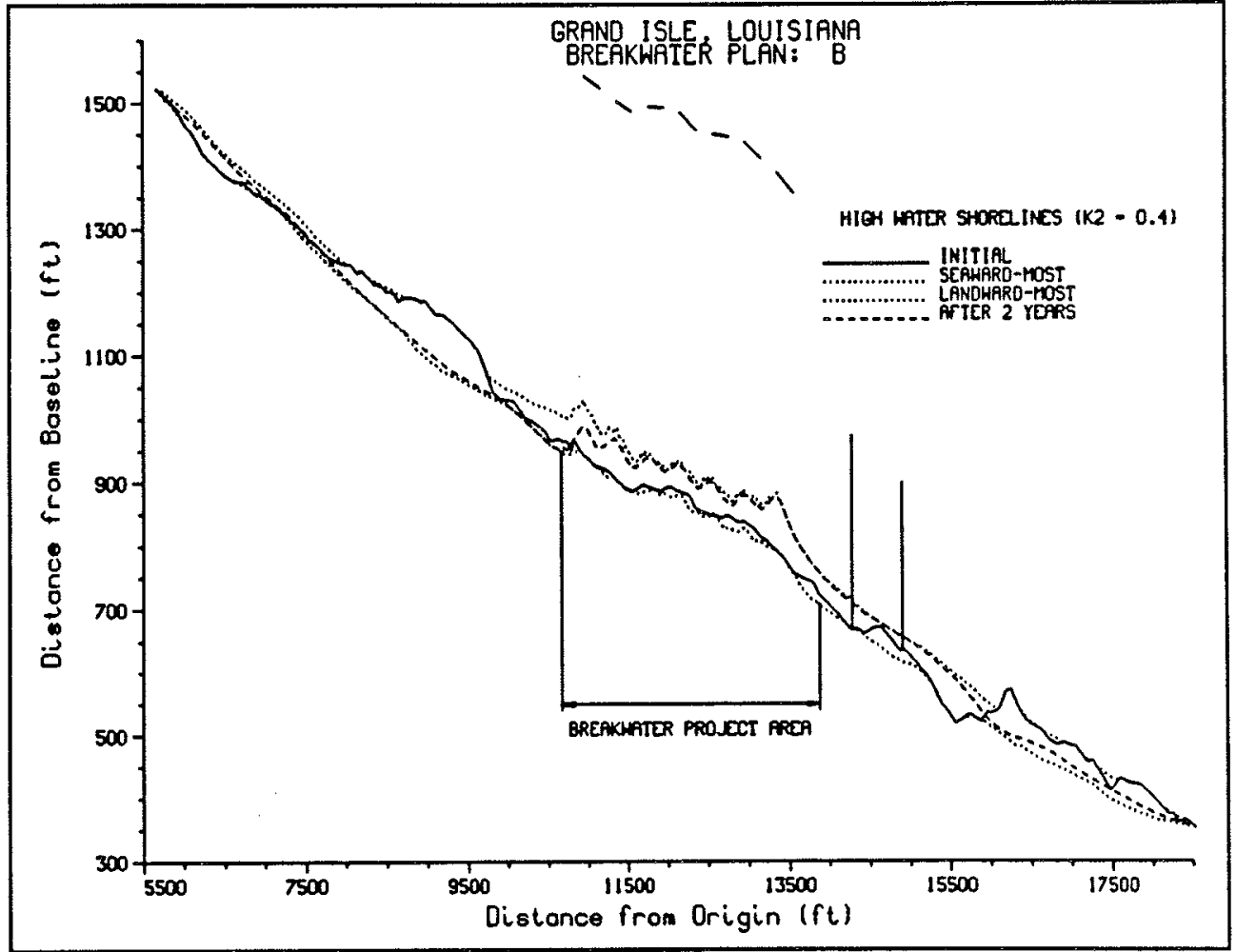

Figure 18. Breakwater design configuration B (2-year simulation) 


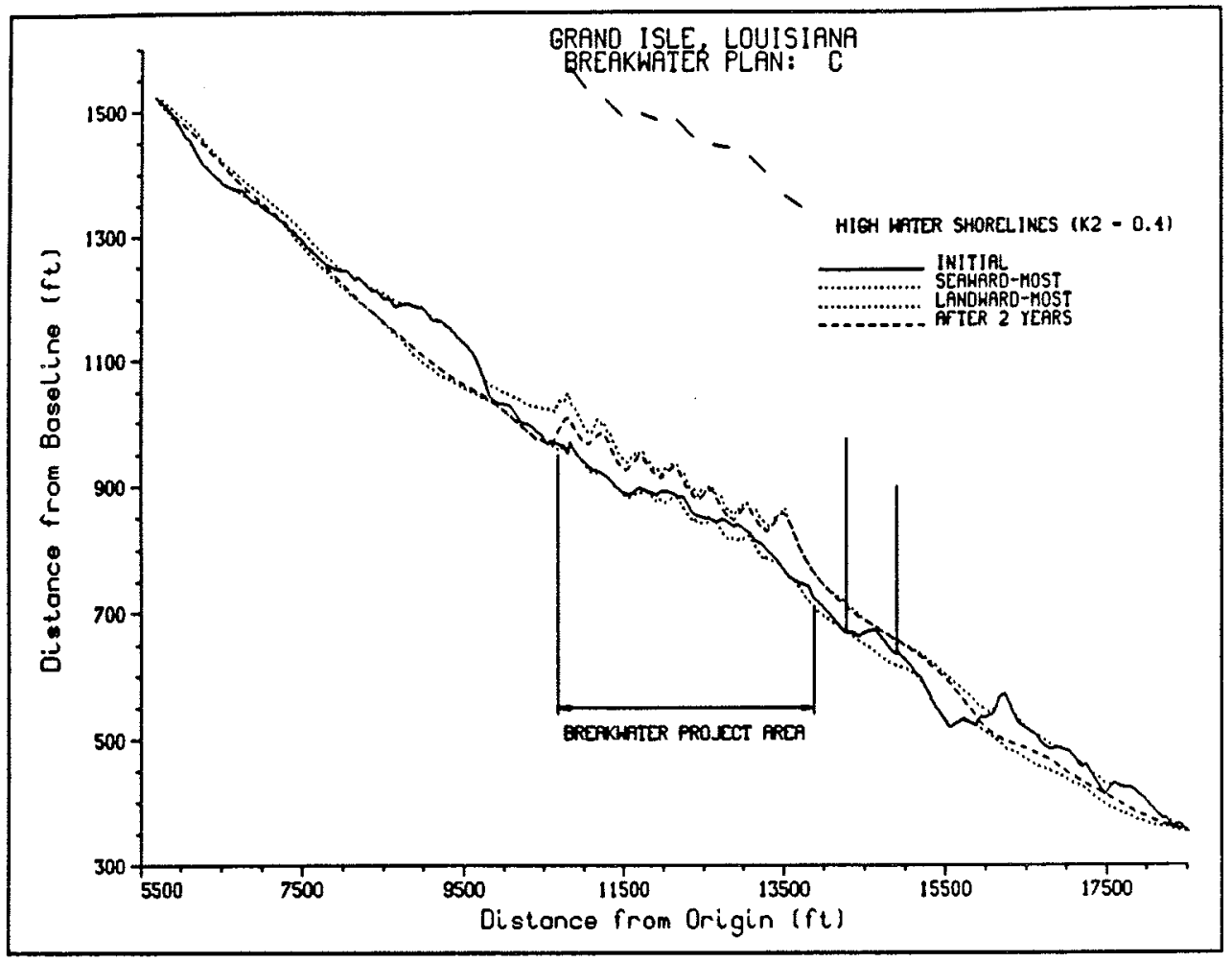

Figure 19. Breakwater design configuration C (2-year simulation)

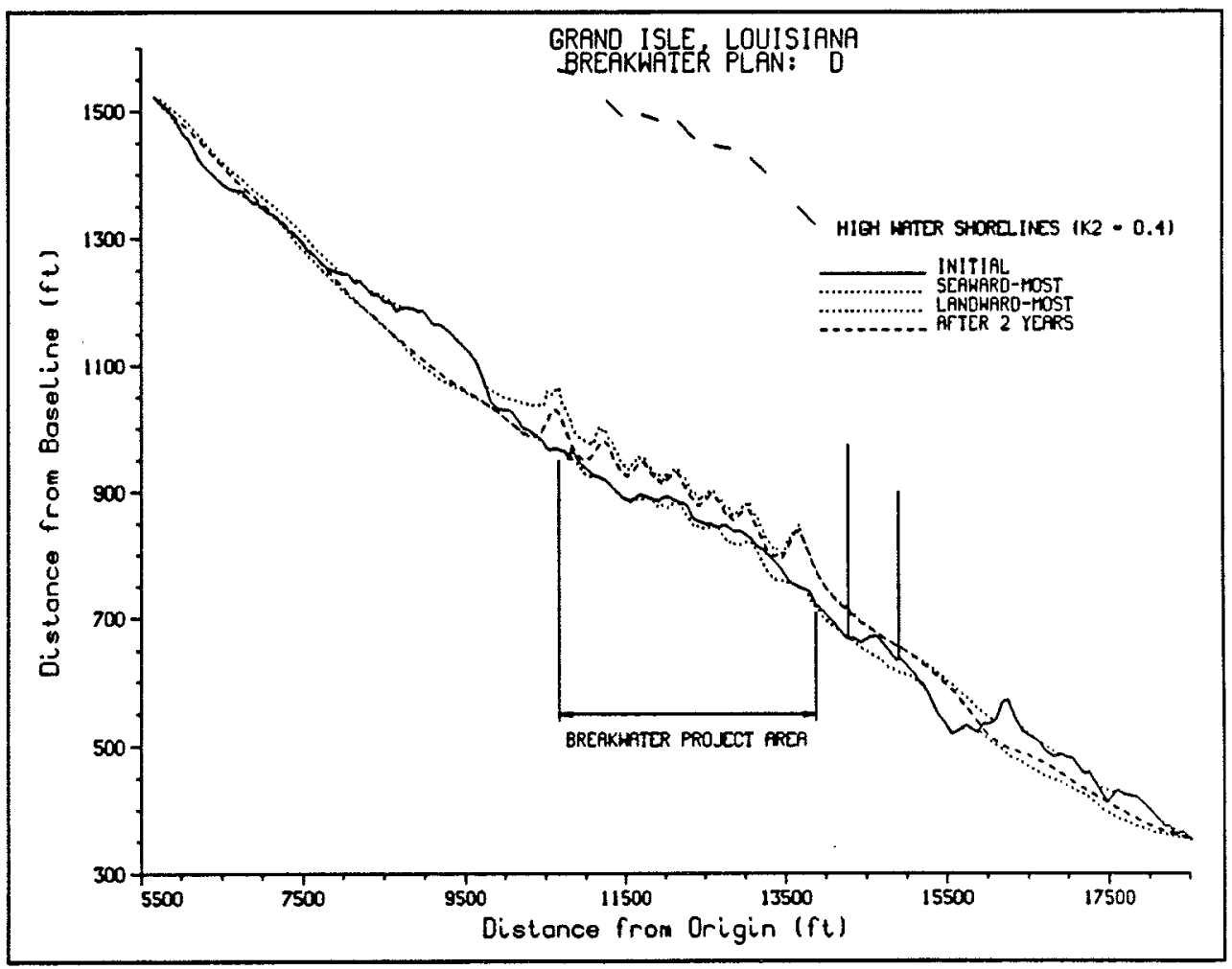

Figure 20. Breakwater design configuration D (2-year simulation) 


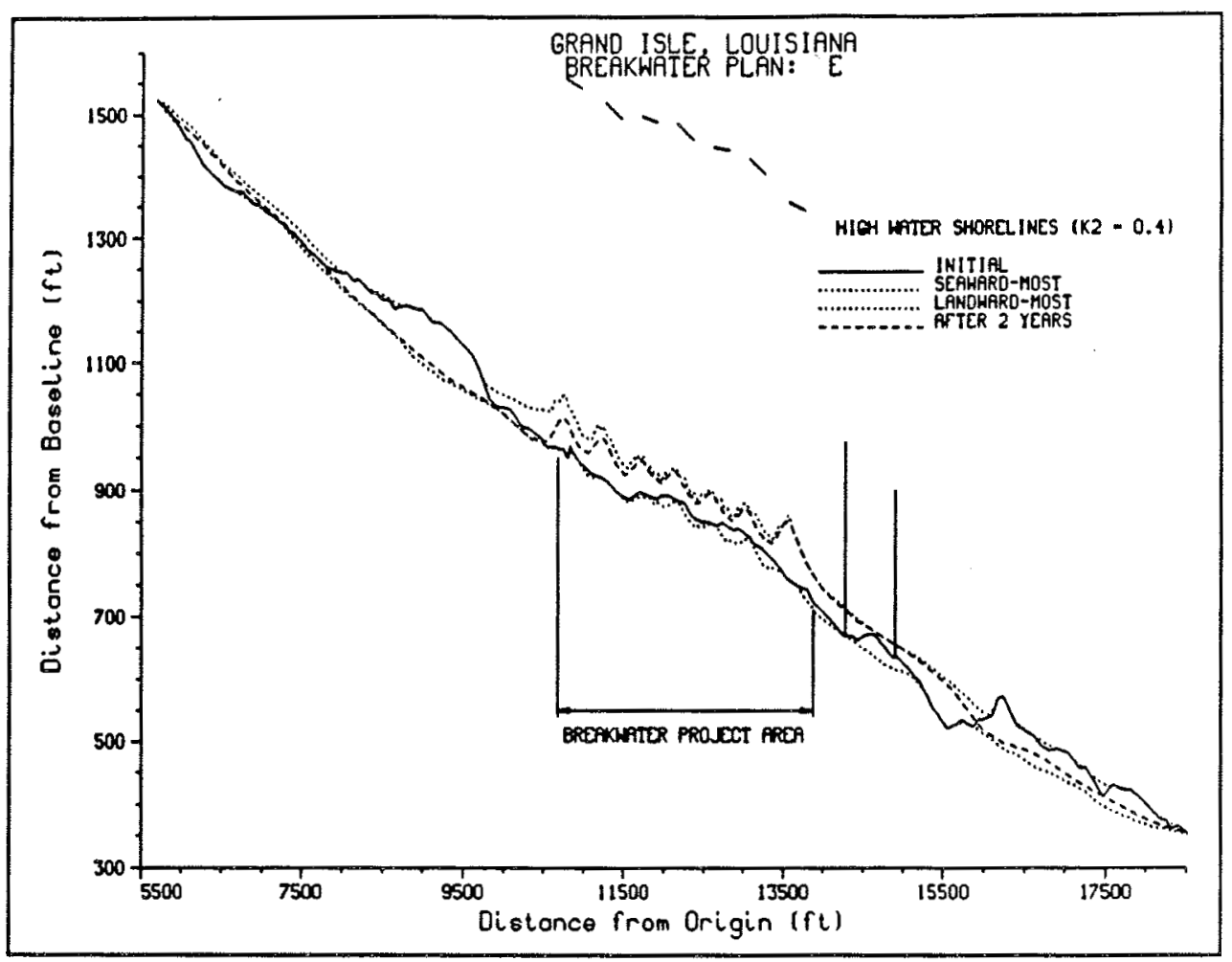

Figure 21. Breakwater design configuration E (2-year simulation)

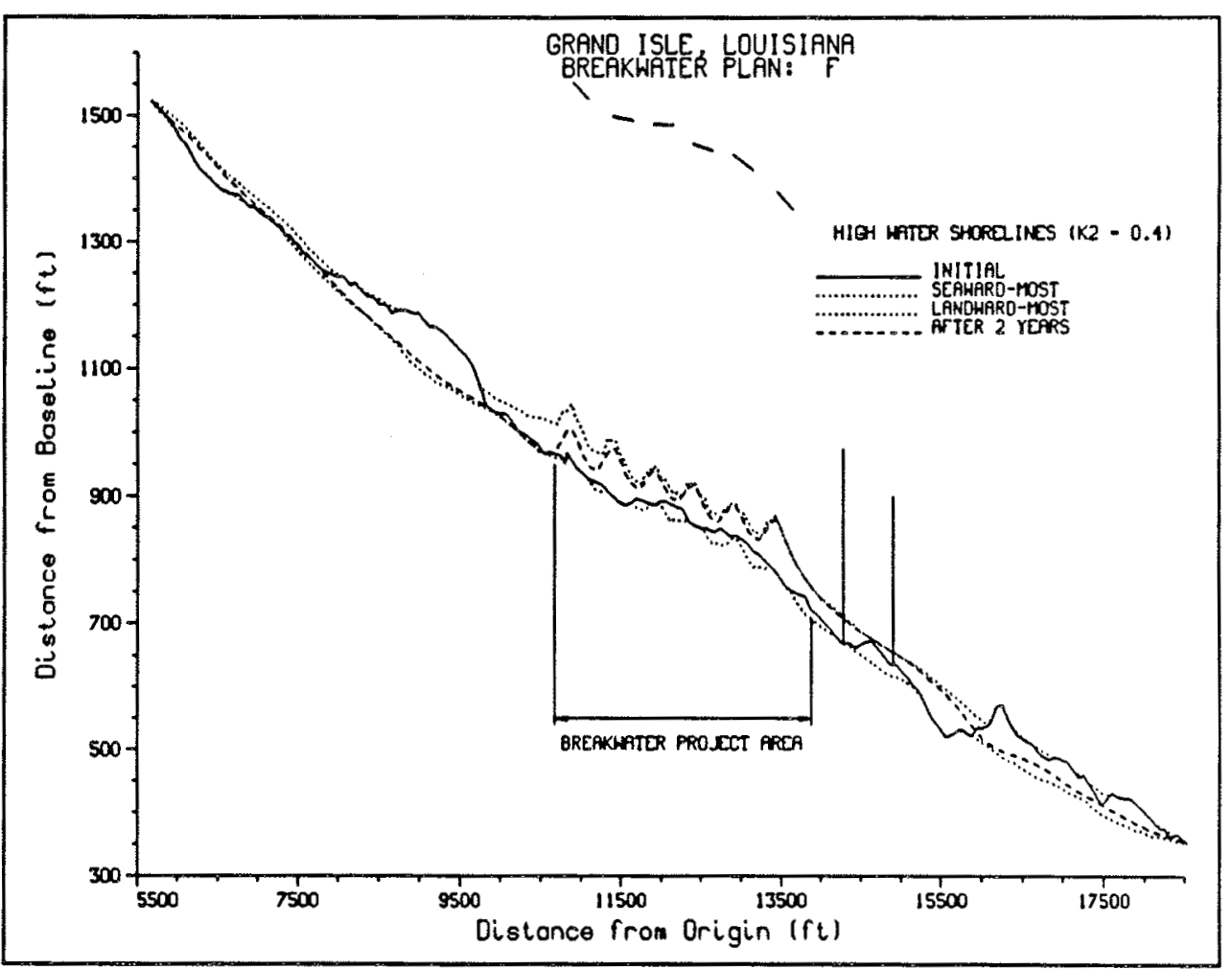

Figure 22. Breakwater design configuration $F$ (2-year simulation) 


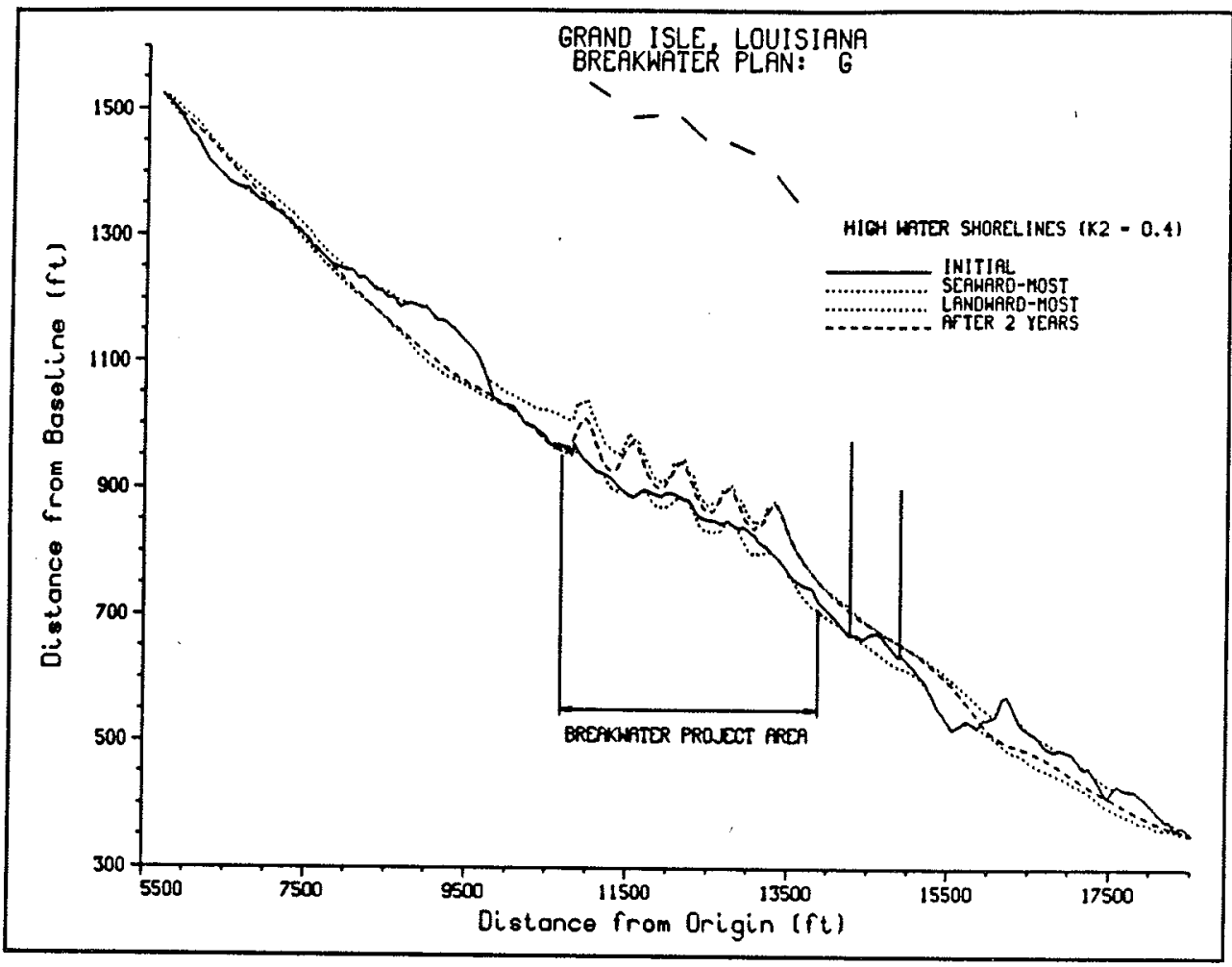

Figure 23. Breakwater design configuration G (2-year simulation)

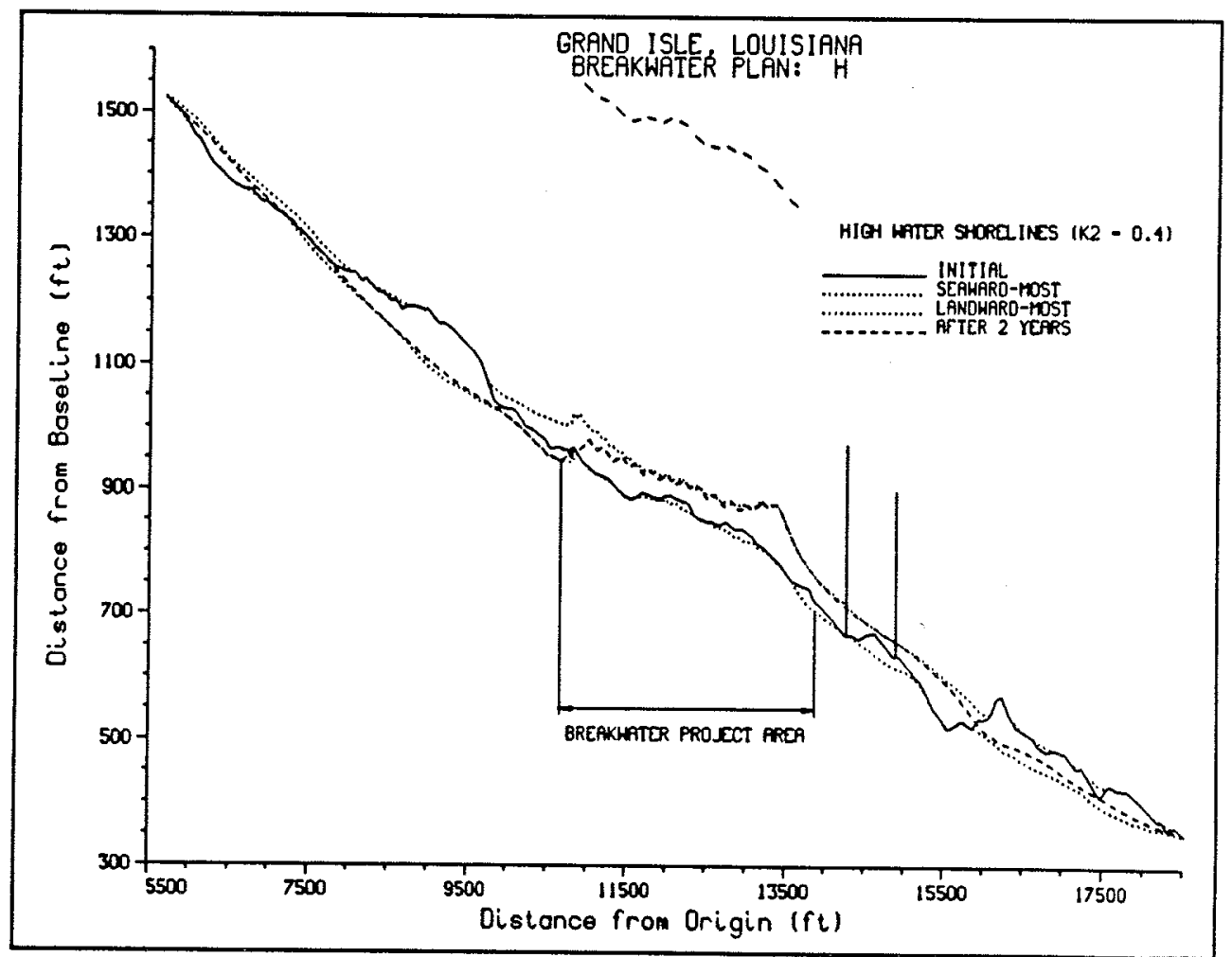

Figure 24. Breakwater design configuration $\mathrm{H}$ (2-year simulation) 


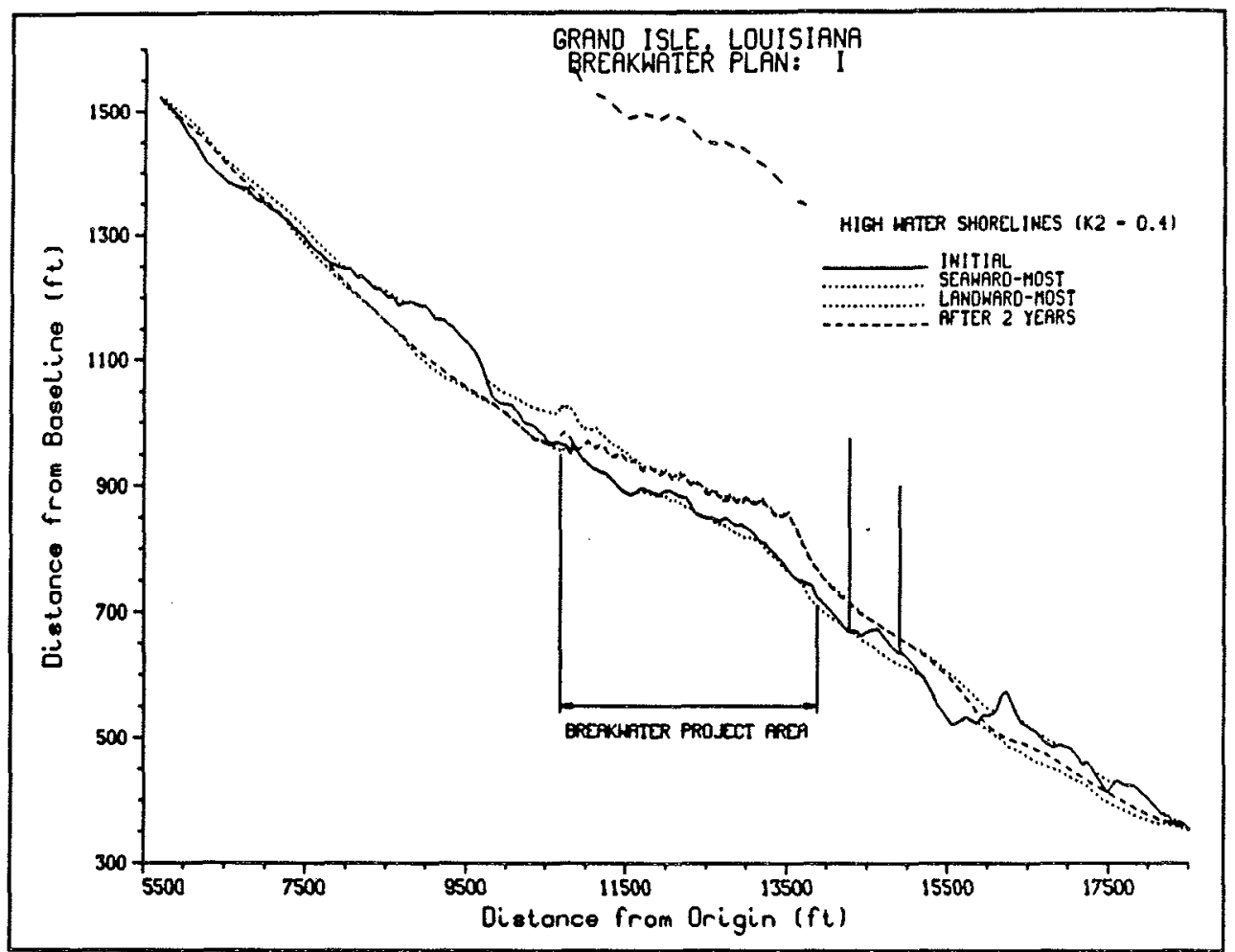

Figure 25. Breakwater design configuration I (2-year simulation)

reduce wave energy only locally and outside their area of influence normal wave activity and its capacity to move beach sediments remains unchanged. Likewise, if the breakwater system successfully traps sand and the shorelines behind them accrete, then the material that is trapped by the breakwaters is denied from some other part of the littoral system.

The initial goal was to select the breakwater configuration that provides protection within the project reach while minimizing expected downdrift impacts. Subsequent simulations were performed to quantify nourishment requirements for downdrift beaches. With these initial estimates of the influence of the proposed breakwater systems, and a basic understanding of the expected shoreline changes that will occur after the breakwaters are constructed, the project specific impacts were extracted and the proposed breakwater design configurations compared.

To effectively extract the project impacts, within the constraints of a numerical simulation approach, the predicted without-project shoreline changes are subtracted from the predicted with project shoreline changes. This calculation reveals the predicted shoreline change that occurred (due to the project) beyond estimated shoreline change for the without-project configuration (no breakwaters). Figures 26 and 27 illustrate this concept for proposed design configuration D. In Figure 26, the solid line and vectors represent the predicted shoreline change from the initial condition (August 


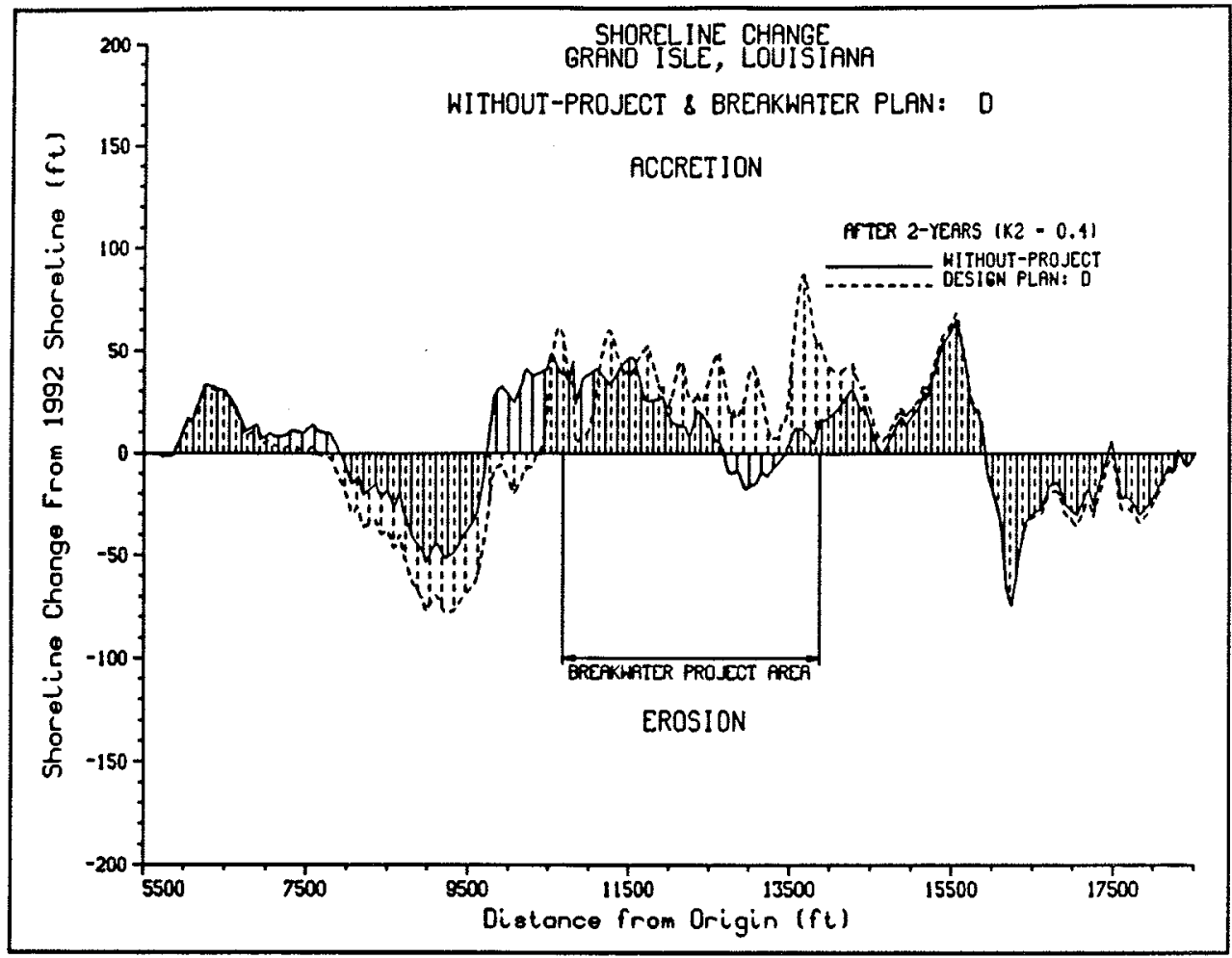

Figure 26. Predicted shoreline change for without-project and configuration D

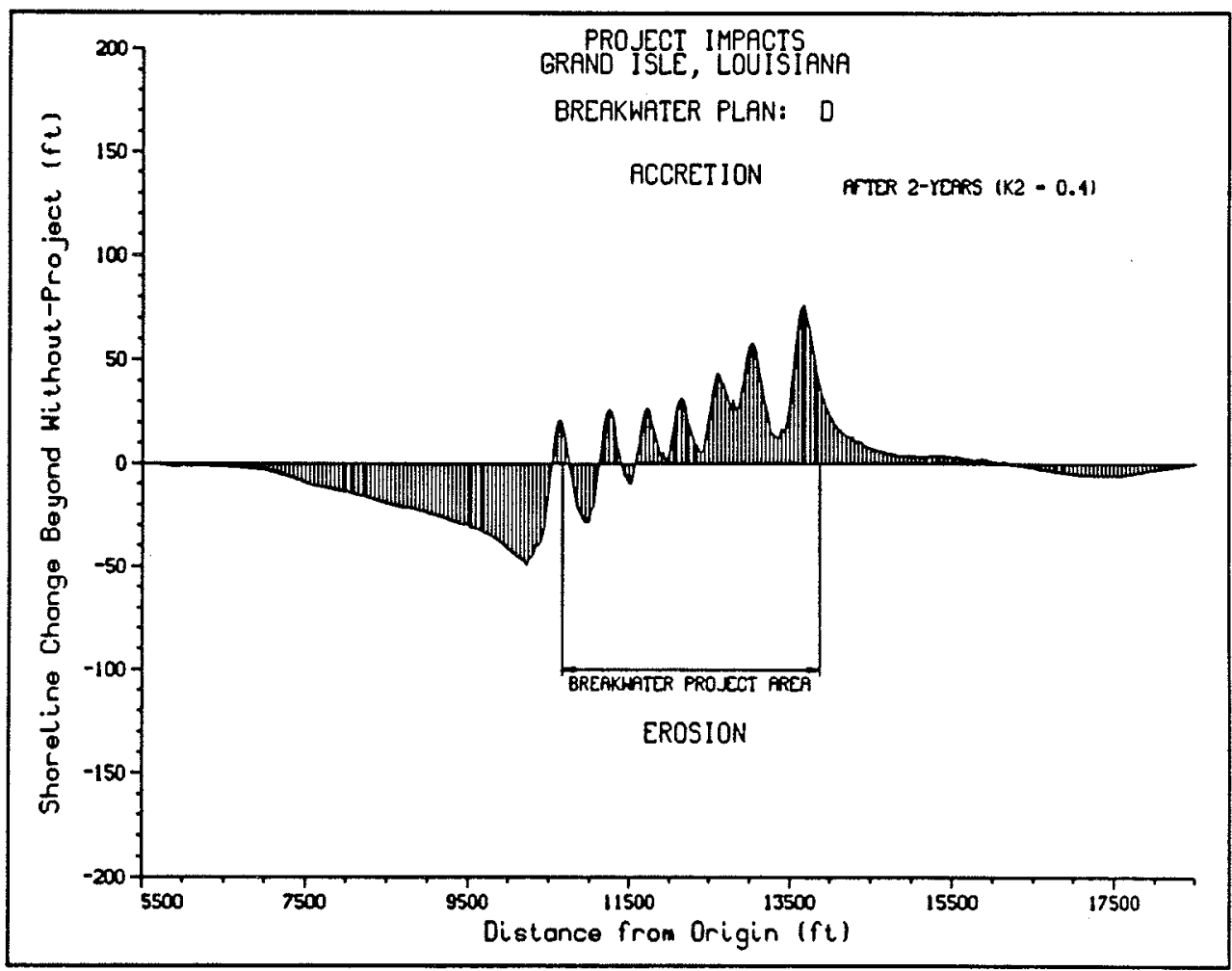

Figure 27. Project impacts, design configuration D 
1992) for the without-project and the dashed line and vectors represent the predicted shoreline change for design configuration $\mathrm{D}$. The plot shown in Figure 27 depicts the differences between the solid and dashed lines in Figure 26 , and represents shoreline change directly attributable to the project.

Negative impacts imply erosion induced by the project and positive impacts imply shoreline accretion resulting from the project.

To quantitatively inter-compare the proposed design configurations, project impact plots (as shown in Figure 27) were constructed for all of the 2-yearduration simulations. Additionally, the project impacts (shoreline change attributable to the project) were converted to volumetric beach change estimates by multiplying the shoreline change by the active profile height and the grid cell spacing. Table 6 summarizes the results of these calculations and provides a basis upon which the individual configurations can be quantitatively inter-compared. In Table 6, volumetric beach changes are shown for five areas; downdrift erosion (the area to the east of the breakwaters), gap erosion (the cumulative volumetric gap erosion west of the eastern-most accretive salient), salient accretion (the cumulative volumetric accretion within the salient), updrift erosion (the volumetric erosion west of the breakwaters, see Figure 27), and overall (the cumulative volumetric beach change across the model reach). Two values are listed in each of the table cells the first value is the volumetric change for the simulation in which $\mathrm{K}_{2}$ was assigned a value of 0.4 and the second value is for the simulation in which $K_{2}$ was assigned a value of 0.8 . It is noted that the overall volumetric beach change for each of the breakwater design configurations indicates net erosion ranging from about $3,000 \mathrm{yd}^{3}$ to in excess of $10,000 \mathrm{yd}^{3}$. This overall erosion was an unexpected

\begin{tabular}{|c|c|c|c|c|c|}
\hline \multicolumn{6}{|c|}{$\begin{array}{l}\text { Table } 6 \\
\text { Breakwater Project Impacts; Beach Volume Changes after } 2 \text { years } \\
\left.\text { (thousand } y d^{3}\right)^{*}\end{array}$} \\
\hline $\begin{array}{l}\text { Breakwater } \\
\text { Design } \\
\text { Configuration }\end{array}$ & $\begin{array}{l}\text { Downdrift } \\
\text { Erosion }\end{array}$ & $\begin{array}{l}\text { Gap } \\
\text { Erosion }\end{array}$ & $\begin{array}{l}\text { Salient } \\
\text { Accretion }\end{array}$ & $\begin{array}{l}\text { Updrift } \\
\text { Erosion }\end{array}$ & Overall \\
\hline A & $-80.9 /-93.5$ & $-0.1 / 0.0$ & $82.4 / 105.0$ & $-5.5 /-21.3$ & $-4.1 /-9.8$ \\
\hline B & $-73.6 /-83.8$ & $-0.9 / 0.0$ & $75.8 / 96.2$ & $-5.3 /-21.7$ & $-4.0 /-9.3$ \\
\hline c & $-66: 8 /-75.6$ & $-1.4 / 0.0$ & $70.2 / 90.4$ & $-5.5 /-23.5$ & $-3.5 /-8.7$ \\
\hline$D$ & $-60.5 /-68.6$ & $-5.9 /-3.0$ & $67.6 / 87.0$ & $-6.0 /-26.5$ & $-4.8 /-11.1$ \\
\hline$E$ & $-64.1 /-71.6$ & $-2.8 /-0.2$ & $69.2 / 88.0$ & $-5.7 /-24.7$ & $-3.4 /-8.5$ \\
\hline $\mathbf{F}$ & $-63.0 /-69.3$ & $-4.0 /-1.1$ & $68.7 / 85.0$ & $-5.7 /-24.0$ & $-4.0 /-9.4$ \\
\hline G & $-61.71-68.4$ & $-5.2 /-2.4$ & $68.1 / 84.7$ & $-5.7 /-24.1$ & $-4.5 /-10.2$ \\
\hline $\mathrm{H}$ & $-82.8 /-99.3$ & $0.0 / 0.0$ & $83.8 / 106.7$ & $-4.8 /-16.0$ & $-3.8 /-8.6$ \\
\hline 1 & -80.81 & $0.01=$ & $82.4 /=$ & $-4.9 /=$ & $-3.3 /$ \\
\hline
\end{tabular}


result, but was later found to be temporary. For longer duration simulations, the overall change will be shown to switch to one of accretion. Examining Table 6 it is seen that breakwater design configuration D results in the minimum amount of downdrift beach erosion while still accumulating in excess of $67,000 \mathrm{yd}^{3}$ of beach within the salient behind the breakwaters. Breakwater design configuration $\mathrm{D}$ was determined to be the most favorable alternative of the initial configurations proposed. However, it was acknowledged that the differences (both in the structural layout and in their performance) between design configurations $\mathrm{C}, \mathrm{D}$, and $\mathrm{E}$ were very slight. Design configurations $F$ and $G$ also produced similar volumetric changes but, from the perspective of the width of beach protected by the breakwater system, design configurations $\mathrm{C}, \mathrm{D}$, and $\mathrm{E}$ were selected as more favorable because they provide protection for 250 to $600 \mathrm{ft}$ more shoreline. Design configurations A, B, H, and I were dismissed because of the magnitude of the predicted downdrift erosion.

At this point of the study CERC and LMN personnel developed three additional design configurations based on the preceding analysis of the initial design configurations. Table 7 summarizes the new breakwater design configurations hereafter referred to as configurations D1, D2 and D3. Design configuration D1 was developed based on the observation that the most favorable result was obtained from the initial configuration that spanned the longest distance alongshore. Design configuration D2 (the only asymmetric design configuration evaluated) was developed as a variant of configurations $\mathrm{C}, \mathrm{D}$, and $\mathrm{E}$. Whereas, design configuration D3 is primarily a variant of configuration $\mathrm{E}$.

\begin{tabular}{|c|c|c|c|c|c|c|c|}
\hline \multicolumn{8}{|c|}{$\begin{array}{l}\text { Table } 7 \\
\text { Refined Breakwater Configurations* }\end{array}$} \\
\hline \multirow{2}{*}{$\begin{array}{l}\text { Breakwater } \\
\text { Design } \\
\text { Configuration }\end{array}$} & \multirow{2}{*}{$\begin{array}{l}\text { Number } \\
\text { of } \\
\text { Segments }\end{array}$} & \multirow{2}{*}{$\begin{array}{l}\text { Segment } \\
\text { Length (ft) } \\
\text { Lo }\end{array}$} & \multicolumn{5}{|c|}{ Gap Spacing $(f t)^{* *}$} \\
\hline & & & LgE1 & $\operatorname{LgE2}$ & $\operatorname{Lg}$ & LgW2 & LgW1 \\
\hline D1 & 7 & $200(7)$ & $\begin{array}{l}350 \\
\text { (1) }\end{array}$ & - & $\begin{array}{l}300 \\
\text { (4) }\end{array}$ & - & $\begin{array}{l}350 \\
\text { (1) }\end{array}$ \\
\hline D2 & 7 & $200(7)$ & $\begin{array}{l}350 \\
\text { (1) } \\
\end{array}$ & $\begin{array}{l}300 \\
\text { (1) }\end{array}$ & $\begin{array}{l}250 \\
(2) \\
\end{array}$ & $\begin{array}{l}250 \\
(1) \\
\end{array}$ & $\begin{array}{l}250 \\
(1) \\
\end{array}$ \\
\hline D3 & 7 & $200(7)$ & $\begin{array}{l}300 \\
\text { (1) }\end{array}$ & $\begin{array}{l}300 \\
\text { (1) }\end{array}$ & $\begin{array}{l}250 \\
(2) \\
\end{array}$ & $\begin{array}{l}300 \\
\text { (1) }\end{array}$ & $\begin{array}{l}300 \\
\text { (1) }\end{array}$ \\
\hline \multicolumn{8}{|c|}{$\begin{array}{l}\text { *All configurations represent structures in } 6 \mathrm{ft} \text { of water, oriented parallel to trend of } \\
\text { shoreline, located approximately } 600 \mathrm{ft} \text { offshore from the original shoreline, and centered } \\
\text { approximately } 2,000 \mathrm{ft} \text { east of the Mayor of Grand Isle's breakwater project. } \\
\text { * If all gap distances are equal, only } L_{0} \text { is given; if } L_{p \in 2}=L_{0}=L_{0 w 2} \text {, these distances are } \\
\text { represented by } L_{g} \text {; the number of each gap distance is given in parentheses. }\end{array}$} \\
\hline
\end{tabular}




\section{4-year-duration simulations}

The next set of project evaluation simulations performed was for a simulation duration of 4 years and only design alternatives D, D1, D2, and D3 were modeled. The purpose of these simulations was first to determine if the shoreline response to the breakwaters had equilibrated within the 2-yearduration simulations and second to evaluate the performance of design configurations D1, D2, and D3 relative to design configuration D and the without-project alternative. The results of these simulations are provided in Figures $28-36$. Figure 28 shows the results for the 4-year without-project simulation which appears almost identical to the response observed for the 2-year-duration simulation shown in Figure 16. This indicates that for the without-project condition, predicted shoreline change, as driven by wave induced sediment transport processes, equilibrates within the first 2 years and remains relatively stable thereafter using the representative wave conditions employed herein.

Model results for the breakwater design configurations are presented in two plots for each design simulated. The first plot shows the initial shoreline position (solid line), the seaward-most and landward-most shoreline positions (dotted lines), and finally the calculated shoreline position at the end of the 4year simulation project. The second plot shows the project impacts for the design configuration. It can be seen by comparing Figures 29 and 30 with

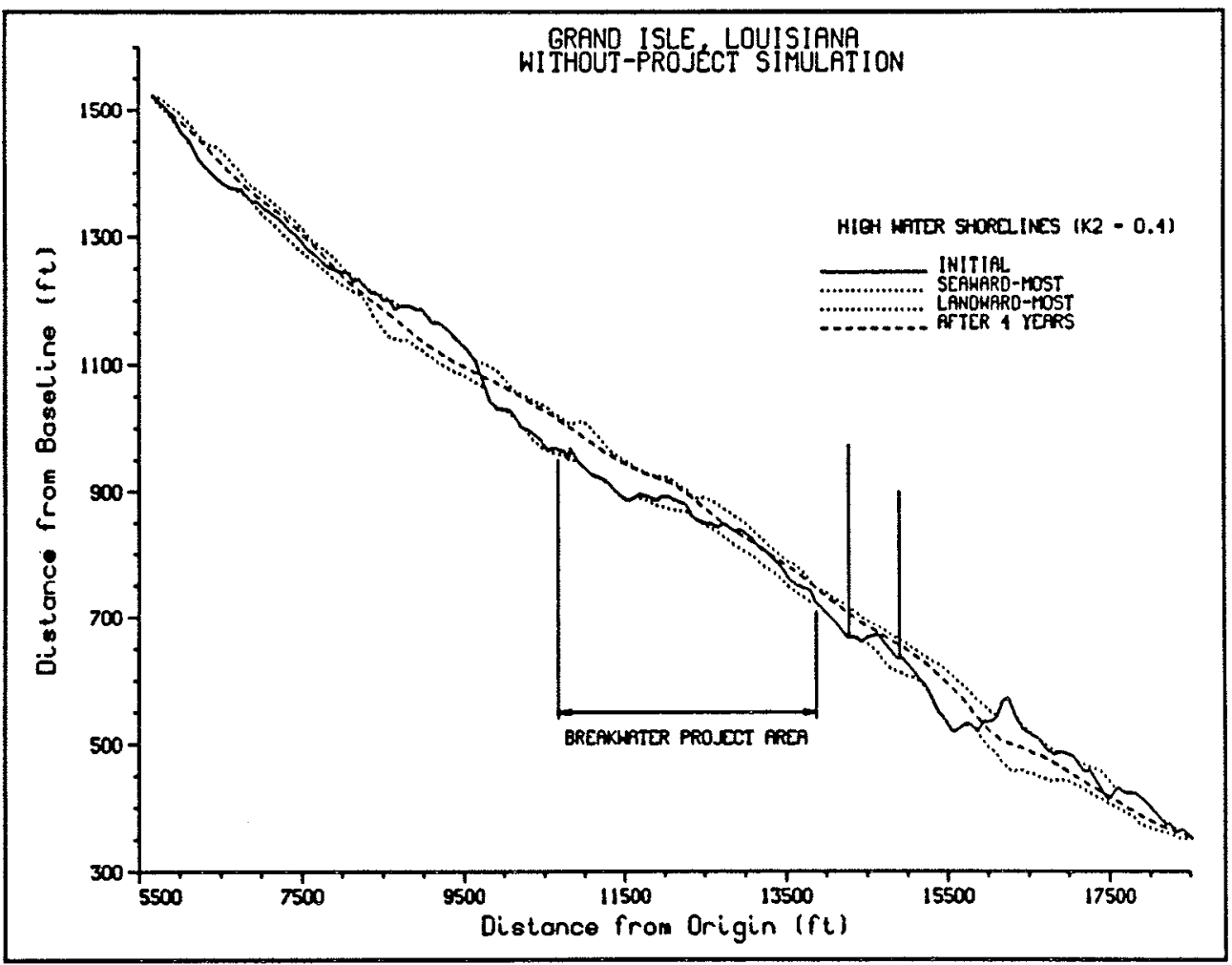

Figure 28. Without-project shoreline change forecast (4-year simulation) 


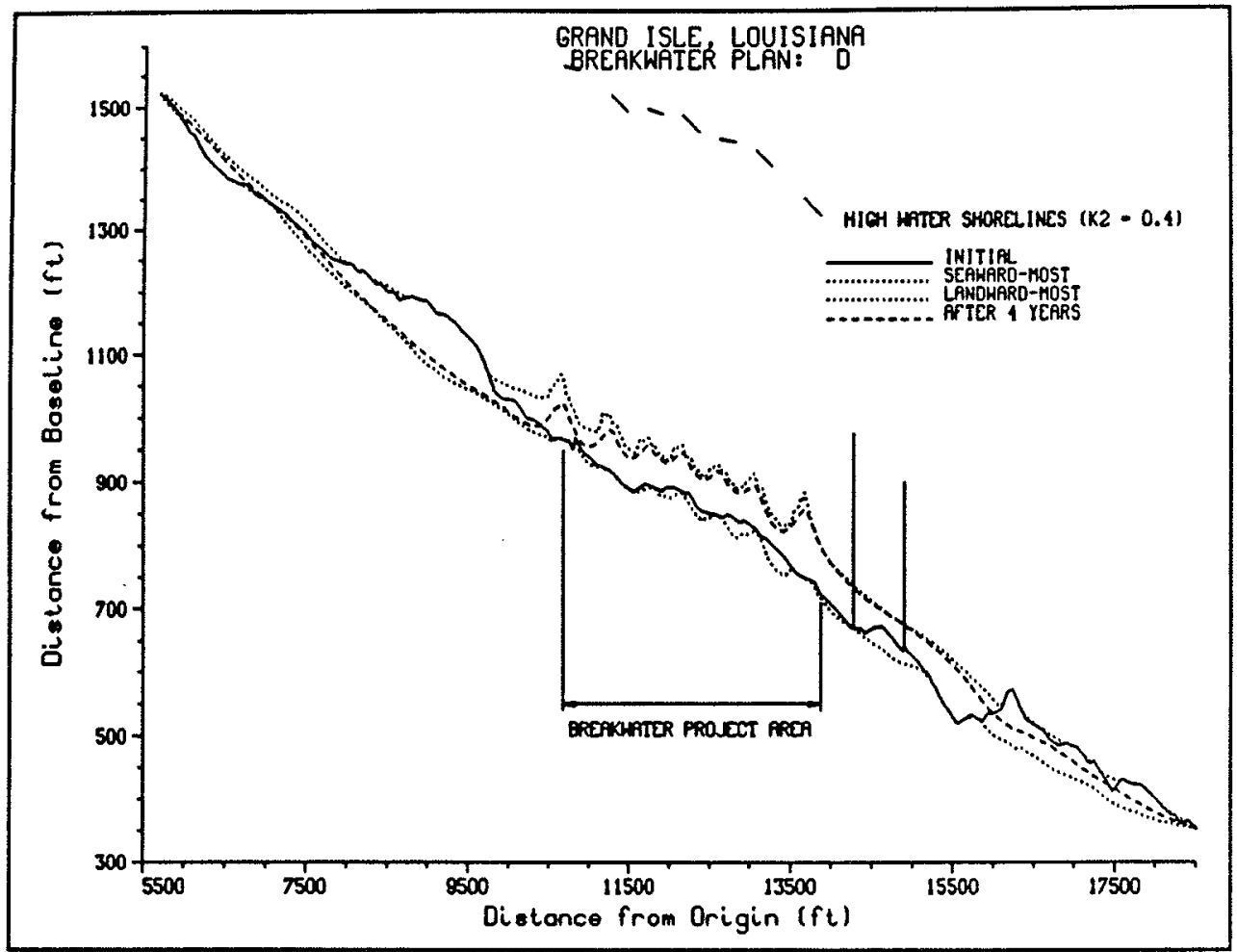

Figure 29. Breakwater design configuration D (4-year simulation)

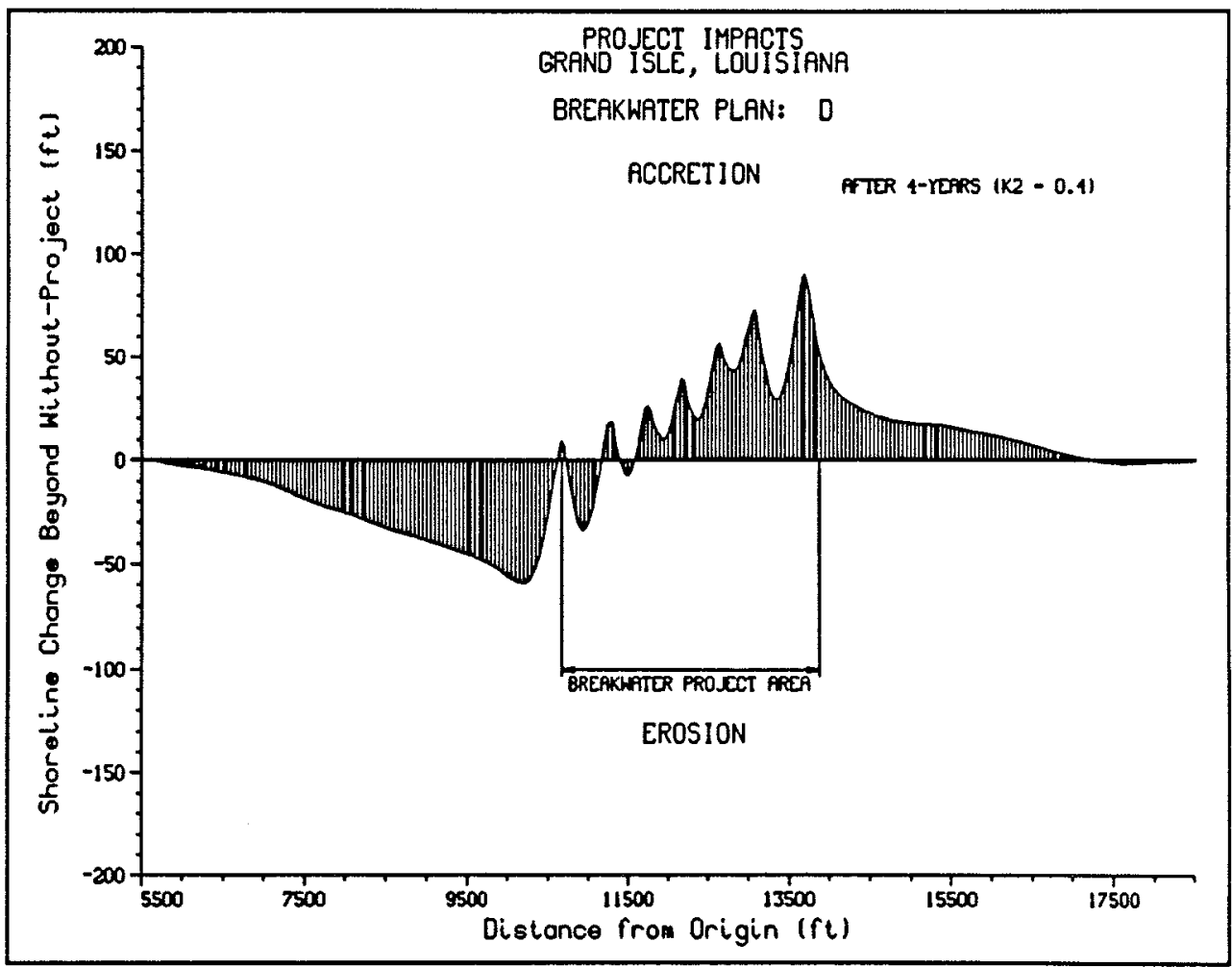

Figure 30. Project impacts, design configuration D (4-year simulation) 


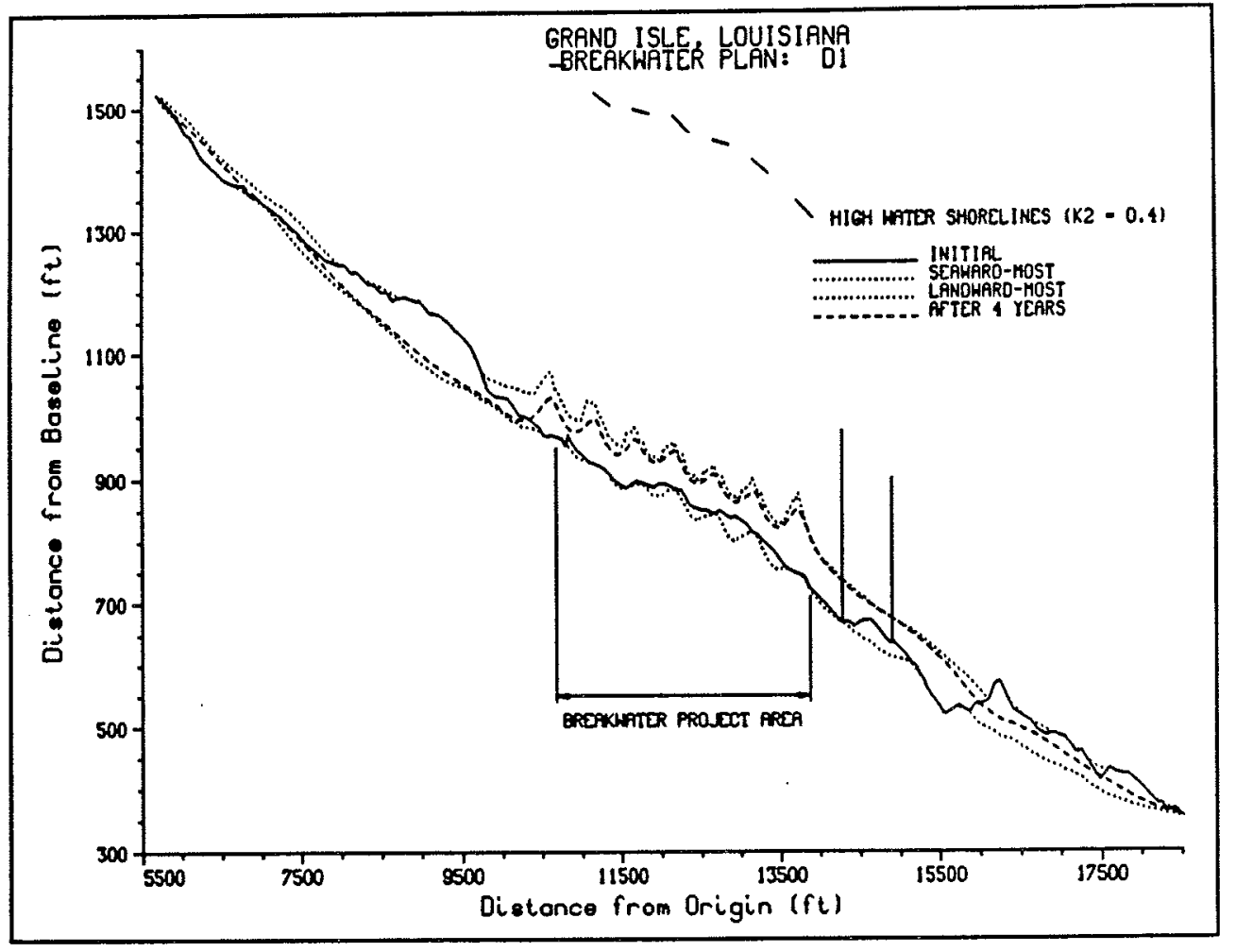

Figure 31. Breakwater design configuration D1 (4-year simulation)

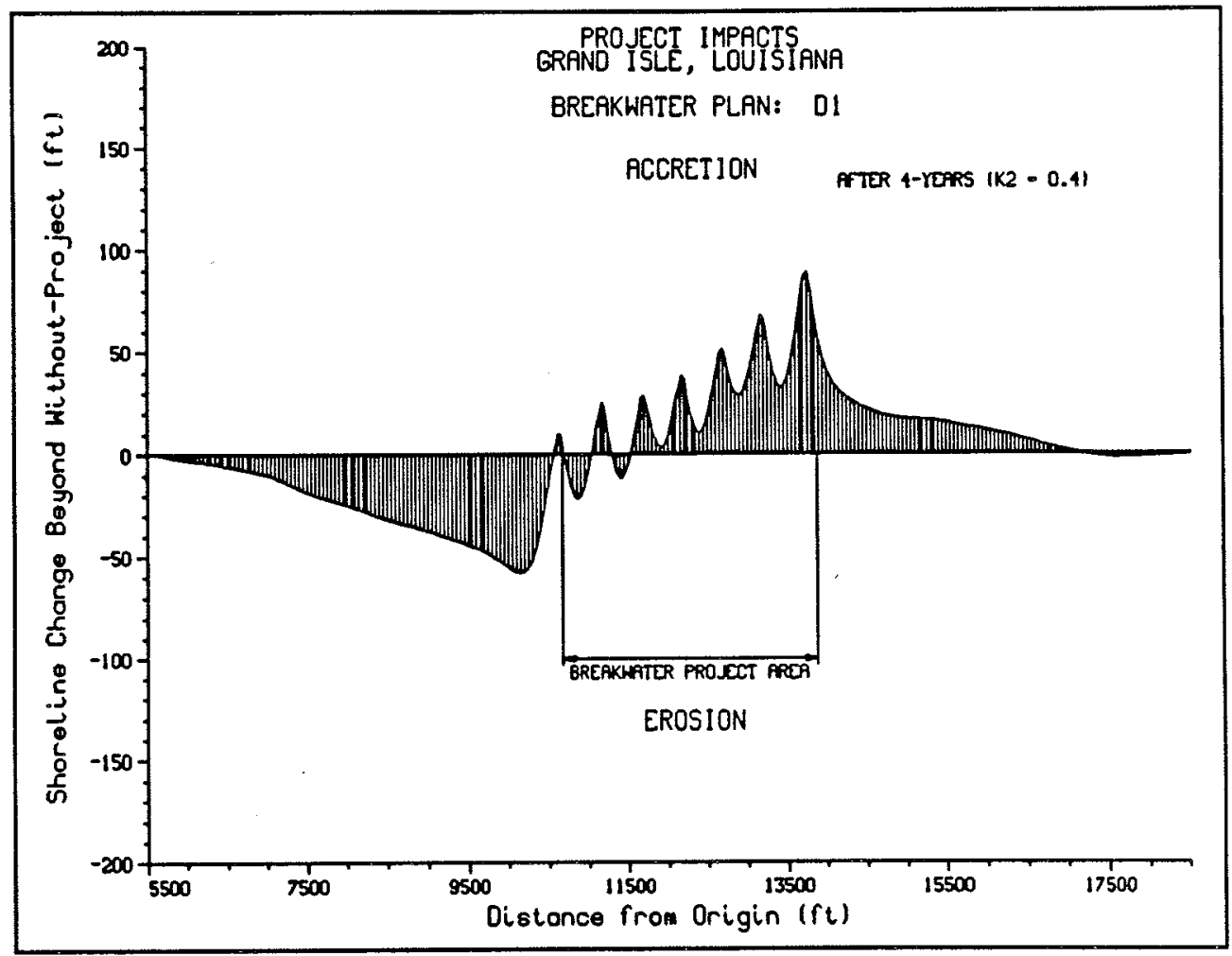

Figure 32. Project impacts, design configuration D1 (4-year simulation) 


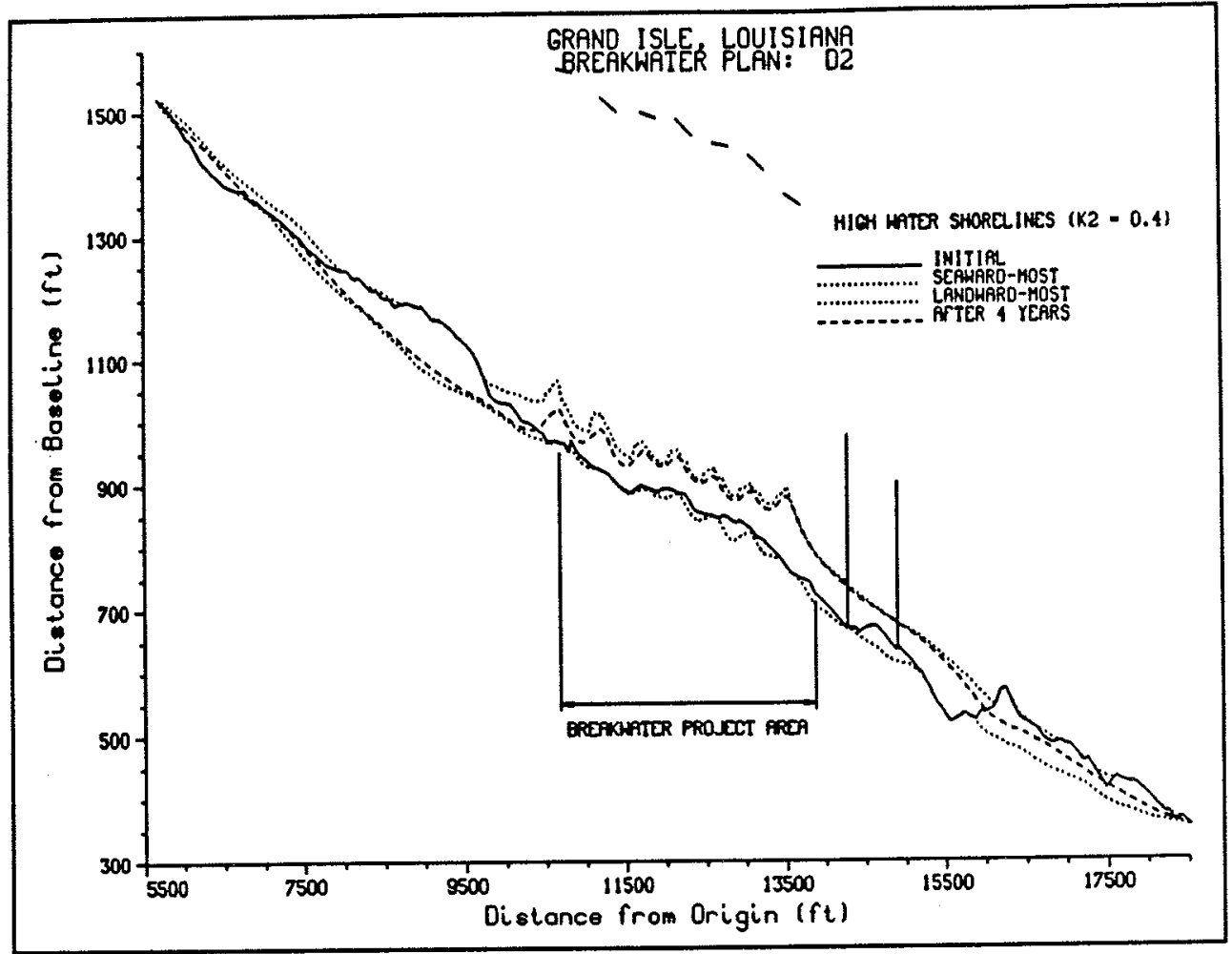

Figure 33. Breakwater design configuration D2 (4-year simulation)

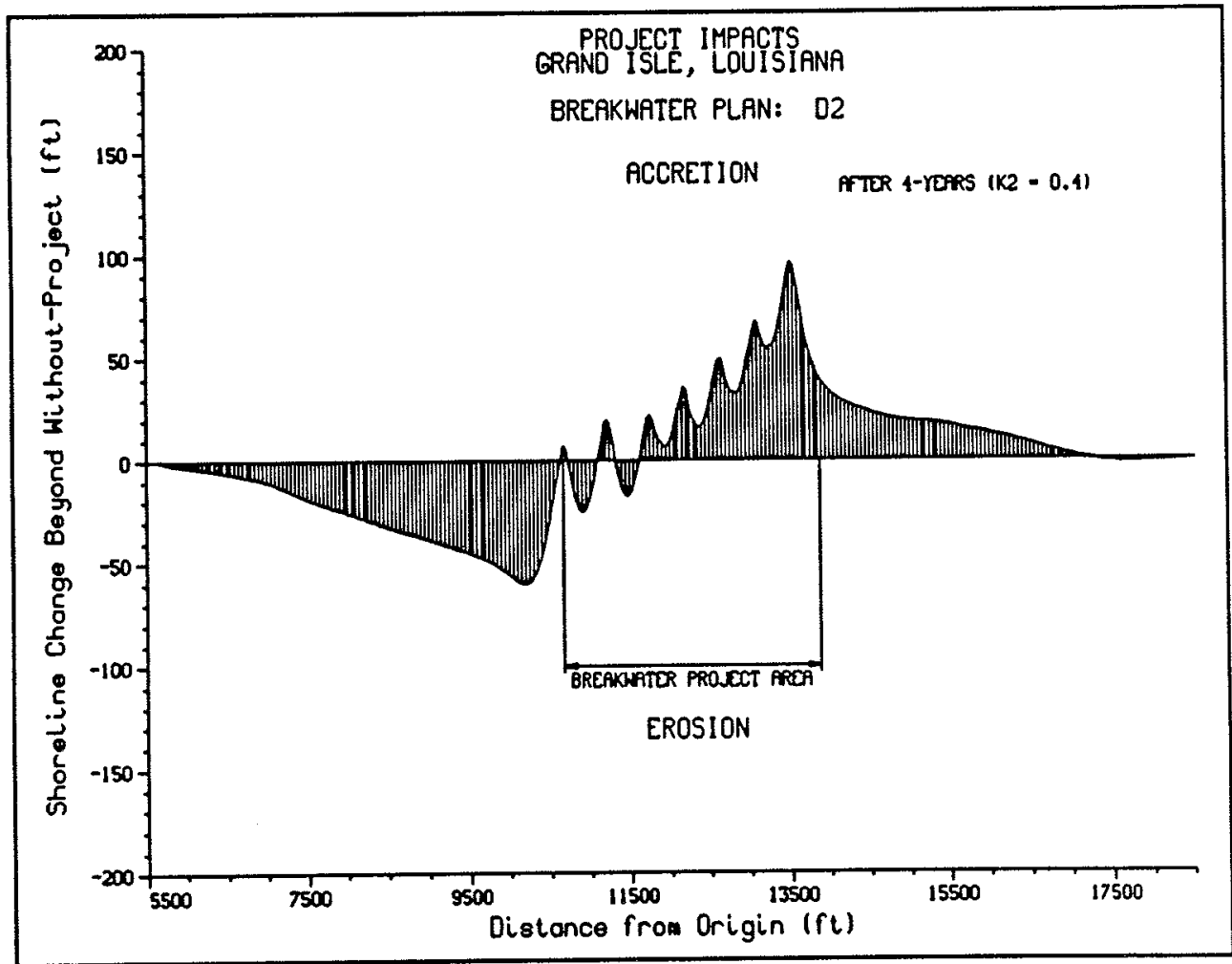

Figure 34. Project impacts, design configuration D2 (4-year simulation) 


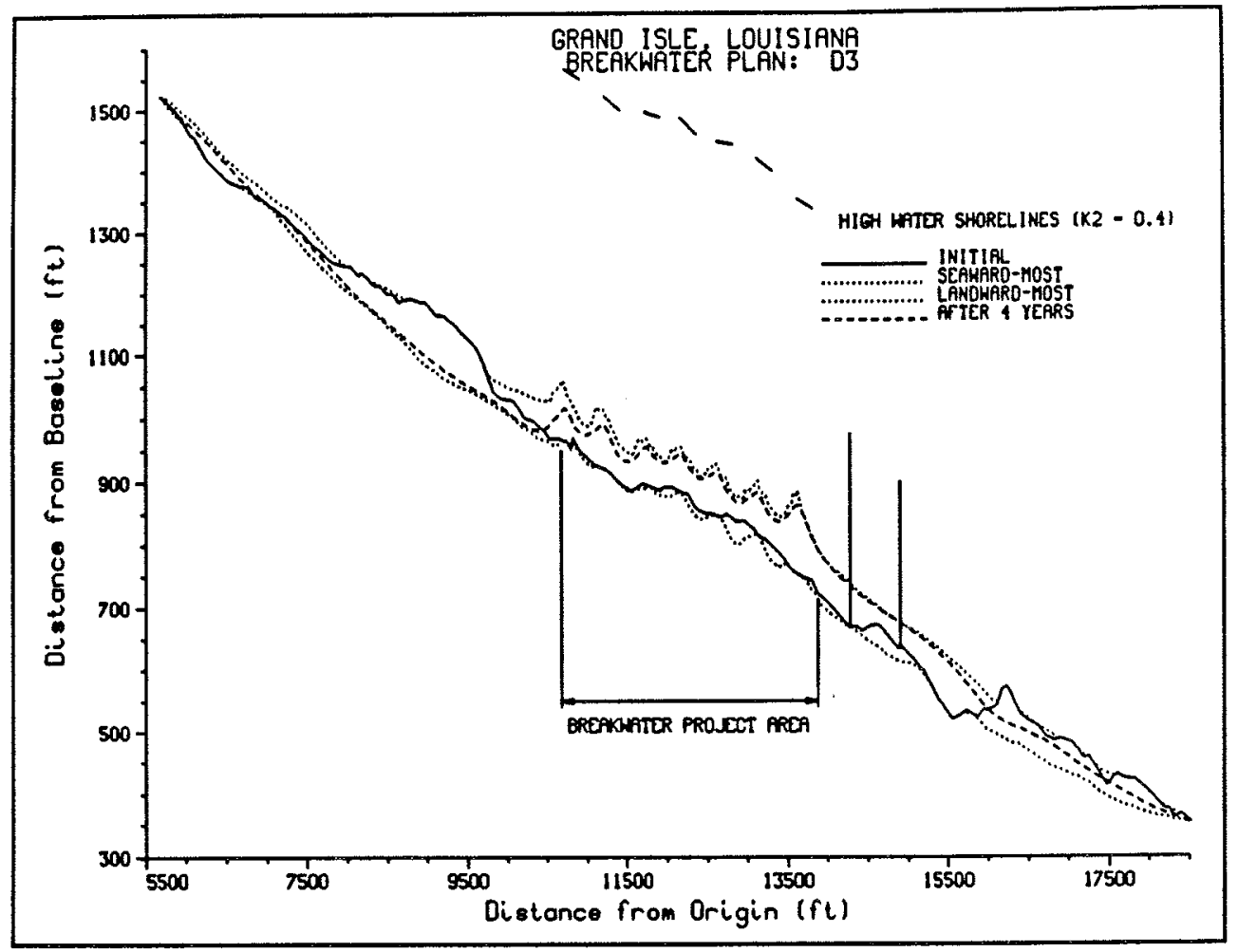

Figure 35. Breakwater design configuration D3 (4-year simulation)

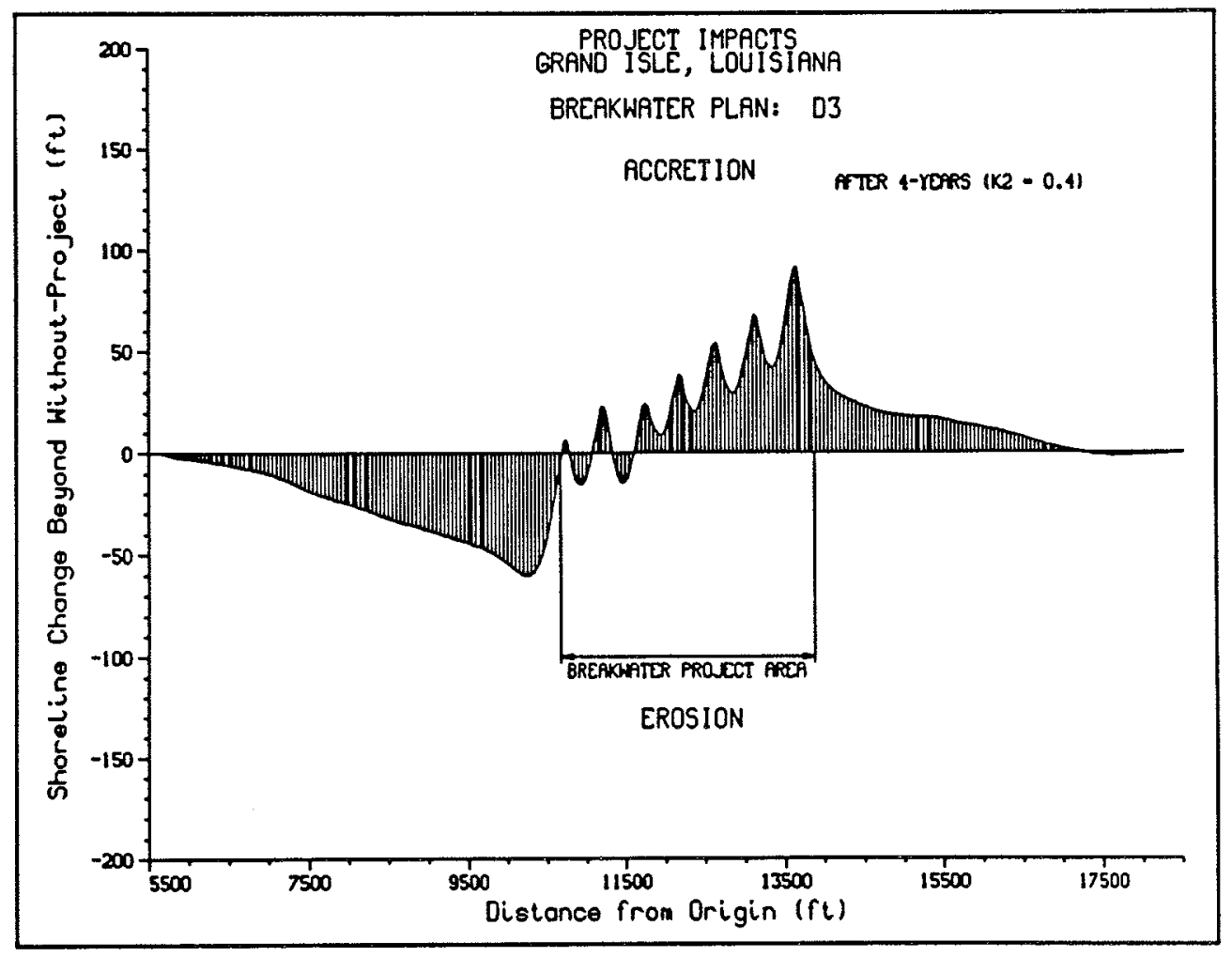

Figure 36. Project impacts, design configuration D3 (4-year simulation) 
Figures 20 and 27 that the shoreline continues to respond to the system of breakwaters, evolving beyond the shoreline condition observed from the 2 -year-duration simulation. This was also observed by calculating the volumetric beach change for each of the design configurations. Table 8 summarizes the results of the volumetric calculations for the 4-year-duration simulations. As seen in Table 8, downdrift erosion for design configuration D is approximately 52 percent greater than volumetric erosion estimated in the 2-year-duration simulation, indicating equilibrium conditions were not achieved within the 2-year simulation. Likewise, volumetric accretion within the salient increased approximately 53 percent between the 2- and 4-yearduration simulations. Breakwater design configuration D1 is estimated to produce the least amount of downdrift erosion while providing protection (through shoreline accretion) for an alongshore distance of approximately $6,000 \mathrm{ft}$ behind and updrift of the breakwater system. The results for breakwater design configurations D2 and D3 do not indicate a performance improvement over design configuration $\mathrm{D}$, rather resulting in slightly increased downdrift beach erosion. It is noted that shoreline accretion is predicted to extend approximately $3,000 \mathrm{ft}$ updrift of the western-most breakwater tip indicating that when constructed, the system of breakwaters should be sited to some extent downdrift of the region that needs to be protected. In summary, the 4-year-duration simulations showed that breakwater design configuration D1 is the most effective breakwater design but, as evidenced by comparison to the 2-year-duration simulations, the attainment of equilibrium conditions had not been realized (the shoreline continued to evolve beyond the predicted shoreline response in the 2-yearduration simulation). Results of the 4-year simulations indicated that longer duration simulations were required to estimate equilibrium conditions.

\begin{tabular}{|c|c|c|c|c|c|}
\hline \multicolumn{6}{|c|}{$\begin{array}{l}\text { Table } 8 \\
\text { Breakwater Project Impacts; Beach Volume Changes after } 4 \text { years } \\
\left.\text { (thousand } \mathrm{yd}^{3}\right)^{*}\end{array}$} \\
\hline $\begin{array}{l}\text { Breakwater } \\
\text { Design } \\
\text { Configuration }\end{array}$ & $\begin{array}{l}\text { Downdrift } \\
\text { Erosion }\end{array}$ & $\begin{array}{l}\text { Gap } \\
\text { Erosion }\end{array}$ & $\begin{array}{l}\text { Salient } \\
\text { Accretion }\end{array}$ & $\begin{array}{l}\text { Updrift } \\
\text { Erosion }\end{array}$ & Overall \\
\hline$D$ & $-96.8 /-99.4$ & $-7.6 /-3.1$ & $111.8 / 124.1$ & $-0.8 /-9.7$ & $6.6 / 11.9$ \\
\hline D1 & $-92.4 /-97.2$ & $-4.8 /-0.4$ & $104.6 / 119.0$ & $-0.9 /-9.8$ & $6.1 / 11.6$ \\
\hline$D 2$ & $-97.4 /-102.3$ & $-6.9 / 1.4$ & $111.4 / 123.4$ & $-0.7 /-8.7$ & $6.4 / 11.0$ \\
\hline D3 & $-99.3 /-104.4$ & $-4.2 /-0.2$ & $110.5 / 125.9$ & $-0.8 /-9.3$ & $6.2 / 12.0$ \\
\hline
\end{tabular}

\section{6-year-duration simulations}

The next set of project evaluation simulations was performed to estimate an equilibrium shoreline planform response to the breakwaters. A series of 
6-year-duration model simulations was performed for this purpose.

Breakwater design configurations D, D1, and for comparison purposes, the without-project condition were simulated in these model runs.

Table 9 summarizes the results of the volumetric beach change calculations for these simulations. Note that the downdrift volumetric erosion increased less than 1 percent over the 4-year-duration simulation for design configuration $\mathrm{D}$ and actually decreased about 1 percent for design configuration D1. The volumetric beach accretion within the salient increased approximately 18 and 17 percent for design configurations D and D1, respectively. These relatively minor changes in the calculated volumetric beach change between the 4- and 6-year-duration simulations indicate that equilibrium conditions had been attained. The 6-year-duration simulation results suggest that the salient area may continue to increase slowly and downdrift erosion may in fact slowly diminish over the long-term.

\begin{tabular}{|c|c|c|c|c|c|}
\hline \multicolumn{6}{|c|}{$\begin{array}{l}\text { Table } 9 \\
\text { Breakwater Project Impacts; Beach Volume Changes after } 6 \text { years } \\
\left.\text { (thousand } \mathrm{yd}^{3}\right)^{*}\end{array}$} \\
\hline $\begin{array}{l}\text { Breakwater } \\
\text { Design } \\
\text { Configuration }\end{array}$ & $\begin{array}{l}\text { Downdrift } \\
\text { Erosion }\end{array}$ & $\begin{array}{l}\text { Gap } \\
\text { Erosion }\end{array}$ & $\begin{array}{l}\text { Salient } \\
\text { Accretion }\end{array}$ & $\begin{array}{l}\text { Updrift } \\
\text { Erosion }\end{array}$ & Overall \\
\hline$D$ & $-103.7 / 93.9$ & $-8.2 /-1.9$ & $135.6 / 142.2$ & $0.0 /-1.9$ & $23.7 / 44.5$ \\
\hline D1 & $-97.9 /-89.7$ & $-4.9 / 0.0$ & $125.8 / 135.2$ & $0.01-1.8$ & $23.0 / 43.7$ \\
\hline
\end{tabular}

Figures 37 through 41 show the calculated shoreline positions and project impacts for the 6-year-duration simulations. Figure 37 presents the calculated shoreline position after 6 years, and the seaward- and landward-most shoreline positions for the without-project simulation. Figures 38 and 40 show the same shorelines for design configurations D and D1. Figures 39 and 41 show project impacts on shoreline change at the end of years 1 through 6 for design configurations D and D1. In Figures 39 and 41, it is seen that the predicted rate of shoreline change after three years decreases dramatically and project impacts remain relatively constant after this period indicating that equilibrium conditions have been attained.

Maximum shoreline changes as influenced by the breakwaters can be examined by plotting the difference between the seaward-most (and landwardmost) shoreline positions for the without-project and the seaward-most (and landward-most) shoreline positions for design configuration D1, as shown in Figure 42. Maximum shoreline erosion begins about $500 \mathrm{ft}$ east of the breakwater project, extends for a distance of approximately $1,500 \mathrm{ft}$, and has a magnitude of just less than $40 \mathrm{ft}$. Maximum shoreline accretion is observed behind the western breakwater and has a magnitude of just less that $120 \mathrm{ft}$. 


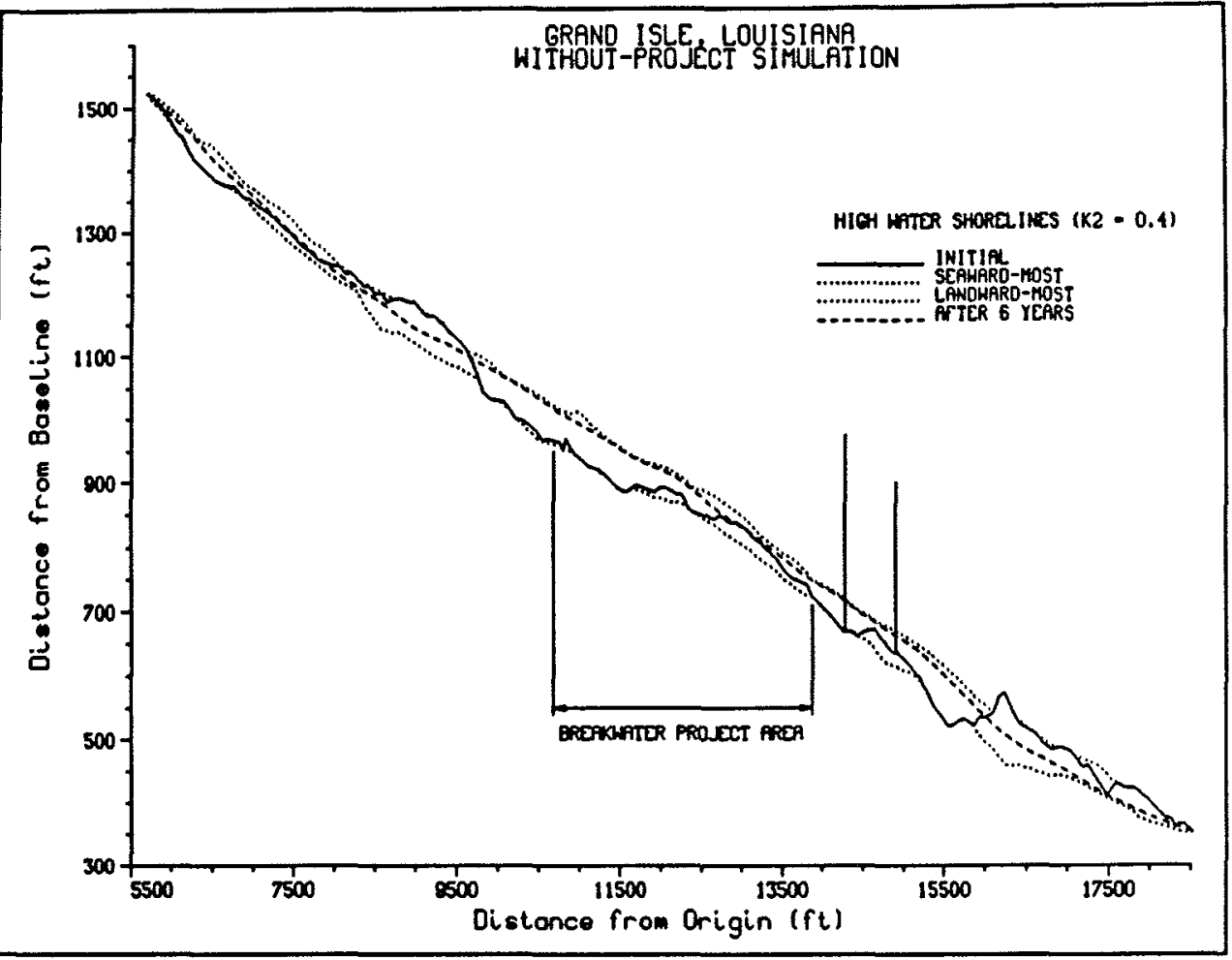

Figure 37. Without-project shoreline change forecast (6-year simulation)

The influence of the proposed system of breakwaters on littoral processes is further examined by comparing the calculated average annual longshore sand transport rates for the without-project simulation with those for breakwater design configuration D1. These plots are provided in Figures 43 and 44 . Through comparison of Figures 43 and 44 it is seen that the breakwaters serve to reduce left-directed, right-directed, and gross longshore sand transport rates dramatically in the vicinity of the breakwater project. Because the breakwaters block and diffract a significant portion of the incoming wave energy, the total wave energy that is finally expended on the beach behind the breakwaters is reduced. The average net longshore sand transport, on the other hand, being a derived quantity (the difference between the left- and right-directed sand transport), decreases more gradually. The net longshore sand transport rate for design configuration D1 begins to decrease (as compared to the without-project simulation) approximately $1,500 \mathrm{ft}$ west of the western-most breakwater. The minimum net longshore sand transport rate occurs approximately behind the eastern most breakwater. From this location eastward, the net longshore sand transport rate increases and approaches the net longshore sand transport rate estimated for the without-project condition.

\section{Beach nourishment simulations}

The next and final set of model simulations was performed to assess the effectiveness of implementing a beach nourishment program downdrift of the proposed breakwater project to limit any deleterious effects of the 


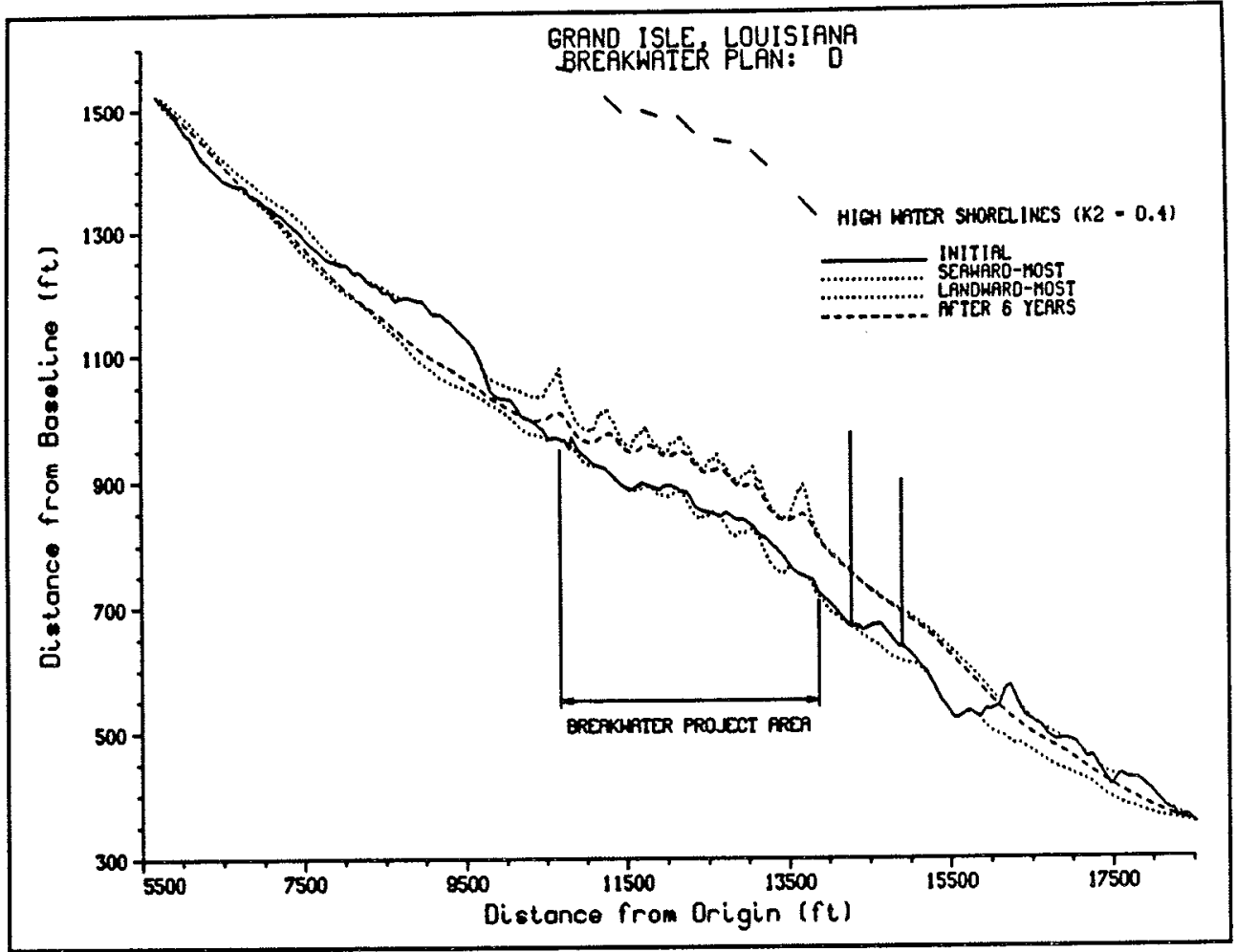

Figure 38. Breakwater design configuration D (6-year simulation)

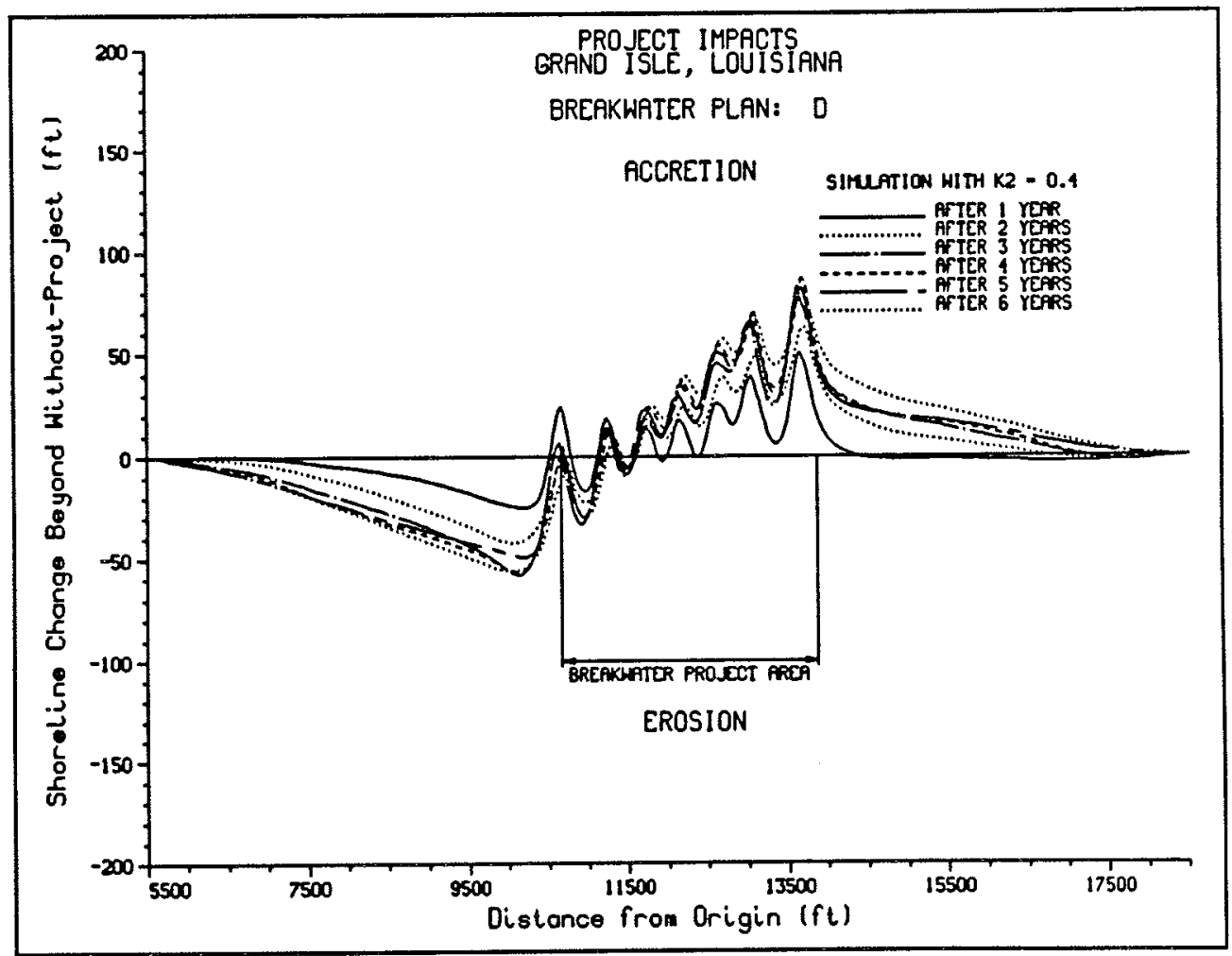

Figure 39. Project impacts, design configuration D (6-year simulation) 


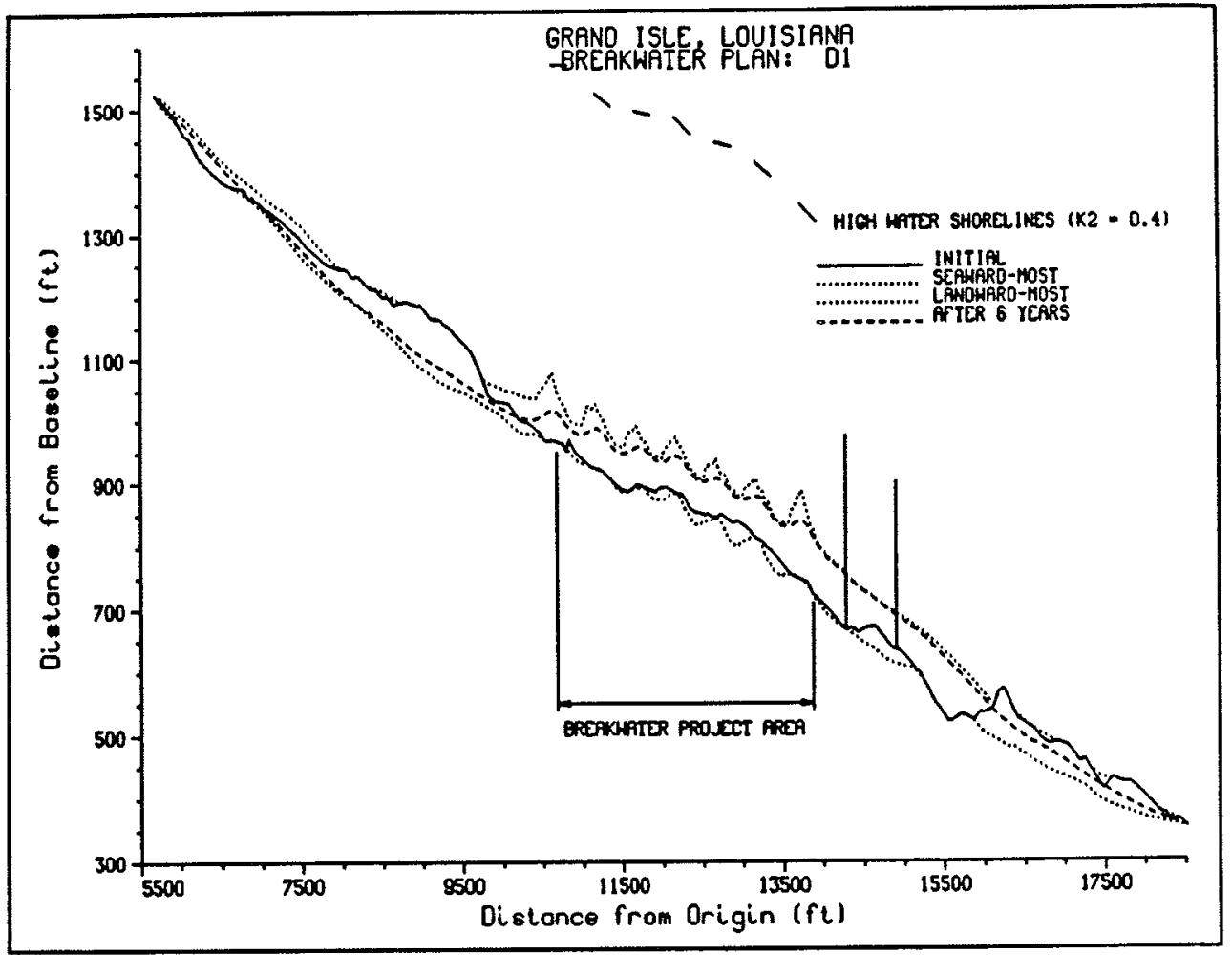

Figure 40. Breakwater design configuration D1 (6-year simulation)

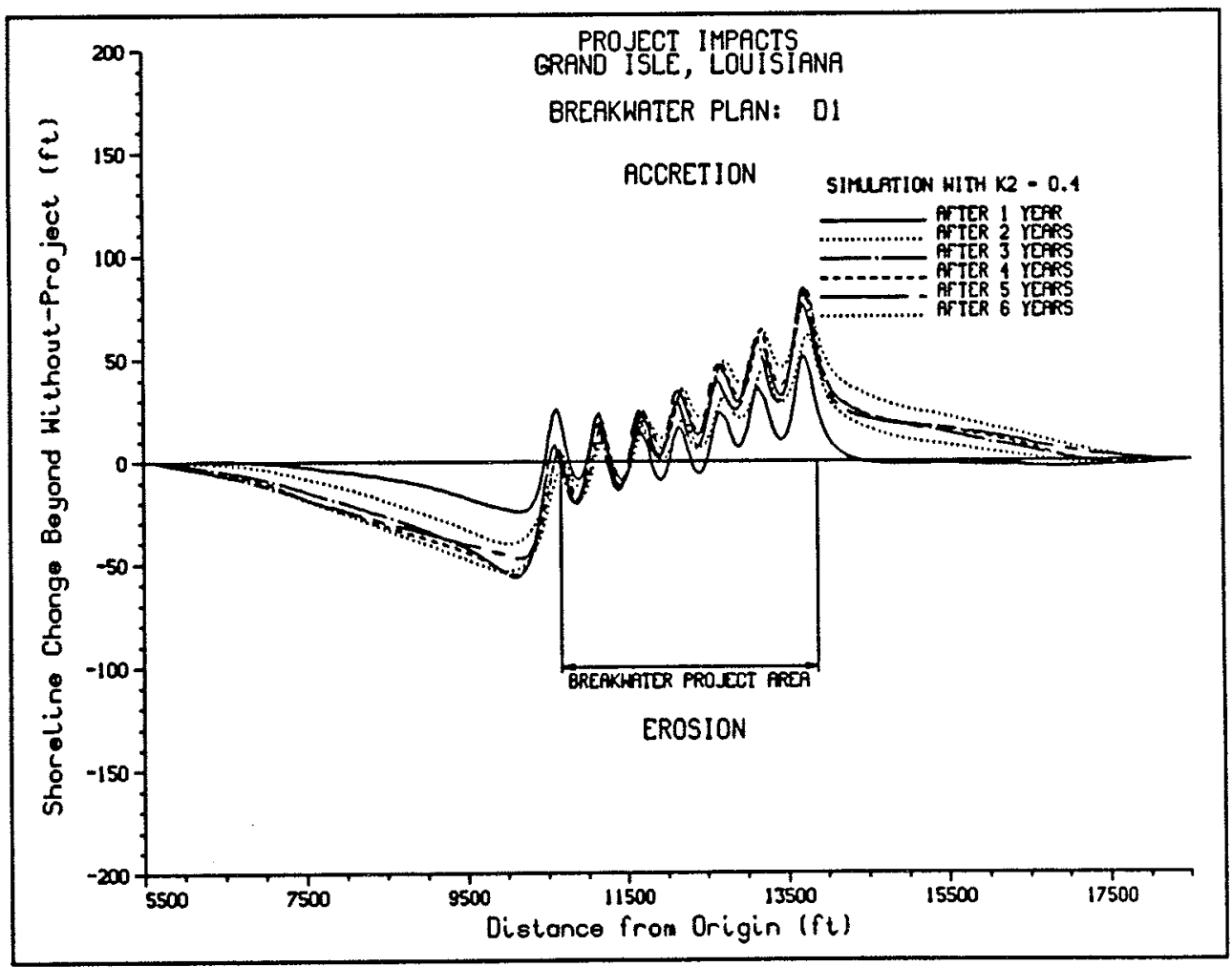

Figure 41. Project impacts, design configuration D1 (6-year simulation) 


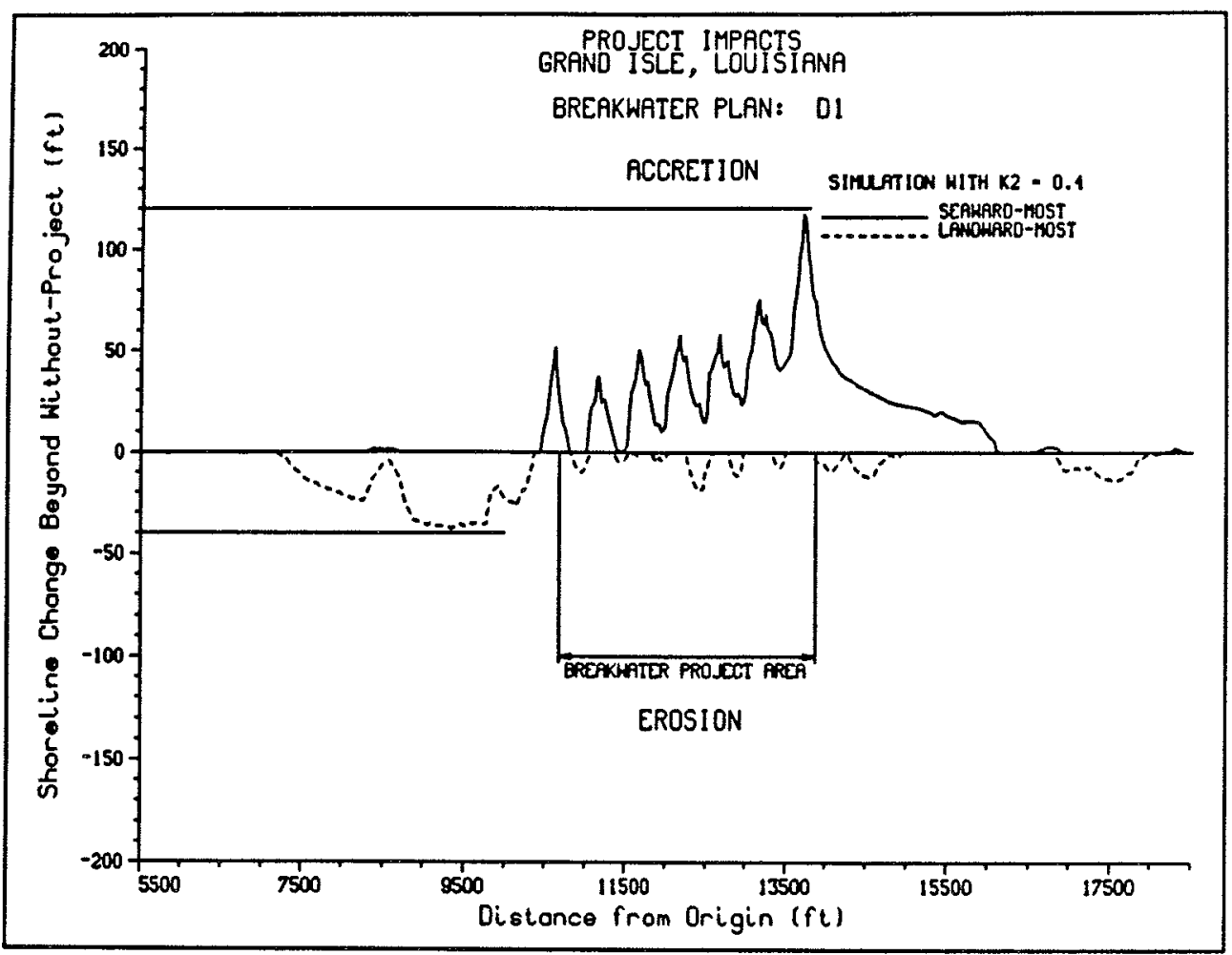

Figure 42. Maximum project impacts, design configuration D1

breakwaters. If beach nourishment proved to be effective, additional model simulations would be performed to estimate the quantity of beach fill material required, the optimum placement location, and the expected renourishment interval. These simulations were performed for proposed design configuration D1 (the most favorable design).

Several simulations using various beach fill quantities and placement locations were performed. Only the final recommended nourishment plan is presented herein. A renourishment interval of 4 years is recommended to conform to the renourishment interval of the ongoing shore protection plan at Grand Isle. The model simulations indicate that approximately $150,000 \mathrm{yd}^{3}$ of beach fill material, placed uniformly beginning approximately $1,700 \mathrm{ft}$ east of the eastern-most breakwater and extending to the west for an alongshore distance of approximately $2,300 \mathrm{ft}$, performs well and substantially reduces downdrift erosion problems.

Figures 45 through 48 summarize the results of the beach nourishment simulations for design configuration D1. Plotted in Figure 45 is the initial shoreline position (solid line), the seaward- and landward-most shoreline positions (dotted lines), the shoreline position after 4 years (chain-dot line), fill is placed uniformly along the shoreline in the designated beach fill reach at the beginning of year 1 and at the beginning of year 5 . Consequently the shoreline position after 4 years, the chain-dot line, characterizes the shoreline 


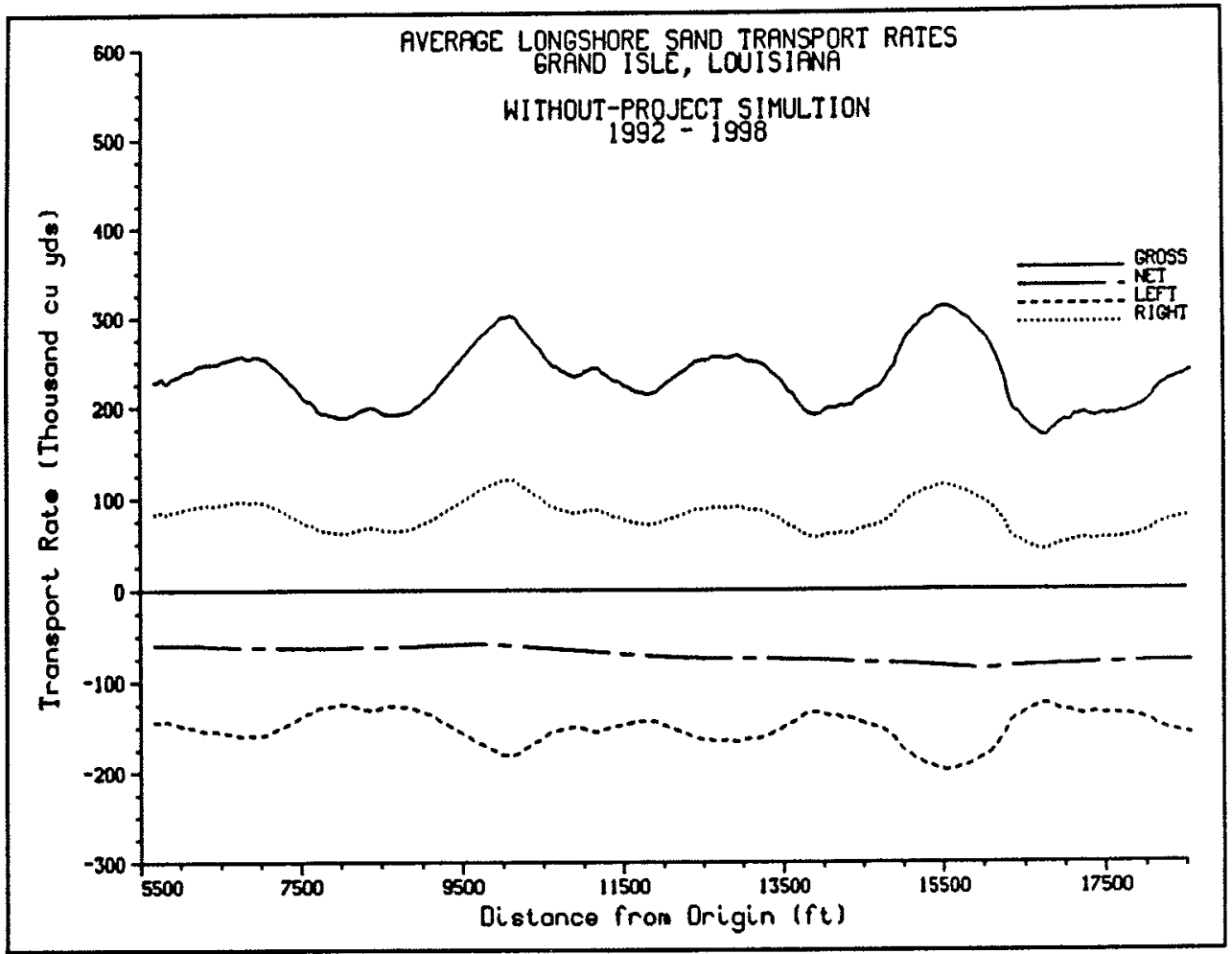

Figure 43. Average longshore sand transport rates (without-project simulation)

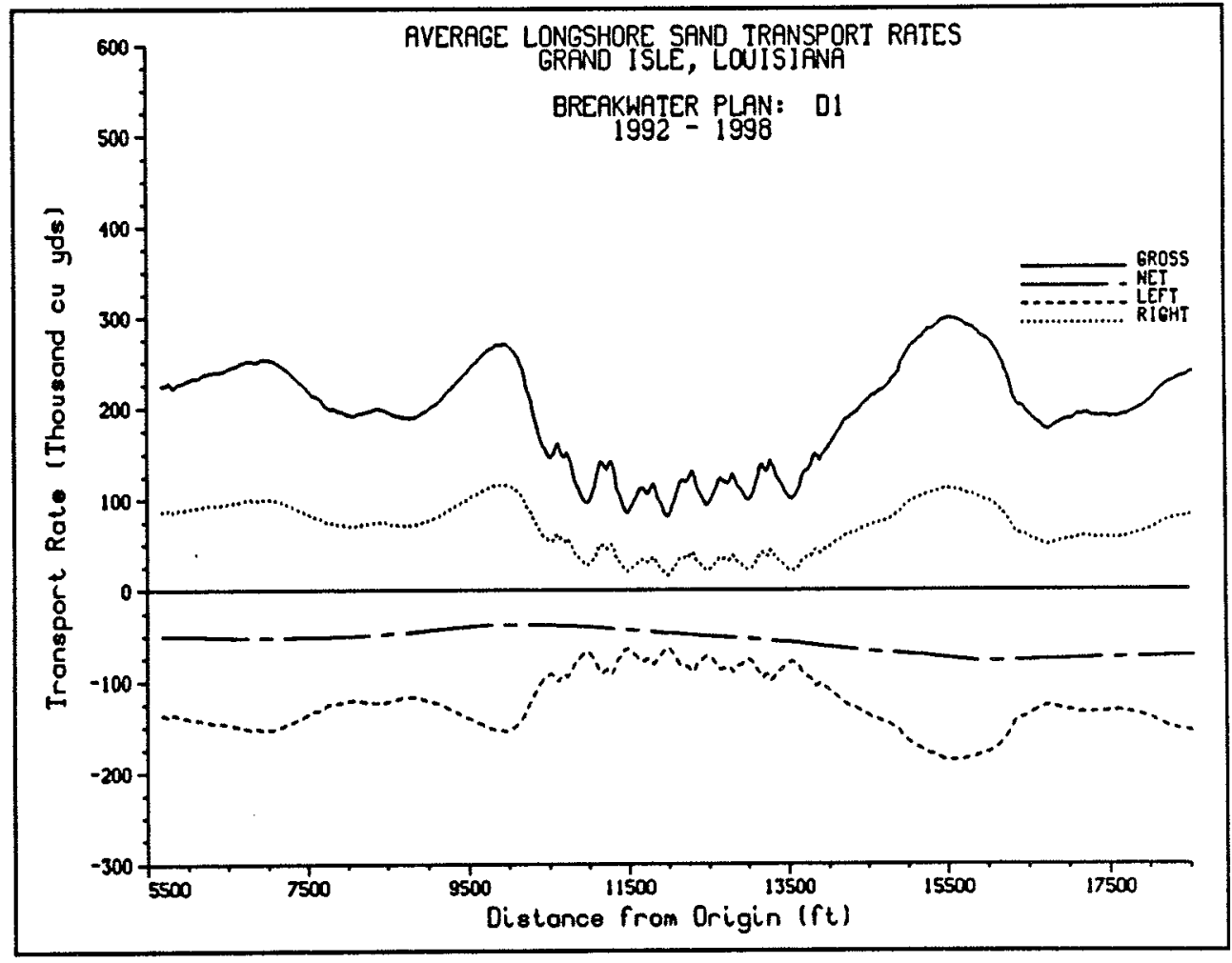

Figure 44. Average longshore sand transport rates (design configuration D1) 


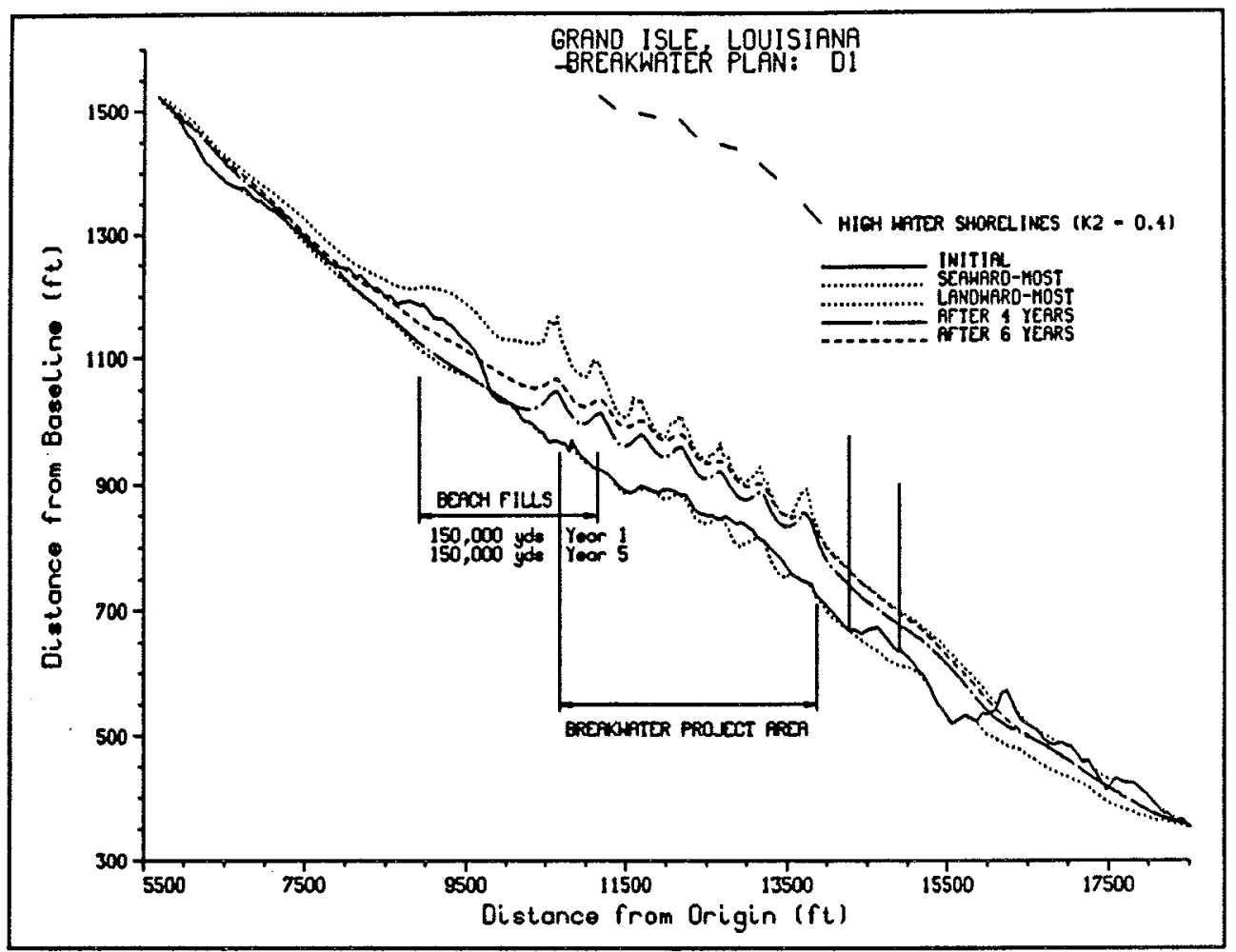

Figure 45. Design configuration D1 (beach nourishment simulation) at its most eroded state. The shoreline position after 6 years on the other hand, characterizes the shoreline in the middle of the renourishment cycle.

Figure 46 shows the calculated average annual longshore sand transport rates for the simulation. Comparing this plot with those shown in Figures 42 and 43 , it is seen that the placement of beach fill material allows longshore sand transport rates to transition back to the without project transport rates over a much shorter distance, thereby indicating that the fill material is sacrificial and not expected to remain in its placed location over the long term. Also of interest is the predicted location of minimum net longshore sand transport which now occurs behind the second breakwater from the east instead of the first. This shift in location of the minimum net transport rate results from the transport of a portion of the beach fill material into the breakwater project area.

Figure 47 shows the project impacts as compared to the without-project simulation. Of note is the more uniform development of the salient behind the breakwaters due to the addition of beach fill material along the eastern end of the project. The beach fill not only maintains the downdrift beaches but also provides material for the development of the salient on the east side of the breakwater project (compare Figures 47 and 39). Finally to assess the value of the proposed beach nourishment project the maximum project impacts are again examined as was done in Figure 42 . Figure 48 shows the maximum project impacts and it is seen that the maximum downdrift shoreline erosion is 


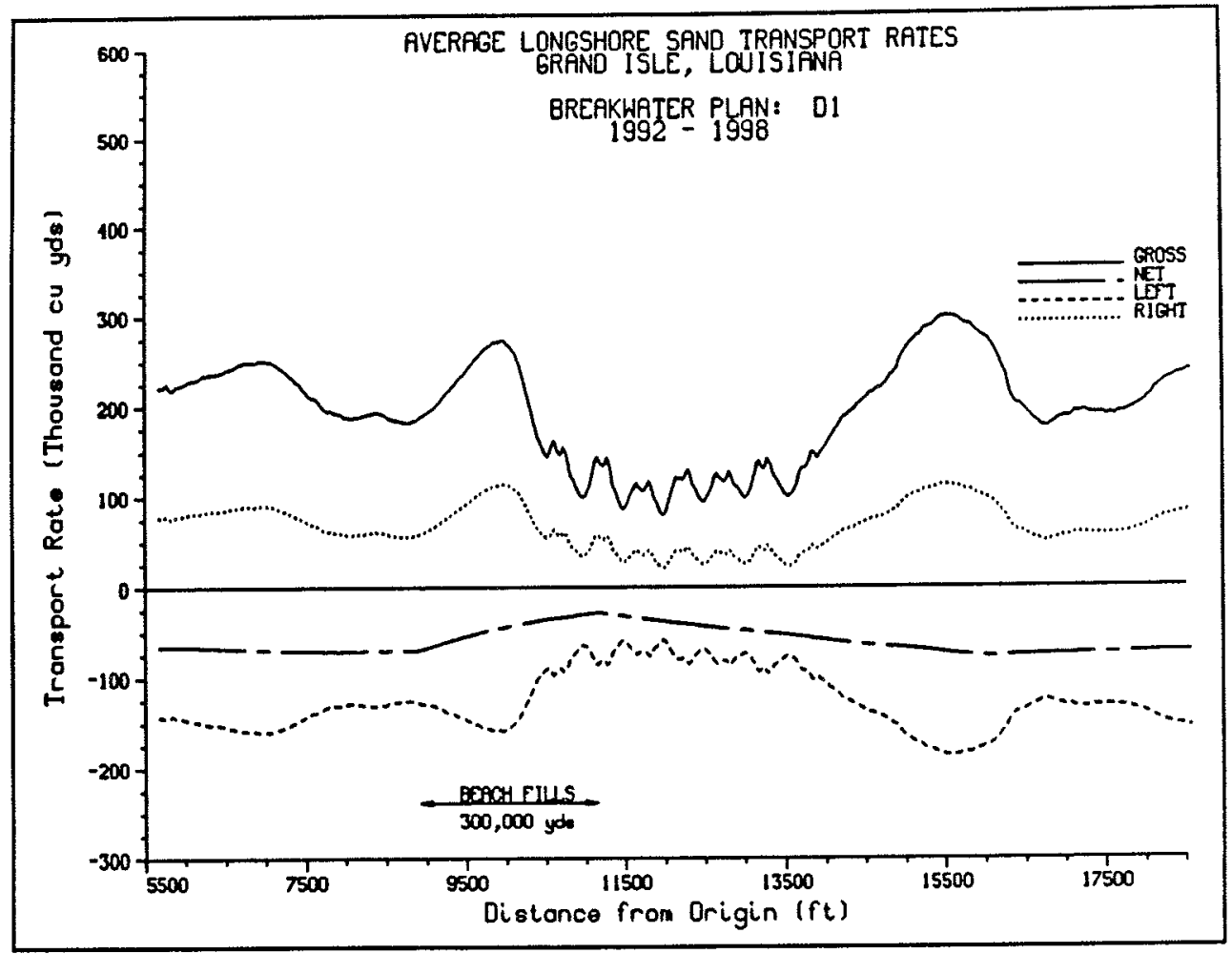

Figure 46. Average longshore sand transport rates (design D1 with beach fill)

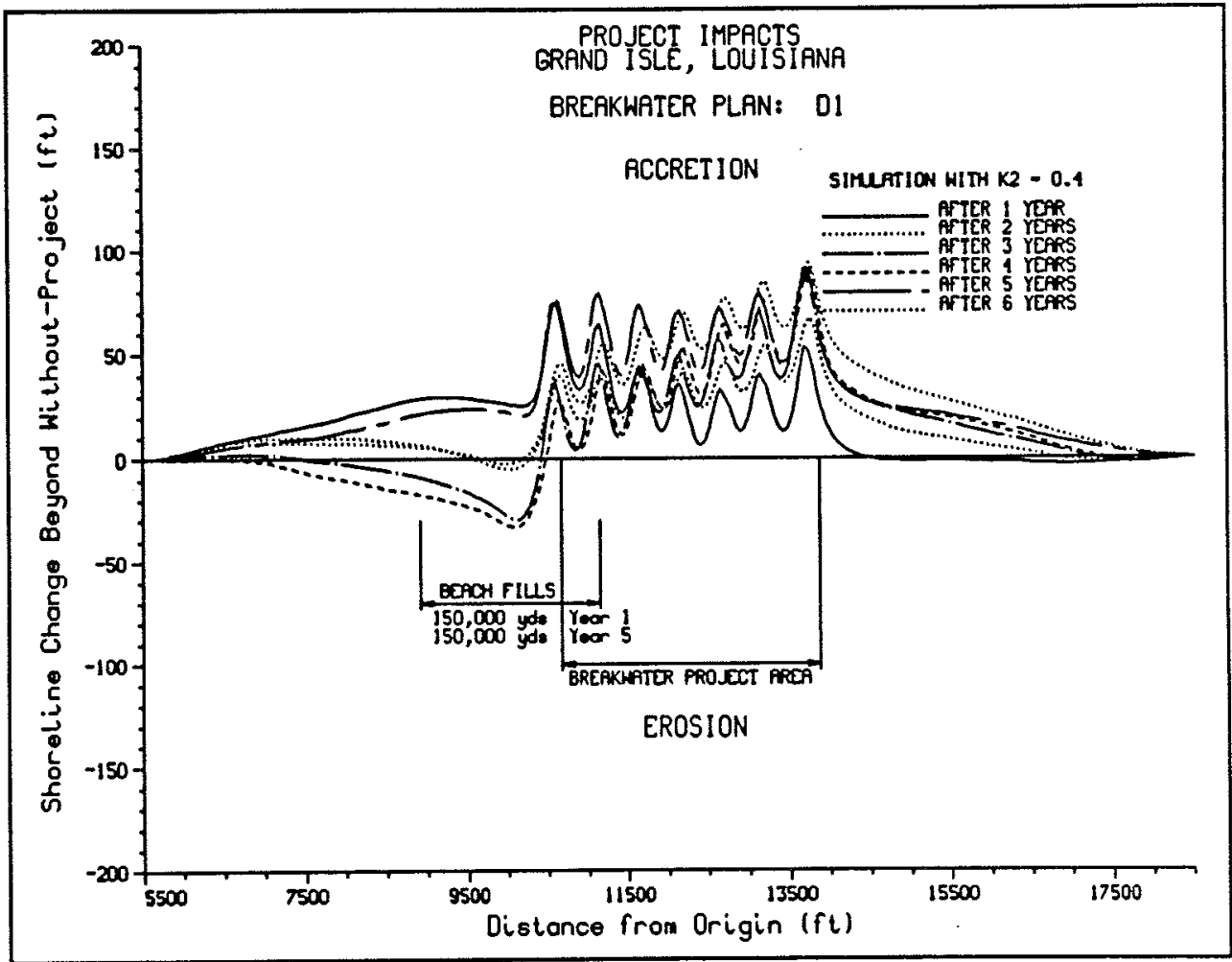

Figure 47. Project impacts, design configuration D1 with beach fill 


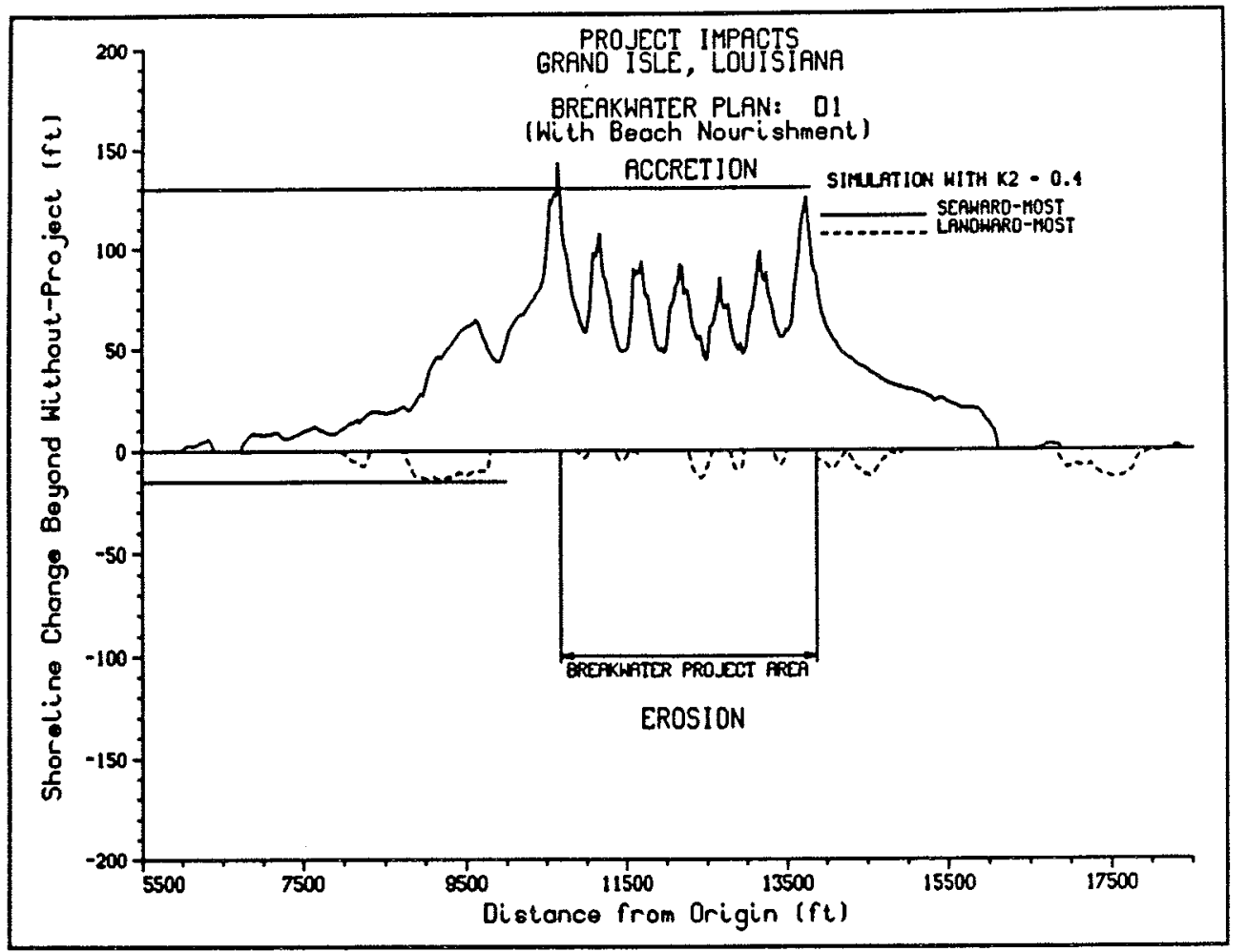

Figure 48. Maximum project impacts, design configuration D1 with beach fill reduced to less that $15 \mathrm{ft}$ compared to a previous result of approximately $40 \mathrm{ft}$. The maximum seaward advancement of the shoreline increases from $120 \mathrm{ft}$ to approximately $130 \mathrm{ft}$. Of perhaps greater importance is the more uniform development of the salient and the much greater alongshore distance that experiences at least periodic seaward advancement of the shoreline due to the proposed beach nourishment plan.

In summary, the influence of 12 proposed detached breakwater configurations on future shoreline change at Grand Isle was evaluated using the shoreline change model GENESIS. The results of the numerical simulations indicate that proposed design configuration D1 (described in Table 7) will not only reduce ongoing beach erosion, but provide for appreciable shoreline accretion for an alongshore distance of approximately 5,000 ft. Furthermore, if combined with a program of beach nourishment, expected downdrift erosion can be limited to an acceptable range. As a check on these numerically-generated estimates of shoreline response, empirically based breakwater design guidance and observed prototype shoreline responses at projects in similar environments were employed to provide other evaluations of project performance. The results of this analysis are presented in Chapter 4 of this report. 


\section{Empirical Analysis of Breakwater Design}

\section{Overview}

Based on GENESIS simulations, the performance of 12 detached breakwater design configurations were compared, and evaluated to determine which one provided protection to the project shoreline (approximately $3,300 \mathrm{ft}$ in length), while minimizing downdrift erosional impacts at Grand Isle, LA. To reiterate, design configuration $\mathrm{D} 1$ was determined to be the most favorable, and consists of seven breakwater segments with segment length $\mathrm{L}_{\mathrm{s}}=200 \mathrm{ft}$, placed in a water depth of approximately $\mathrm{d}=6 \mathrm{ft}$, and located a distance offshore of approximately $X=600 \mathrm{ft}$. Gap widths between breakwater segments are $350 \mathrm{ft}$ at the two ends of the project, and $300 \mathrm{ft}$ in the four middle gaps, therefore averaging $\mathrm{L}_{\mathrm{g}}=317 \mathrm{ft}$. Transmissibility of the breakwater segments was modeled in GENESIS with $\mathrm{K}_{\mathrm{T}}=50$ percent.

The morphologic response to design D1 (salient extending approximately $\mathrm{X}_{\mathrm{a}}=60$ to $80 \mathrm{ft}$ from the initial shoreline position) was compared with predictions using empirically based detached breakwater guidance and prototype response for projects in similar environments. This work provides added evaluations of project performance. Results of these comparisons are discussed herein.

\section{Louisiana Breakwater Projects}

Louisiana has one of the largest breakwater projects in the United States, with six segments constructed at Holly Beach in 1986 (one rubble-mound segment, and five other combinations of tires on pilings), another 55 segments completed in the summer of 1991 in Cameron Parish (all rubble-mound; six of these are positioned offshore of the original Holly Beach segments), and another 30 segments planned for construction (21 planned to continue the Cameron Parish project eastward and 9 more planned to extend it westward). Another very small rubble-mound project consisting of 4 segments exists at Grand Isle, constructed by direction of the Mayor of Grand Isle in 1989 (known and referred to herein as the Mayor's breakwater project). 
For the most part, these projects are all exposed to similar wave and sediment transport regimes, although the sediment transport direction at Grand Isle is from west to east, whereas in Cameron Parish it is from east to west. Net longshore sand transport rates at Grand Isle range from 50,000 to $125,000 \mathrm{yd}^{3} /$ year directed to the east, and in Cameron Parish it is approximately 62,000 to $100,000 \mathrm{yd}^{3} / y e a r$ directed to the west. With the exception of the original Holly Beach rubble-mound structure, the Cameron Parish project has rubble-mound structures constructed from 2,400 - to $6,000-\mathrm{lb}$ armor stone. The Grand Isle breakwaters are proposed with similar sized armor stone only (no core). The original Holly Beach rubble-mound breakwater had stone displaced during storms, due to its small size $(1,000$ to $1,500 \mathrm{lb}$ for 50 percent of structure weight). The Cameron Parish, Holly Beach rubble-mound segment and proposed Grand Isle breakwaters have a crest elevation of $+4 \mathrm{ft} \mathrm{msl}$. The tide range in Cameron Parish is slightly greater than that at Grand Isle (Cameron Parish, $2.0 \mathrm{ft}$ mean range and $2.4 \mathrm{ft}$ spring range; Grand Isle, $1.2 \mathrm{ft}$ mean range and $1.9 \mathrm{ft}$ spring range). There are also differences in the geologic setting of Cameron Parish and Grand Isle, thought to be relatively minor with respect to meso-time scales (1 to 20 years) and functional project performance.

Of primary interest is the range of morphologic shoreline response observed at these projects. The western Cameron Parish breakwater project appears to have had an impact on the beach, with morphologic shoreline response ranging from crescentic bar formations to the development of subdued salients, as shown in the oblique photos taken in July 1993 and presented in Figures 49 and 50. Profile data corresponding to the western Cameron Parish breakwaters from November 1992 to July 1993 indicate that beach response in the lee of the breakwater segments ranges from losses of $20 \mathrm{ft}$ (at the western-most (downdrift) breakwater) to gains of $20 \mathrm{ft}$ (11th breakwater from western terminus). For the most part, profile accretion is observed above and below 0 NGVD landward of the breakwaters, with losses offshore of the breakwaters. In the gap regions, losses of 10 to $30 \mathrm{ft}$ at $0 \mathrm{ft}$ NGVD are observed for the western-most regions, whereas a gain of $20 \mathrm{ft}$ occurred for a gap between the 7th and 8th breakwaters from the western terminus. The profile data examined, and aerial photographs shown in Figures 49 and 50 were taken 2 years after construction, and, because this section of the breakwater system is at the downdrift end of the project, it is most likely not yet at equilibrium. Shoreline change estimates stemming for the numerical investigation of the proposed Grand Isle project indicate that equilibrium conditions are achieved 3 to 4 years after construction.

The original Holly Beach project and the eastern part of the Cameron Parish project resulted in salient formation. Analysis of recent profiles surveyed at the eastern Cameron Parish project indicate a significant profile accretion occurred between August 1992 (pre-Hurricane Andrew) and November $1992 / J u l y ~ 1993$. Salient lengths in this region extend 10 to $120 \mathrm{ft}$ from the August 1992 shoreline, with accretions in the gap regions from 16 to $50 \mathrm{ft}$. These observed salient lengths compare well with the numerically 


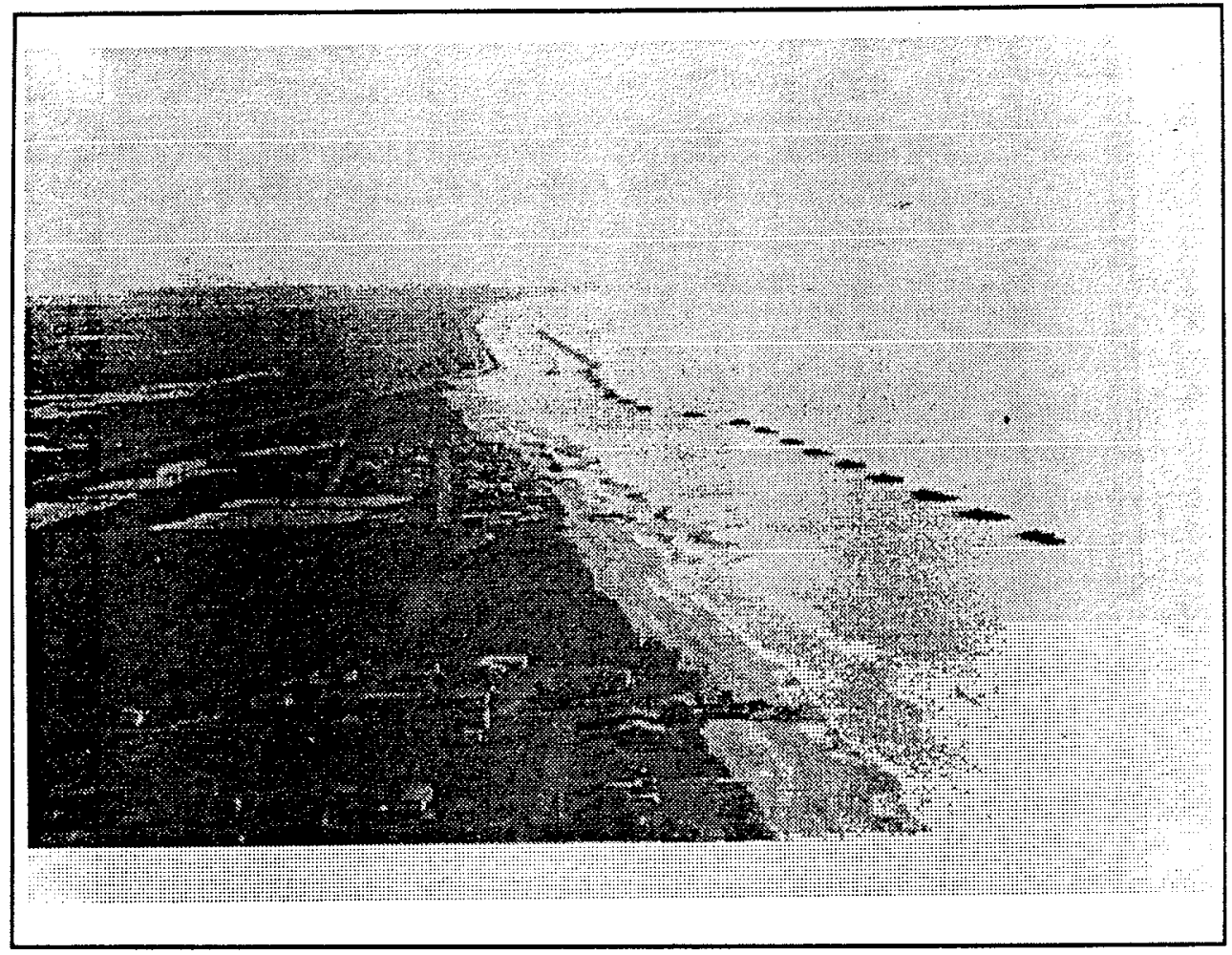

Figure 49. Crescentic bars at the western Cameron Parish breakwater project

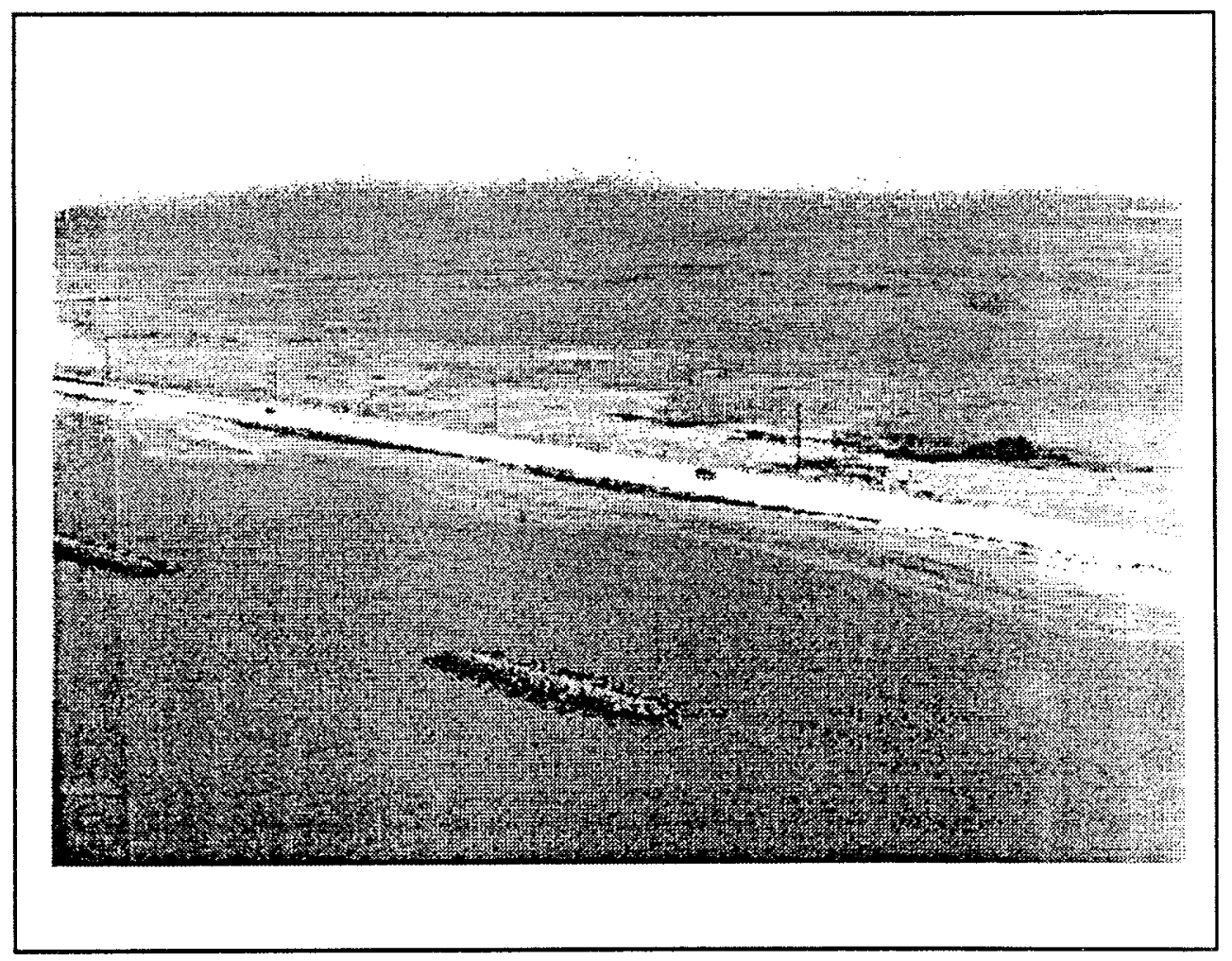

Figure 50. Subdued salient at western Cameron Parish breakwater project 
predicted salient lengths (between 60 and $80 \mathrm{ft}$ ) for breakwater design configuration D1.

A low tide tombolo formed at the Mayor's breakwater project on Grand Isle between its completion in November 1989 and the August 1992 aerial photographs. This morphologic evolution, however, may be more of a result of the 1990 Grand Isle beach renourishment than of the breakwater project itself.

Table 10 compares various functional parameters for each of the projects, and their morphological response. Note that the functional design parameter of structure length to distance offshore $\left(\mathrm{L}_{\mathrm{a}} / \mathrm{X}\right)$ for Grand Isle design configuration D1 lies between those for the West Cameron Parish and East Cameron Parish projects. This means that the blocking of wave energy (as related only to breakwater length and distance offshore) and resulting shoreline response for the proposed Grand Isle project should fall between the observed shoreline responses at the eastern and western ends of the Cameron Parish project. On the other hand, the other function design parameter, structure length to gap length $\left(\mathrm{L}_{\mathrm{a}} / \mathrm{L}_{\mathrm{g}}\right)$ for Grand Isle design configuration D1 is lower than both the East and West Cameron Parish projects, which means that a greater amount of wave energy blocking and consequently, greater influence on shoreline change should occur at the proposed Grand Isle project than is occurring at the Cameron Parish projects. These observations tend to support the results of the numerical shoreline change estimates which indicate that the seaward extension of the salient will equilibrate between 60 and $80 \mathrm{ft}$ from the initial shoreline position. Simulations that included downdrift beach

\begin{tabular}{|c|c|c|c|c|c|c|c|}
\hline Project/Design & L. (ft) & $L_{0}(f t)$ & $X(f t)$ & $\begin{array}{l}\text { Depth } \\
\text { (ft) }\end{array}$ & $L, L_{0}$ & L. $/ X$ & $\begin{array}{l}\text { Observed } \\
\text { Response }\end{array}$ \\
\hline $\begin{array}{l}\text { West Cameron Parish } \\
\text { Project }\end{array}$ & 150 & 290 & 560 & 6 & 1.9 & 0.27 & $\begin{array}{l}\operatorname{minor} \\
\left(X_{x}--20\right. \\
\text { to } 20 \mathrm{ft})\end{array}$ \\
\hline $\begin{array}{l}\text { East Cameron Parish } \\
\text { Project }\end{array}$ & 150 & 300 & 360 & 6 & 2 & 0.42 & $\begin{array}{l}\text { salient } \\
\left(X_{t}-10 \text { to }\right. \\
120 \mathrm{ft})\end{array}$ \\
\hline $\begin{array}{l}\text { Old Holly Beach } \\
\text { Project, rubble-mound } \\
\text { structure }\end{array}$ & 150 & 300 & 240 & 6 & 2 & 0.63 & $\begin{array}{l}\text { salient/ low } \\
\text { tide } \\
\text { tombolo }\end{array}$ \\
\hline $\begin{array}{l}\text { Mayor's Project, } \\
\text { Grand Isle }\end{array}$ & 70 & 70 & 350 & 3.5 & 1 & 0.20 & tombolo \\
\hline Design D1, Grand Isle & 200 & 317 & 600 & 6 & 1.6 & 0.33 & $\begin{array}{l}\text { predicted } \\
\text { salient } \\
\left(X_{4}-60 \text { to }\right. \\
80 \mathrm{ft})\end{array}$ \\
\hline
\end{tabular}


nourishment show that the seaward extension of the salient equilibrates an additional $20 \mathrm{ft}$ seaward for a total of between 80 and $100 \mathrm{ft}$ from the initial shoreline position. Overall, the comparison of the numerically predicted shoreline response is quite compatible with the observed shoreline responses at the Cameron Parish project with regard to the functional design parameters of structure length to distance offshore and structure length to gap length.

\section{Empirical Predictions of D1 and Louisiana Breakwater Project Response}

Many empirical relationships have been developed to predict the morphological response of a detached breakwater project as a function of functional design parameters. Note that these relationships do not account for many variables which affect beach response to breakwaters (i.e., net and gross longshore sand transport rates, structure transmissibility, wave climate, beach slope, etc.). Relationships applied herein are either based on all prototype or a combination of laboratory and prototype data, as summarized by Rosati (1990). Guidance developed for pocket beach or headland breakwaters has not been applied.

These empirical relationships were used to predict beach response to proposed design configuration $\mathrm{D} 1$, and to compare with observed response at the four other groups of detached breakwater segments along the Louisiana coast. The most common empirical relationship, relates the structure length $L_{\text {s }}$ to the structure distance offshore from the original shoreline, $X$. Table 11 summarizes the comparison of this parameter for all Louisiana projects.

Of the eight studies recommending ranges of $\mathrm{L}_{\mathbf{a}} / \mathrm{X}$, three predict that the shoreline response to design configuration D1, the West Cameron Parish breakwaters, and the Mayor's project on Grand Isle will be minimal (Inman and Frautschy 1966; Nir 1982; Ahrens and Cox unpublished). For the most part, these references indicate that the East Cameron Parish and Holly Beach project will have some accretion. Gourlay (1981) and the SPM (1984) indicate that tombolo formation will not occur for design configuration D1, or any of the other Louisiana projects. The Holly Beach rubble-mound structure is the only project that falls within Dally and Pope's (1986) recommended $\mathrm{L}_{5} / \mathrm{X}$ range for "salient" formation; all other projects fall between two recommended ranges, implying that the beach response will be between "uniform protection" for the segmented system (only one salient rather than seven distinct forms), and salient formation. Noble (1978) presents a relationship for minimal impact, and all projects are outside this range, indicating that there will be some impact of the project on the beach. All projects fall outside Toyoshima's $(1972,1974)$ recommended range of $L_{b} / X$.

To summarize, these empirical relationships for $\mathrm{L}_{\mathbf{b}} / \mathrm{X}$ are, at best, mediocre predictors of beach response for the Louisiana coast breakwaters. Most of the empirical guidance suggests that design configuration D1 as well 


\begin{tabular}{|c|c|c|c|c|c|}
\hline \multirow[t]{2}{*}{ Reference } & \multicolumn{5}{|c|}{ Project and Observed/Predicted Morphologic Response } \\
\hline & $\begin{array}{l}\text { West } \\
\text { Cameron } \\
\text { Parish -- } \\
\text { minor } \\
\text { response }\end{array}$ & $\begin{array}{l}\text { East Cameron } \\
\text { Parish -- } \\
\text { salient }\end{array}$ & $\begin{array}{l}\text { Old Holly } \\
\text { Beach, rubble- } \\
\text { mound .- } \\
\text { salient }\end{array}$ & $\begin{array}{l}\text { Mayor's Pro- } \\
\text { ject, Grand } \\
\text { Isle -- } \\
\text { tombolo }\end{array}$ & $\begin{array}{l}\text { Design D1, } \\
\text { Grand Isle -- } \\
\text { salient }\end{array}$ \\
\hline $\begin{array}{l}\text { Inman and } \\
\text { Frautschy (1966) }\end{array}$ & $\begin{array}{l}\text { "no pro- } \\
\text { nounced } \\
\text { accretion" }\end{array}$ & "accretion" & "accretion" & $\begin{array}{l}\text { "no pro- } \\
\text { nounced } \\
\text { accretion" }\end{array}$ & $\begin{array}{l}\text { "no pro- } \\
\text { nounced } \\
\text { accretion" }\end{array}$ \\
\hline Nir (1982) & $\begin{array}{l}\text { "non-depo- } \\
\text { sitional" }\end{array}$ & $\begin{array}{l}\text { "non-depo- } \\
\text { sitional" }\end{array}$ & "depositional" & $\begin{array}{l}\text { "non-depo- } \\
\text { sitional" } \\
\end{array}$ & $\begin{array}{l}\text { "non-deposi- } \\
\text { tional" }\end{array}$ \\
\hline Gourlay (1981) & no tombolo & no tombolo & no tombolo & no tombolo & no tombolo \\
\hline SPM (1984) & no tombolo & no tombolo & no tombolo & no tombolo & no tombolo \\
\hline $\begin{array}{l}\text { Dally and Pope } \\
\text { (1986) }\end{array}$ & $\begin{array}{l}\text { between } \\
\text { "salient" and } \\
\text { "uniform } \\
\text { response" }\end{array}$ & $\begin{array}{l}\text { between "sa- } \\
\text { lient" and } \\
\text { "uniform re- } \\
\text { sponse", }\end{array}$ & "salient" & $\begin{array}{l}\text { between } \\
\text { "salient" and } \\
\text { "uniform } \\
\text { response" }\end{array}$ & $\begin{array}{l}\text { between } \\
\text { "salient" and } \\
\text { "uniform } \\
\text { response" }\end{array}$ \\
\hline $\begin{array}{l}\text { Toyoshima (1972. } \\
\text { 1974) }\end{array}$ & $\begin{array}{l}\text { outside } \\
\text { recommended } \\
L_{s} / X \text { range }\end{array}$ & $\begin{array}{l}\text { outside recom- } \\
\text { mended } L_{1} / X \\
\text { range }\end{array}$ & $\begin{array}{l}\text { outside recom- } \\
\text { mended } L_{a} / X \\
\text { range }\end{array}$ & $\begin{array}{l}\text { outside rec- } \\
\text { ommended } \\
L_{S} / X \text { range }\end{array}$ & $\begin{array}{l}\text { outside rec- } \\
\text { ommended } \\
\mathrm{L}_{8} / \mathrm{X} \text { range }\end{array}$ \\
\hline $\begin{array}{l}\text { Ahrens and Cox } \\
\text { (unpublished) }\end{array}$ & "no sinuosity" & $\begin{array}{l}\text { between "no } \\
\text { sinuosity" and } \\
\text { "subdued } \\
\text { salient" }\end{array}$ & $\begin{array}{l}\text { between "no } \\
\text { sinuosity" and } \\
\text { "subdued sa- } \\
\text { lient" }\end{array}$ & "no sinuosity" & "no sinuosity" \\
\hline Noble (1978) & $\begin{array}{l}\text { more than } \\
\text { "minimal } \\
\text { impect" }\end{array}$ & $\begin{array}{l}\text { more than } \\
\text { "minimal } \\
\text { impact" }\end{array}$ & $\begin{array}{l}\text { more than } \\
\text { "minimal im- } \\
\text { pact" }\end{array}$ & $\begin{array}{l}\text { more than } \\
\text { "minimal } \\
\text { impact" }\end{array}$ & $\begin{array}{l}\text { more than } \\
\text { "minimal } \\
\text { impact" }\end{array}$ \\
\hline
\end{tabular}

as the eastern and western ends of the Cameron Parish project will have little or no influence on shoreline change (or that the breakwaters are located too far offshore), however, the observed shoreline response at the Cameron Parish projects conflicts with this suggestion. Also, the Mayor's project on Grand Isle, is predicted by all but one reference to have a minimal impact; yet observed beach response is a tombolo. However, as stated before, the 1990 beach renourishment of Grand Isle may have masked the actual influence of this breakwater project. The very mild beach slope for the Louisiana coast projects (1V:70H to $1 \mathrm{~V}: 100 \mathrm{H})$ as compared to a "typical" detached breakwater beach slopes $(\sim 1 \mathrm{~V}: 20 \mathrm{H}$ to $1 \mathrm{~V}: 30 \mathrm{H})$, which are inherent in the empirical guidance, most likely affects the predictive ability of these relationships for the Louisiana coast.

Several additional empirical relationships were used to evaluate design configuration D1. Design configuration D1 is outside the prototype database 
used to develop Pope and Dean's (1986) plot of morphologic response as a function of several project variables; however, the trend of the plot indicates that the beach response will be "no sinuosity." Seiji, Uda, and Tanaka (1987) predict that there will be "no erosion opposite the gap." Suh and Dalrymple (1987) predict a salient length (distance from original shoreline to salient tip) of $\mathrm{X}_{\mathrm{t}}=90 \mathrm{ft}$, comparable to that predicted by GENESIS. Suh and Dalrymple (1987) also predict that tombolos will not form. Harris and Herbich's (1986) relationship indicates that approximately $115 \mathrm{yd}^{3}$ will be deposited to the lee of each breakwater segment, totaling approximately $800 \mathrm{yd}^{3}$ for the project; however, design configuration D1 is slightly outside the range of the database with which this relationship was developed. For comparison, GENESIS predicts between 125,000 and $135,000 \mathrm{yd}^{3}$ of total accretion.

The Japanese Ministry of Construction (JMC) (1986) methodology provides a step-by-step procedure for determining functional breakwater design parameters based on the performance of approximately 1,600 detached breakwater projects in Japan which were constructed of armor units. Sixty percent of the Japanese detached breakwater projects surveyed had tombolo formation, and thus the methodology will most likely result in a design that will produce tombolo formation. The mildest slope recommended for use with the JMC method is $1 \mathrm{~V}: 30 \mathrm{H}$; beach slopes at Grand Isle are from $1 \mathrm{~V}: 70 \mathrm{H}$ to $1 \mathrm{~V}: 100 \mathrm{H}$. However, profiles drawn for "Beach Type B" in the JMC method indicate slopes as mild as $1 \mathrm{~V}: 70 \mathrm{H}$; therefore, it is expected that data from this beach type would be reasonable to apply to Grand Isle.

Using a deepwater wave height corresponding to the five highest non-storm waves in a year, $\mathrm{H}_{o 5}=4 \mathrm{ft}$, corresponding wave period $\mathrm{T}_{5}=6 \mathrm{sec}$, and design salient length $\mathrm{X}_{4}=80 \mathrm{ft}$ (similar to D1), the JMC method indicates that 14 breakwater segments should be constructed to protect the $3,300 \mathrm{ft}$ of project beach, with segment length $\mathrm{L}_{\mathrm{s}}=150 \mathrm{ft}$, gap distance $\mathrm{L}_{\mathrm{g}}=90 \mathrm{ft}$, approximately $X=150 \mathrm{ft}$ offshore, in a water depth $\mathrm{d}=2.5 \mathrm{ft}$. This result is not unusual; the JMC method has been observed to give shorter structure segments that are positioned closer to shore than U.S. detached breakwater projects (Rosati and Truitt 1990, Rosati 1990). Most of the simple empirical relationships predict tombolo formation for this segment-to-distance offshore ratio.

\section{Comparison with Projects in Similar Environments}

Probably the best indication of whether a breakwater design will perform as desired is to use data from a project in a similar environment, or construct a prototype test to evaluate the design prior to final project design and construction. Comparison of the $\mathrm{L}_{\mathbf{a}} / \mathrm{X}$ and $\mathrm{L}_{\mathrm{B}} / \mathrm{L}_{\mathbf{b}}$ ratios for $\mathrm{D} 1$ and other Louisiana project can indicate the probable response to the proposed Grand Isle design. Design configuration $D 1$ 's $\mathrm{L}_{\mathbf{s}} / \mathrm{X}$ ratio falls between that of the west and east Cameron Parish breakwaters, indicating that beach response 
would be somewhere between "minor" (although this observation is most likely before equilibrium has occurred at east Cameron Parish), and "salient." However, D1's $\mathrm{L}_{\mathrm{g}} / \mathrm{L}_{\mathbf{a}}$ ratio is slightly lower than at the Cameron Parish structures, indicating that $\mathrm{D} 1$ will provide more protection to the project shoreline than the Cameron Parish project. Thus, comparison of these two ratios indicates that $\mathrm{D} 1$ will most likely produce some response on the project beach, probably more than "minor" and less than or equal to "salient." Of course, there are many other variables that vary between these projects, and are not included in this simple comparison (i.e., net and gross longshore sand transport rates, structure transmission due to the different cross-sectional design, tide range, effects of storms, differences in local beach slope, etc.). Ultimately, the effects of these other variables may alter the expected response.

The extent and magnitude of downdrift impacts are necessary considerations in the design of detached breakwater projects. To minimize these impacts, beach fill should be placed at the time of breakwater construction. In addition, segments located at the downdrift end of the project site could be moved offshore slightly, and gap distances increased. Using this type of design, the downdrift beach would be provided some protection while allowing longshore sand transport rates to return to their non-project magnitudes. This would reduce, not eliminate, the downdrift impacts. 


\section{Summary and Recommendations}

In the study described and presented in this report, general coastal processes, and specifically, shoreline response to a series of segmented detached breakwaters constructed offshore of Grand Isle were investigated to assist LMN in their development of a design of beach erosion control and hurricane protection for this important Louisiana barrier island. The investigation involved a review of the geologic framework in which the island developed and its long-term geomorphic evolution, a statistical analysis of the incident wave climate, detailed nearshore wave transformation analysis, numerical shoreline change investigations, and an empirical analysis of the functional design characteristics of the proposed breakwater project together with comparisons to other breakwater projects in Louisiana. This chapter summarizes the study and discusses recommendations made to LMN concerning the proposed detached breakwater project at Grand Isle.

\section{Long-Term Shoreline Change}

A major part of this study was the numerical simulation of shoreline response to the proposed detached breakwater projects at Grand Isle. The purpose of this task was to estimate the influence of a series of segmented detached breakwaters on shoreline evolution within and adjacent to the project reach. The shoreline evolution model GENESIS, was used in this part of the study and the shoreline response to a total of twelve different breakwater project configurations was estimated. The results of the numerical simulations indicate that a system of segmented detached breakwaters constructed offshore of Grand Isle will have a significant impact on future shoreline change. In general, this impact can be characterized as one of significant shoreline accretion directly in the lee of the breakwater project coupled with shoreline erosion downdrift (to the east) and moderate shoreline accretion updrift (to the west) of the project. Through multiple simulations of increasing duration it was estimated that the shoreline will progressively respond to the breakwaters for a period of about 3 or 4 years after which general equilibrium conditions will be achieved with respect to shoreline change. Additional simulations were performed to investigate the quantity of beach fill material required to 
maintain the shoreline downdrift of the breakwater project where shoreline erosion is expected. The results of these simulations indicated that a beach nourishment program involving the uniform placement of approximately $150,000 \mathrm{yd}^{3}$ every 4 years in a reach beginning approximately $1,700 \mathrm{ft}$ east of the eastern-most breakwater and extending to the west for an alongshore distance of about $2,300 \mathrm{ft}$ will in general maintain the downdrift shoreline at positions seaward of the 1990 shoreline position. Breakwater design configuration D1 (details of the project configuration are given in Table 7, Chapter 3) was determined to be the most favorable project configuration of the 12 proposed project configurations.

It should be noted that the numerical shoreline evolution estimates presented and discussed herein are based on longshore sand transport processes associated with normal non-storm wave conditions contained in the representative time series of wave conditions used as input to the shoreline change model. During storm events such as hurricanes, the breakwaters are expected to intercept a portion of the incoming wave energy which will reduce the amount of wave energy finally expended on the beach and thereby reduce to some extent the magnitude of beach erosion behind the breakwaters. Furthermore, if the shoreline has responded to the breakwater project in the manner predicted herein prior to the impact of the hurricane the added beach width resulting from shoreline accretion behind the breakwaters will provide an additional measure of storm damage protection for the shoreline reach behind the breakwaters.

In conclusion, the results of the numerical simulations of shoreline change in response to detached breakwaters at Grand Isle, Louisiana indicate that proposed breakwater design configuration D1 will not only reduce ongoing beach erosion, but provide for appreciable shoreline accretion for an alongshore distance of approximately $5,000 \mathrm{ft}$. Furthermore, if construction of the breakwater project is combined with a program of beach nourishment, downdrift erosional impacts can be minimized and beach fill placement is therefore recommended.

\section{Empirical Analysis of Breakwater Design}

An empirical analysis of the functional design characteristics of the recommended breakwater design configuration was performed as part of this study to provide verification of the numerically-generated results. This part of the study also compared the proposed project to existing projects in Louisiana and evaluated these other project using available empirical design guidance. The major conclusion of this part of the study is that the available empirical breakwater design guidance provides a relatively poor indicator of actual beach response to breakwaters along the Louisiana coast. This conclusion was primarily based on estimates of shoreline response obtained from the empirical design guidance compared to observed shoreline response at the Cameron Parish breakwater project. The empirical relationships predicted that the 
shoreline response to the Cameron Parish project (as well as the proposed Grand Isle) would be minimal, whereas, observations show that salients extending from 10 to $120 \mathrm{ft}$ seaward have formed in the lee of the breakwaters. These observed salient lengths compare well with the numerically predicted salient lengths of between 60 and $80 \mathrm{ft}$ for the recommended breakwater design configuration D1. Comparing the ratio of structure length to distance offshore for the proposed breakwater project at Grand Isle with the existing breakwater project at Cameron Parish indicates that the Grand Isle project should produce shoreline changes between those observed at the eastern Cameron Parish project (between 10 and $120 \mathrm{ft}$ of salient accretion) and the western Cameron Parish project (between -20 and 20 $\mathrm{ft}$ of salient accretion). Based on the ratio of structure length to gap length, the proposed Grand Isle breakwater project should produce more pronounced salient formation than the Cameron Parish projects.

In conclusion, the available empirical breakwater design guidance suggests that the magnitude of shoreline response predicted numerically using the GENESIS model is over-predicted. However, observed shoreline response at the Cameron Parish project exceeds the shoreline response predicted using the empirical guidance and tends to agree well with the GENESIS results. Finally, prototype experience is typically the best available indicator of shoreline response to breakwaters and because of the environmental similarities (mild beach slope, wave climate, tide range, etc.) between Grand Isle and Cameron Parish it is recommended that the Cameron Parish breakwater project be used as a model for designing the Grand Isle breakwater project. 


\section{References}

Ahrens, J. P., and Cox, J., "Design and Performance of Reef Breakwaters," submitted to Journal of Coastal Research, in press.

Combe, A. J., and Soileau, C. W., 1987, "Behavior of man-made beach and dune at Grand Isle, Louisiana," Proceedings Coastal Sediments '87, American Society of Civil Engineers, p. 1232-1242.

Dally, W. R., and Pope, J., 1986, "Detached Breakwaters for Shore Protection," Technical Report CERC-86-1, U.S. Army Engineer Waterways Experiment Station, Vicksburg, MS.

Ebersole, B. A., Cialone, M. A., and Prater, M. D., 1986, "RCPWAVE - A Linear Wave Propagation Model for Engineering Use," Technical Report CERC-86-4, U.S. Army Engineer Waterways Experiment Station, Vicksburg, MS.

Gourlay, M. R., 1981, "Beach Processes in the Vicinity of Offshore Breakwaters," Proceedings Fifth Australian Conference on Coastal and Ocean Engineering, pp 129-134.

Gravens, M. B., and Kraus, N. C., 1989, "Representation of Groins in Numerical Models of Shoreline Response," Proceedings of the XXIII Congress Hydraulics and the Environment, International Association for Hydraulic Research, pp C515-C522.

Gravens, M. B., Kraus, N. C., and Hanson, H., 1991, "GENESIS: Generalized Model of Simulating Shoreline Change, Report 2, Workbook and System User's Manual," Technical Report CERC-89-19, U.S. Army Engineer Waterways Experiment Station, Vicksburg, MS.

Hallermeier, R. F., 1979, "Uses for a Calculated Limit Depth to Beach Erosion," Proceedings 16th Coastal Engineering Conference, American Society of Civil Engineers, pp 1493-1512.

, 1983, "Sand Transport Limits in Coastal Structure Designs," Proceedings Coastal Structures '83, American Society of Civil Engineers, pp 703-716.

Hanson, H. 1987, "GENESIS - a Generalized Shoreline Change Model for Engineering Use," Report No. 1007, Department of Water Resources Engineering, University of Lund, Lund, Sweden. 
Hanson, H., and Kraus, N. C., 1980, "Numerical Model for Studying Shoreline Change in the Vicinity of Coastal Structures," Report No. 3040, Department of Water Resources Engineering, University of Lund, Lund, Sweden.

, 1989, "GENESIS: Generalized Model for Simulating Shoreline Change; Report 1, Technical Reference," Technical Report CERC-89-19, U.S. Army Engineer Waterways Experiment Station, Vicksburg, MS.

Hanson, H., Kraus, N. C., and Nakashima, L. D., 1989, "Shoreline Change Behind Transmissive Detached Breakwaters," Proceedings Coastal Zone '89, American Society of Civil Engineers, p. 568-582.

Harris, M. M., and Herbich, J. B., 1986, "Effects of Breakwater Spacing on Sand Entrapment," Journal of Hydraulic Research, Vol 24, No. 5, pp 347357.

Horikawa, K., Sasaki, T., and Sakuramoto, H., 1977, "Mathematical and Laboratory Models of Shoreline Changes due to Dredged Holes," Journal of the Faculty of Engineering, Vol XXXIV, No. 1, The University of Tokyo, Tokyo, Japan, pp 49-57.

Hubertz, J. M., and Brooks, R. M., 1989, "Gulf of Mexico Hindcast Wave Information," WIS Report 18, U.S. Army Engineer Waterways Experiment Station, Vicksburg, MS.

Inman, L. D., and Frautschy, J. D., 1966, "Littoral Processes and the Development of Shorelines," Proceedings, Coastal Engineering, Santa Barbara, CA, pp 511-536.

Japanese Ministry of Construction, 1986, "Handbook of Offshore Breakwater Design," River Bureau of the Ministry of Construction, Japanese Government, translated from Japanese for the Coastal Engineering Research Center.

Jensen, R. E., 1983, "Methodology for the Calculation of a Shallow-Water Wave Climate," WIS Report 8, U.S. Army Engineer Waterways Experiment Station, Vicksbury, MS.

Kraus, N. C., 1983, "Applications of a Shoreline Prediction Model," Proceedings Coastal Structures '83, American Society of Civil Engineers, pp 632-645.

Kraus, N. C., and Dean, J. L., 1987, "Longshore Sediment Transport Rate Distributions Measured by Trap," Proceedings Coastal Sediments '87, American Society of Civil Engineers, pp 881-896.

Kraus, N. C., and Harikai, S., 1983, "Numerical Model of the Shoreline Change at Oarai Beach," Coastal Engineering, Vol. 7, No. 1, pp 1-28. 
Louisiana Department of Natural Resources, Coastal Restoration Division, 1993, "Study of Breakwaters for Possible Construction at Grand Isle, Louisiana," prepared by HNTB under DNR Contract No. 25030-91-32.

McBride, R. A., Penland, Shea, Hiland M. W., Williams, S. J., Westphal, K. A., Jaffe, B. E., and Sallenger, A. H., Jr., 1992, "Analysis of barrier shoreline change Louisiana from 1853 to 1989, " in Williams, S. J., Penland, Shea, and Sallenger, A. H., Jr., eds., Louisiana barrier island erosion study atlas of barrier shoreline changes in Louisiana from 1853 to 1989: U.S. Geological Survey Miscellaneous Investigations Series I-2150-A, p. 36-97.

Meyer-Arendt, K. J., 1987, "Resort evaluation along the Gulf of Mexico littoral: Historical, morphological, and environmental aspects," Baton Rouge, Louisiana State University unpublished $\mathrm{Ph}$. D. dissertation, 92 p.

Nir, Y. 1982, "Offshore Artificial Structures and Their Influence on the Israel and Sinai Mediterranean Beaches," Proceedings 18th International Coastal Engineering Conference, American Society of Civil Engineers, pp 1837-1856.

Noble, R. M., 1978, "Coastal Structures' Effects on Shorelines," Proceedings 17th International Coastal Engineering Conference, American Society of Civil Engineers, pp 2069-2085.

Ozasa, H., and Brampton, A. H., 1980, "Mathematical Modeling of Beaches Backed by Seawalls," Coastal Engineering, Volume 4, No. 1, pp 47-64.

Pelnard-Considere, R., 1956, "Essai de Theorie de l'Evolution des Forms de Rivage en Plage de Sable at de Galets," 4th Journess de l'Hydraulique, Les Energies de la Mer, Question III, Rapport No. 1. pp 289-298.

Penland, Shea, Williams, S. J., Davis, D. W., Sallenger, A. H., Jr., and Groat, C. G., 1992, "Barrier island erosion and wetland loss in Louisiana," in Williams, S. J., Penland, Shea, and Sallenger, A. H., Jr., eds., Louisiana barrier island erosion study - atlas of barrier shoreline changes in Louisiana from 1853 to 1989: U.S. Geological Survey Miscellaneous Investigations Series 1-2150-A, p. 2-7.

Pope, J., and Dean, J. L., 1986, "Development of Design Criteria for Segmented Breakwaters," Proceedings 20th International Coastal Engineering Conference, American Society of Civil Engineers, pp 1930-1949.

Rosati, J. D., 1990, "Functional Design of Breakwaters For Shore Protection: Empirical Methods," Technical Report CERC-90-15, U.S. Army Engineer Waterways Experiment Station, Vicksburg, MS.

Rosati, J. D., and Truitt, C. L., 1990, "An Alternative Design Approach for Detached Breakwater Projects," Miscellaneous Paper in preparation, U.S. Army Engineer Waterways Experiment Station, Vicksburg, MS. 
Seiji, M., Uda, T., and Tanaka, S., 1987, "Statistical Study on the Effect and Stability of Detached Breakwaters," Coastal Engineering in Japan, Vol 30, No. 1, pp 131-141.

Shore Protection Manual. 1984, 4th Ed. 2 Vols, U.S. Army Engineer Waterways Experiment Station, Coastal Engineering Research Center, U.S. Government Printing Office, Washington, DC.

Suh, K., and Dalrymple, R. A., 1987, "Offshore Breakwaters in Laboratory and Field," Journal, Waterway, Port, Coastal, and Ocean Engineering, Vol 113 No. 2, pp 105-121.

Toyoshima, O., 1972, Coastal Engineering for Practicing Engineers - Beach Erosion, Morikita Publishing Co., Tokyo, Japan. (English translation available through the Coastal Engineering Research Center, U.S. Army Engineer Waterways Experiment Station, Vicksburg, MS, for Chapter 8 on "Offshore Breakwaters," pp 227-317).

,1974, "Design of a Detached Breakwater System," Proceedings 14th International Conference on Coastal Engineering, American Society of Civil Engineers, pp 1419-1431.

U.S. Army Corps of Engineers, 1979, "Grand Isle and vicinity Louisiana: Phase 1 General Design Memorandum," New Orleans District.

Williams, S. J., Penland, Shea, and Sallenger, A. H., Jr., editors, 1992, Louisiana barrier island erosion study - atlas of barrier shoreline changes in Louisiana from 1853 to 1989, U.S. Geological Survey Miscellaneous Investigations Series I-2150-A, 103 p. 
Public reporting burden for this collection of information is estimated to average $t$ hour per response, including the time for reviewing instructions, searching existing data sources. gathering and maintaining the data needed, and completing and reviewing the collection of information. Send comments regarding this burden estimate or any other aspect of this ( Dovis Highway, Suite 1204, Arlington, VA 22202-4302, and to the Office of Management and Budget, Paperwork Reduction Project (0704-0 188), Washington, OC 20503.

\begin{tabular}{|l|l|l|} 
1. AGENCY USE ONLY (Leave blank) & 2. REPORT DATE & 3. REPORT TYPE AND DATES COVERED
\end{tabular}

\begin{tabular}{|l|l|l|}
\hline & September 1994 & Final report \\
\hline
\end{tabular}

4. TITLE AND SUBTITLE

September 1994

Final report

Numerical Model Study of Breakwaters at Grand Isle, Louisiana

6. AUTHOR(S)

Mark B. Gravens, Julie Dean Rosati

7. PERFORMING ORGANIZATION NAME(S) AND ADDRESS(ES)

U.S. Army Engineer Waterways Experiment Station

3909 Halls Ferry Road

5. FUNDING NUMBERS

Vicksburg, MS 39180-6199

8. PERFORMING ORGANIZATION

REPORT NUMBER

Miscellaneous Paper

CERC-94-16

9. SPONSORING/MONITORING AGENCY NAME(S) AND ADDRESS(ES)

U.S. Army Engineer District, New Orleans

Foot of Prytania St., P.O. Box 60267

New Orleans, LA 70160-0267

11. SUPPLEMENTARY NOTES

Available from National Technical Information Service, 5285 Port Royal Road, Springfield, VA 22161.

12a. DISTRIBUTION / AVAILABILITY STATEMENT

Approved for public release; distribution is unlimited.

O. SPONSORING / MONITORING AGENCY REPORT NUMBER

13. ABSTRACT (Maximum 200 words)

This report presents the results of a numerical shoreline response investigation of a proposed segmented detached breakwater project offshore of Grand Isle, Louisiana. Functional shore protection characteristics of the recommended breakwater design alternative are further evaluated using empirical methods together with comparison to a recently constructed breakwater project between Holly Beach and Ocean View Beach in Cameron Parish, LA. The investigation involved the following three technical tasks: (a) conducting a nearshore wave transformation study, (b) numerical modeling of shoreline response, and (c) comparison of proposed breakwater design with empirical functional design guidance and similar projects.

Results of this investigation indicate good agreement between the numerically-generated (GENESIS) estimates of shoreline change in the vicinity of the proposed breakwater project at Grand Isle and the observed shoreline response at the Cameron Parish projects. Empirical relationships for functional breakwater design provided a relatively poor indication of actual beach response to breakwaters along the Louisiana coast. Because of the environmental similarities (mild beach slope, wave climate, tide range, etc.) between Grand Isle and Cameron Parish it is recommended that the Cameron Parish breakwater project together with the GENESIS results be used for designing the Grand Isle breakwater project.

\begin{tabular}{|c|c|c|c|}
\hline \multirow[t]{2}{*}{ 14. SUBJECT TERMS } & \multirow{2}{*}{$\begin{array}{l}\text { Beach erosion } \\
\text { Coastal processes } \\
\text { Detached breakwaters }\end{array}$} & \multirow{2}{*}{$\begin{array}{l}\text { Grand Isle } \\
\text { Louisiana } \\
\text { Shoreline change }\end{array}$} & $\begin{array}{l}\text { 15. NUMBER OF PAGES } \\
81\end{array}$ \\
\hline & & & 16. PRICE CODE \\
\hline $\begin{array}{l}\text { 17. SECURITY CLASSIFICATION } \\
\text { OF REPORT } \\
\text { UNCLASSIFIED }\end{array}$ & $\begin{array}{l}\text { 18. SECURITY CLASSIFICATION } \\
\text { OF THIS PAGE } \\
\text { UNCLASSIFIED }\end{array}$ & $\begin{array}{l}\text { 19. SECURITY CLASSIFICATION } \\
\text { OF ABSTRACT }\end{array}$ & 20. LIMITATION OF ABSTRACT \\
\hline
\end{tabular}

